\title{
Recycling and environmental issues of lithium-ion batteries: advances, challenges and opportunities
}

C. M. $\operatorname{Costa}^{1,2, *}$, J. C. Barbosa ${ }^{1,3}$, R. Gonçalves ${ }^{2}$, H. Castro ${ }^{1,4}$, F. J. Del Campo ${ }^{5,6}$,

S. Lanceros-Mendez ${ }^{5,6}$

${ }^{1}$ Centre of Physics, University of Minho, 4710-057 Braga, Portugal

${ }^{2}$ Centre of Chemistry, University of Minho, 4710-057 Braga, Portugal

${ }^{3}$ Institute of Science and Innovation for Bio-Sustainability (IB-S), University of Minho, 4710-053 Braga, Portugal

${ }^{4}$ Instituto de Soldadura e Qualidade, Rua Mirante 258, 4415-491 Grijó, Portugal

${ }^{5}$ BCMaterials, Basque Centre for Materials, Applications and Nanostructures, UPV/EHU Science Park, 48940 Leioa, Spain.

${ }^{6}$ IKERBASQUE, Basque Foundation for Science, 48009 Bilbao, Spain

\begin{abstract}
Lithium-ion batteries, LIBs, are an essential part of our daily lives. They may seem unnoticed, but they are ubiquitous through mobile phones, tablets, laptop computers and many other consumer electronic devices. Their demand has strongly increased in recent years, and it is expected to further grow, driven by the increase of electric vehicles. This increase in the demand for LIBs also brings environmental issues related to the mining, extraction and purification of scarce materials such as cobalt, nickel and lithium.

This work provides an overview on the relevance of recycling LIBs and their environmental impact. It also analyses the components of LIBs and evaluates their value in the world market. Although there is a strong focus on lithium, other critical metals, such as cobalt and nickel, are also addressed.

Different recycling methods for the different battery components are reported together with the main achievements. The advantages and disadvantages of the different used methods are discussed, and their environmental issues are considered. Finally, the main environmental issues associated with the production, use and end of life of LIBs for electric vehicles are described.
\end{abstract}


Keywords: Lithium-ion batteries; metals; recycling methods; environmental issues

\section{Table of Contents}

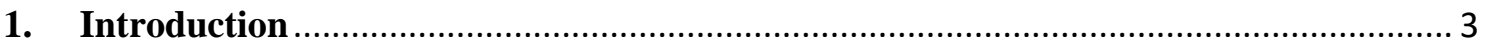

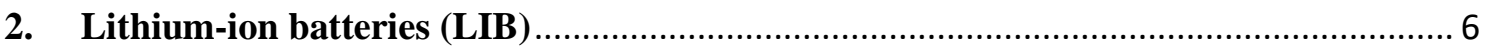

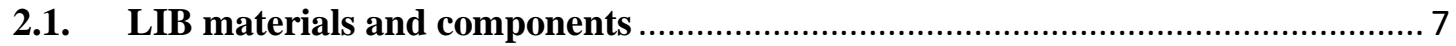

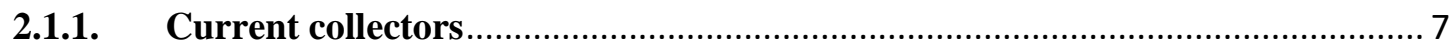

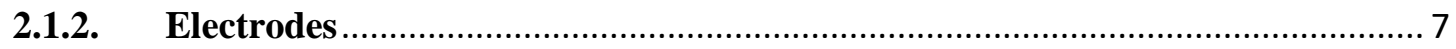

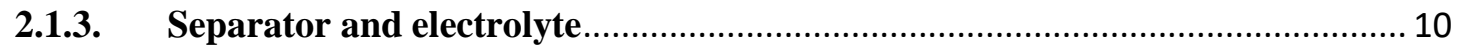

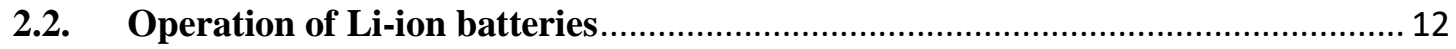

2.3. Market demand, natural resources, and LIB production costs .......................... 13

2.3.1. Lithium sources …………............................................................................. 15

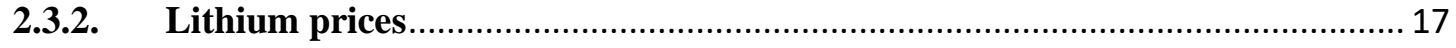

2.3.3. The cost of LIB manufacturing ....................................................................... 17

3. Lithium-ion batteries: Environmental issues and recycling strategies ....................... 21

3.1. Environmental impact of LIBs..................................................................... 21

3.2. Recycling strategies: direct recycling, pyro- and hydrometallurgical processes. 27

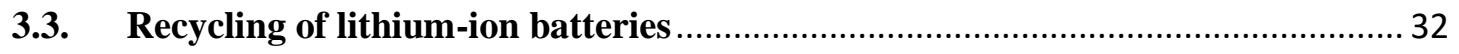

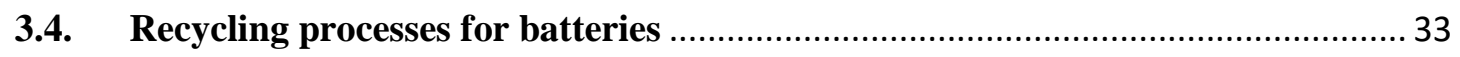

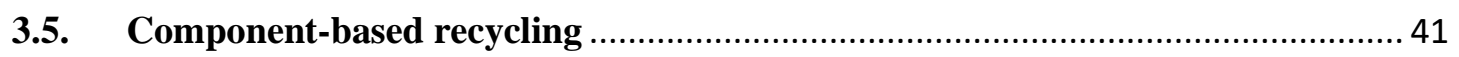

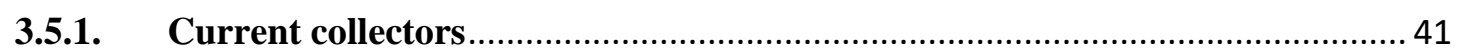

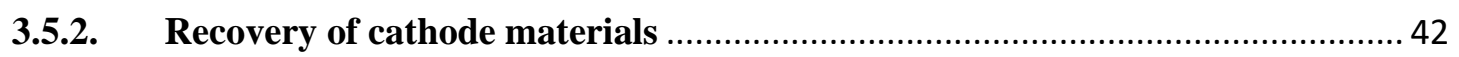

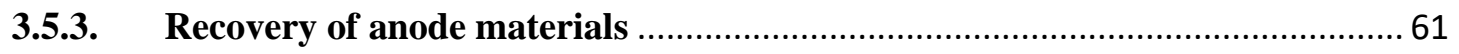

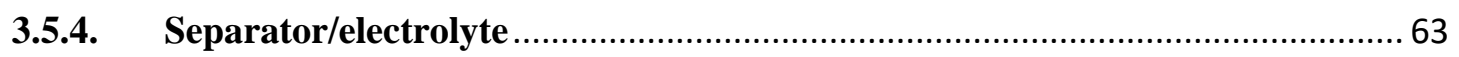

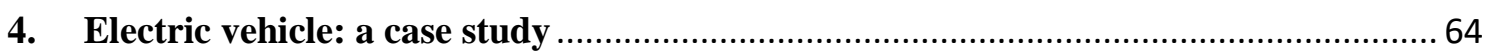

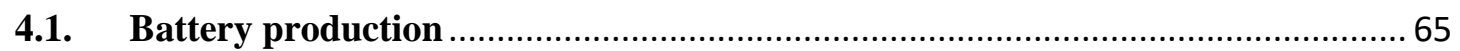

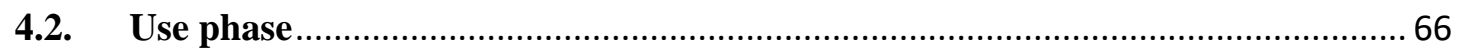

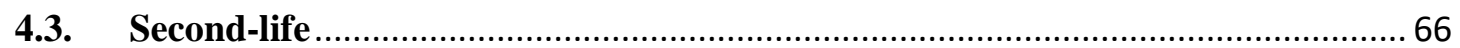

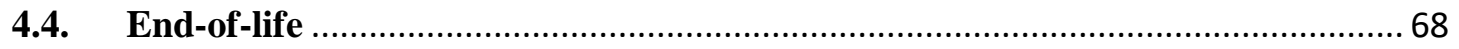

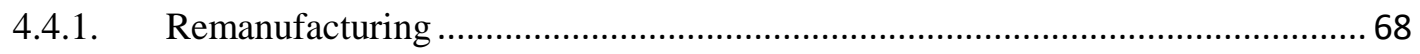

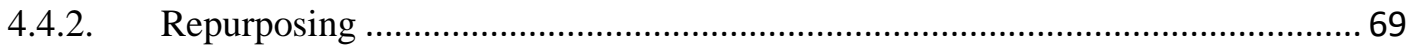

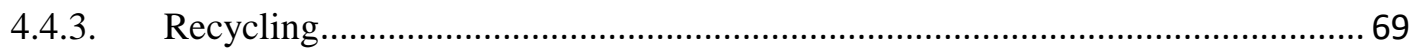

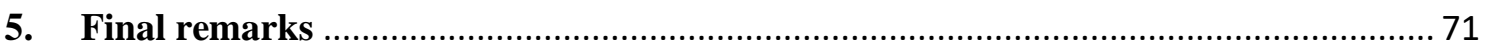




\section{Introduction}

The demand for lithium-ion batteries, LIBs, has grown very significantly over the last ten years, driven by consumer electronics. Today there are 7.19 billion active mobile phones [1], close to 1 billion laptop computers, and another billion tablets worldwide [2]. This demand for LIBs from the consumer electronics sector not only will remain high, but it will increase even more due to the increasingly relevant concept of energetic transition, that will lead to the shift from fossil fuels based mobility towards the electric vehicle, EV, in the automotive industry [3].

In order to get a better understanding of the dynamics of this demand, regarding both the producers and the consumers, a couple of studies were carried out recently. A trade-linked material flow analysis framework was developed to study the lithium flow over its life cycle, both at a national and international levels [4]. China, Chile and Australia are the leaders in lithium extraction, which is mainly used in the production of batteries for consumer electronics. China is also the main importer of lithium materials, that are mostly traded in the form of ores, carbonates and concentrates [4]. The Chinese lithium industry has contributed significantly to the recent increase in LIB production. It relies on the imports of lithium minerals that are processed and transformed into final products, essentially batteries for a large variety of devices, such as smartphones, laptops and electric vehicles, and which are then exported across the world [5]. It was estimated [6] that 0.5 million tonnes of lithium-based materials have been produced in China during 2020 .

This situation calls for adequate lithium re-use and recovery strategies to be implemented soon, or lithium and cobalt reserves, to name perhaps the scarcest of the metals involved in the production of LIBs, will be significantly reduced [7, 8]. Meanwhile, important environmental damage will occur as a result of LIB production and disposal. In these damages are included ecosystems destruction during mining, and highly polluting activities related to metal extraction and LIB production [9]. Later, LIB disposal, which often occurs together with the electronic devices that they have powered, is not only polluting, due to the heavy metals present, but also economically wasteful, as most of those highly valuable materials could be recovered and reused [10]. For example, mobile phones have a replacement rate between 12 and 18 months, regardless of their actual condition. Less than four years ago, the recycling rate for LIBs from mobile phones was 
below 5\% [10]. This figure may have gone up a bit today, but it likely remains below $10 \%[11,12]$.

Lithium-battery recycling can help to preserve the environment, save resources, reduce the volume of waste, and also bring economic benefits [13]. Lithium, cobalt and nickel are critical to the operation of LIBs, but they are also relatively scarce. Thus, it is necessary to develop practices and governance strategies that allow sustainable exploitation of their natural resources, as well as efficient recycling processes that will allow the reduction of the pressure on the natural resources. Despite this urgent need and its benefits, recycling effectively is a very challenging task. Interventions for more sustainable exploitation in the context of suppliers and consumers are possible. Producers should focus on the development of mechanisms for the long-term production and materials efficiency of these metals. At the same time, consumers should be educated to support the circular economy concept, seeking high recycling rates [14].

LIB recycling presents large advantages in natural resources savings. It is estimated that recycling can save up to $51 \%$ of the extracted natural resources, including the reduction in the use of fossil fuels and nuclear energy necessary in the extraction and production processes [15]. However, achieving full independence from virgin resources seems impossible, because in a constantly growing market, the available recycled resources are always less than the demand [15].

LIB recycling will not be a reality unless it is economically viable. Most of the valuable materials in a LIB are in the cathode, which is the last component to be removed in the disassembly process [16], increasing the cost of its recovery, due to the different disassembling process steps that must be taken to recover it. However, each manufacturer produces different types of devices, using different materials, shapes, morphologies and proportions, leading to the necessity of a vast recovery infrastructure, capable of responding to these differences $[17,18]$. There are also limitations in the recycling processes because of the lack of implementation of good environmental practices. For example, many people do not remove the batteries from spent devices when it is time to discard them, preventing any chance of recovery [19].

This review focuses on LIB materials all along the different stages of their lifecycle. The scarcity of materials and their prices with a particular focus on lithium are discussed. A comprehensive review of the current state-of-the-art in the recycling processes of LIBs is thus presented. The latest developments and the proposed processes are reported, as well as the main advantages and disadvantages of each one. The processes' efficiencies are 
also presented, together with an analysis of the current situation of lithium resources as well as information on other materials relevant in battery manufacturing.

This paper addresses in a clear and objective way the economic and environmental benefits that can be brought by the recycling of LIBs. This question gains even more relevance in relation to the area of electric mobility, where it will have significantly large impact. The main focus on cathode materials is due to their high relevance and value, and also because of the difficulty to effectively recycle their components, making it the most widely studied battery component. The necessity of standardizing battery materials and their conformation, as well as the need to apply legislation to incentive the battery recycling are also approached. 


\section{Lithium-ion batteries (LIB)}

Secondary batteries can be defined as reversible systems that turn their stored chemical energy into electricity to power an external circuit during their discharge phase. During the charge phase, the cell is connected to an external energy source, and the electrode processes are reversed [20]. In particular, LIBs rely in lithium ions during the charge/discharge processes. Each cell has four main components: anode, cathode, separator and electrolyte. This section reports on lithium and other important battery materials in the world market and describes the construction and working principles of a LIB cell, focusing on its evolution from a materials perspective.

Lithium was first discovered in the minerals petalite $\left(\mathrm{LiAlSi}_{4} \mathrm{O}_{10}\right)$ and spodumene ( $\mathrm{LiAlSi}_{2} \mathrm{O}_{6}$ ) around 1817 by Swedish chemist Johan Arfwedson, and Berzelius named it after lithos, the Greek word for stone. Pure metallic lithium was first obtained in 1821 by the English chemist William Thomas Brande, by electrolysis of lithium oxide. Metallic lithium was eventually (1923) industrially produced (Metallgesellschaft AG) by electrolysis from a mix of lithium chloride (55\%) and potassium chloride (45\%), using a method discovered by Robert Bunsen and Augustus Matthiessen in 1855.

Lithium metal possesses a characteristic silver-white colour that tarnishes when exposed to the air, due to its high reactivity with oxygen. Metallic lithium should be stored under anhydrous atmosphere, mineral oil or vacuum-sealed. Due to this high reactivity, the natural forms of lithium are brines, rock minerals and salts. Lithium can also be found in river waters, surface waters, groundwaters and lakes where, depending on local geology and topography, its concentration is between 0.070 and $40 \mu \mathrm{g} \cdot \mathrm{L}^{-1}$ at the surface and between 170 and $190 \mu \mathrm{g} . \mathrm{L}^{-1}$ in seawater, being the fourteenth most abundant element in the seawater. In soils, this element is also found in trace amounts with an average of 3$350 \mathrm{mg} \cdot \mathrm{kg}^{-1}$, also depending on local geology and topography [21].

Lithium is the most electropositive metal, with a potential of $3.045 \mathrm{~V}$ (vs the standard hydrogen electrode, SHE), it has an energy density of $3860 \mathrm{mAh} \cdot \mathrm{g}^{-1}$, and is the least dense $\left(\rho=0.534\right.$ g.cm $\left.{ }^{3}\right)$ and lightest $\left(A_{r}=6.94\right.$ g.mol $\left.{ }^{-1}\right)$ metal [22]. Its melting temperature is $180.5^{\circ} \mathrm{C}$, and has a specific heat capacity of $3.56 \mathrm{~J}^{-1} \mathrm{~g}^{-1} \cdot \mathrm{K}^{-1}$ at $25^{\circ} \mathrm{C}$. When compared with other metals, all these properties make lithium the most characteristic and important element for energy storage today, as it is proven by its wide use in batteries [23].

Lithium is also important in other applications, including medicine and metallurgy. For instance, the chemical industry uses it to decrease the viscosity of glass and ceramic [24], 
as desiccants for gas streams [25], to strength alloys [26], as base and nucleophile (organolithium) [27] and as a lubricant in automotive applications [28]. In medicine, lithium is used in the treatment of bipolar disorder [29], depression ${ }^{[30]}$, dental ${ }^{[31]}$ and headaches [32].

Regarding LIBs, they were first commercialised by Sony and Asahi Kasei in 1991, once the dendrite formation (lithium formations that grow in anode electrode interface during the charge/discharge process) problems had been solved [33]. Nowadays, most portable electronic devices, such as laptops, smartphones and pacemakers, and devices such as electric vehicles and power walls use LIBs to store and supply energy.

\subsection{LIB materials and components}

As stated before, a LIB is composed by two electrodes, a separator and an electrolyte system. The electrodes (anode and cathode) typically consist of a mixture of three components in contact with a current collector foil. These three components are a conductive material (CM), an active material (AM) and a binder solution (BS). These three components are mixed into a paste that coats the electrode side of the current collector. While anode and cathode use different active materials, the binder solution system is usually shared. The separator is a porous membrane, typically soaked in an ionic conductive electrolyte solution, that avoids physical contact between the electrodes.

\subsubsection{Current collectors}

Current collectors support the electrode materials and guarantee the passage of electrons through the external circuit. The current collector should provide high mechanical stability, high electron conductivity, high chemical stability (excellent corrosion resistance) and low weight and thickness [34]. Copper and aluminium are typical anode and cathode current collector materials, respectively, due to their electronic conductivity and stability [35]. Different surface treatments such as plasma treatment [36], and coatings as carbon [37], vanadium oxide [38], among others, can be applied to further enhance the current collector properties (such as electric conductivity and surface chemistry).

\subsubsection{Electrodes}

With respect to the electrode composition, the AM:CM:BS ratio and materials affects cell performance. The proportion between these components directly affects ionic 
conductivity, porosity and conductivity, among other properties [39]. Different ratios between the AM:CM:BS have been reported [40]. Higher BS/CM ratios increase the interfacial resistance [41]. Higher AM proportions at the cathode lead to higher battery capacities, while at the anode ensure the lithium-ion storage capacity [42]. Thus, typical cathode compositions contain AM proportions in the range between 60 and 95\%, CM around 2 to $25 \%$ and BS around 3 to $30 \%$ [42].

In a cathode with poly(vinylidene fluoride), PVDF, as a binder, a ratio of PVDF:CM of 5:4 allows to increase the rate capability of the electrode, decreasing the AM content down to around $80 \%$. The ion-blocking effect of PVDF and the electronic conductivity of the CM (being carbon-black the most used) compete with the AM for the battery capacity [43].

The active material in LIBs is thus responsible for lithium intercalation and reservoir. Table 1 summarises the most common active materials used in LIBs, which are mainly lithium metal oxides and phosphates such as lithium cobalt oxide $\left(\mathrm{LiCoO}_{2}-\mathrm{LCO}\right)$, lithium iron phosphate $\left(\mathrm{LiFePO}_{4}-\mathrm{LFP}\right)$, lithium manganese oxide $\left(\mathrm{LiMn}_{2} \mathrm{O}_{4}-\mathrm{LMO}\right)$, lithium nickel manganese cobalt oxide ( $\left.\mathrm{LiNiMnCoO}_{2}-\mathrm{NMC}\right)$ and lithium nickel cobalt aluminium oxide $\left(\mathrm{LiNiCoAlO}_{2}\right.$ - NCA). The most common active anode materials are graphite and silicon. The final application dictates the necessary voltage and charge capacity, which determines the selection of active material for each electrode.

Table 1 - Anode and cathode active materials with theoretical voltage and specific capacity, lithium precursor and synthesis method.

\begin{tabular}{|c|c|c|c|c|c|c|}
\hline & Active material & $\begin{array}{l}\text { Theoretical } \\
\text { voltage }(\mathbf{V})\end{array}$ & $\begin{array}{c}\text { Theoretical } \\
\text { specific } \\
\text { capacity } \\
\left(\mathrm{mAh} . \mathrm{g}^{-1}\right) \\
\end{array}$ & $\begin{array}{l}\text { Lithium } \\
\text { precursor }\end{array}$ & $\begin{array}{l}\text { Synthesis } \\
\text { method }\end{array}$ & Ref \\
\hline \multirow{5}{*}{ Cathode } & $\mathrm{LiCoO}_{2}$ & 3.8 & 274 & $\mathrm{LiOH} . \mathrm{H}_{2} \mathrm{O}$ & solid-state & [44] \\
\hline & $\mathrm{LiFePO}_{4}$ & 3.4 & 170 & $\mathrm{Li}_{2} \mathrm{CO}_{3}$ & solid-state & [45] \\
\hline & $\mathrm{LiMnO}_{2}$ & 3.3 & 285 & $\mathrm{LiBr}$ & solid-state & [46] \\
\hline & $\mathrm{LiNi}_{0.33} \mathrm{Mn}_{0.33} \mathrm{Co}_{0.33} \mathrm{O}_{2}$ & 3.7 & 280 & LiOH. $\mathrm{H}_{2} \mathrm{O}$ & $\begin{array}{c}\text { Co- } \\
\text { precipitation }\end{array}$ & {$[47]$} \\
\hline & $\mathrm{LiNi}_{0.8} \mathrm{Co}_{0.15} \mathrm{Al}_{0.05} \mathrm{O}_{2}$ & 3.7 & 279 & $\mathrm{LiOH} . \mathrm{H}_{2} \mathrm{O}$ & $\begin{array}{l}\text { Co- } \\
\text { precipitation } \\
\text { and solid- } \\
\text { state }\end{array}$ & [48] \\
\hline Anode & Graphite & 0.2 & 372 & & Natural & [49] \\
\hline
\end{tabular}


Carbon black is the most common conductive material used in LIBs [51]. It keeps the electrical contact between the active material particles and the current collector. Also, thanks to its high electrical conductivity and large surface area, it decreases the electrode polarisation potential and improves the cycle life of the battery [52].

Finally, the binder material provides mechanical support to the electrode structure through the bonding of the AM and CM and the adhesion to the current collectors. However, it should be also electrochemically inert and allow ionic conduction [53]. Despite its low content in the electrode (between 2 and 5\%), and its chemical inertness, the binder plays an essential role with respect to electrode performance. The binder must also ensure easy processability during electrode manufacture, display low electrolyte swelling, and should be economic and environmentally friendly.

PVDF and copolymers, [54] and polypropylene (PP) [55] are the most common binders used in LIB production. The binder system also includes solvents that facilitate mixing of the binder resin together with the AM and CM. However, the solvents commonly used due to their good solubility properties ${ }^{[37]}$, such as N-methyl-2-pyrrolidone (NMP) or N $\mathrm{N}$-Dimethylformamide (DMF), tend to be toxic and teratogenic. Greener alternatives (such as water) should be explored to improve processing and reduce the environmental footprint of the production process. As shown in Figure 1, the use of water instead of NMP, for example, brings important benefits (less energy consumption and equipment, reduction of the industrial wastes) by also modifying the manufacturing processes during the electrode production. The exclusion of some steps, such as ventilation, controlled environment and solvent recovery systems, are some examples of the positive effect in this change ${ }^{[53]}$. Processability, safety, and availability in nature are some of the selection criteria for alternative new green solvents. In this scope, water-based electrode manufacturing routes could provide both improved safety and more sustainable and environmentally friendly electrochemical energy storage devices [56]. 


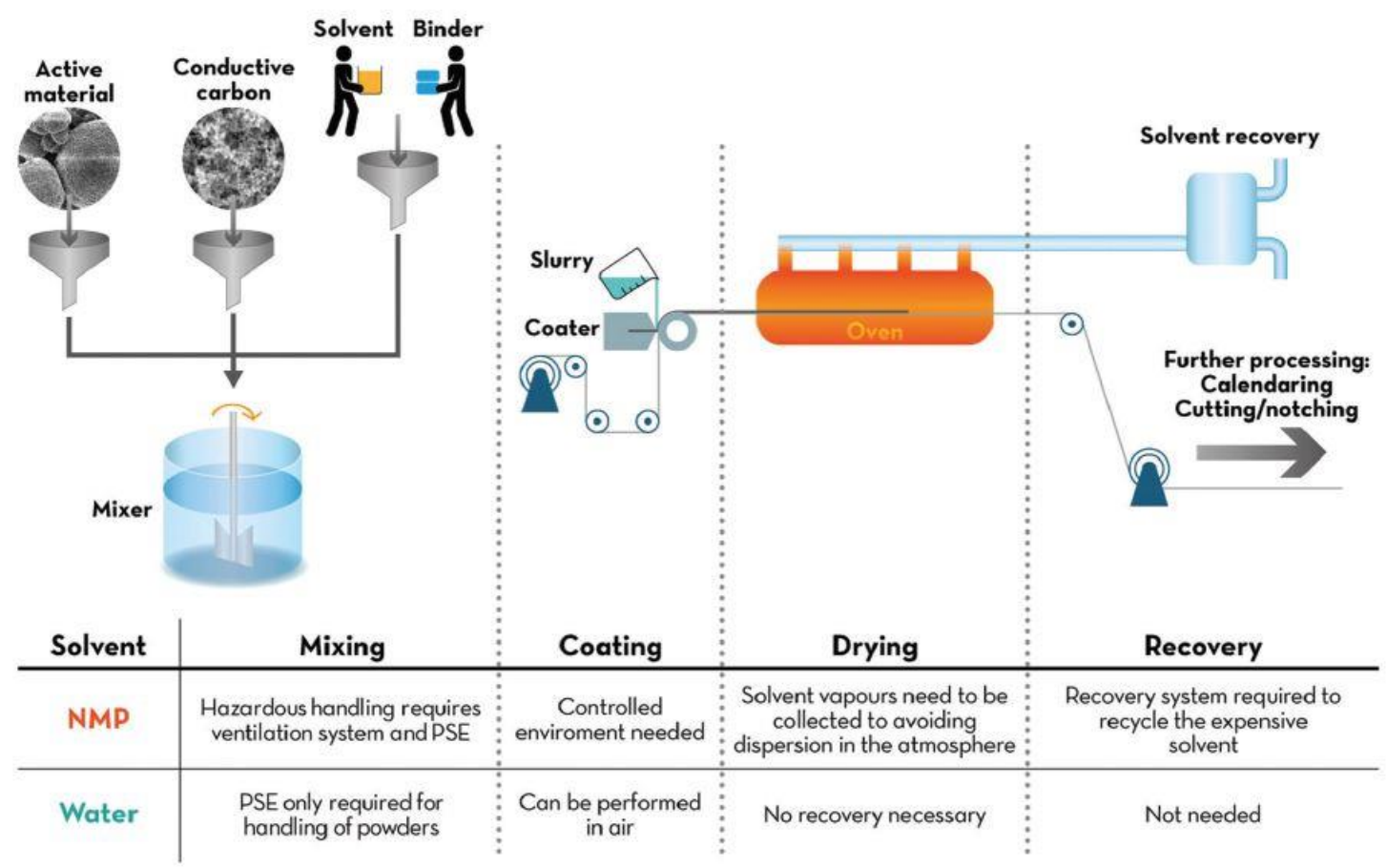

Figure 1 - Schematic representation of the battery electrode manufacturing process showing the advantages of using water vs NMP as the primary solvent for each step. PSE means pressurized solvent extraction [56].

\subsubsection{Separator and electrolyte}

The purpose of the separator is to increase cell safety by preventing short circuits between anode and cathode. The main requirements of the separator are: a) high ionic conductivity, b) uniform porous structure, c) good wettability, c) excellent chemical stability (between the separator and the electrolyte at working voltage and temperature), d) low thickness e) limited shrinkage and f) low electric conductivity [57].

Each separator/electrolyte system has different compositions and properties, depending on the application. The most common systems involve porous membranes, typically based on non-woven materials soaked in a liquid electrolyte. However, due to the difficulty to fabricate nonwoven fabrics thinner than $25 \mu \mathrm{m}$, other polymeric separator types have also been widely studied [58].

Commercial separators are based on microporous polyolefin membranes, such as polypropylene (PP) [59] and polyethylene (PE) [55], and in fluorinated polymers, as PVDF and its copolymers [60]. Studies in this field are focussing on improving porosity [61], wettability [62], thermal stability [63] and ionic conductivity; sometimes by using ionic liquids [64], polymers [63] and particles addition [65], among others. More 
environmentally benign separators, that avoid the use of synthetic polymers, are being investigated based on natural polymers and materials such as cellulose [66] or silk [67], among others, or even recycled polymers. These polymers have the advantage of reducing the produced residues [68]. Another subject of increasing interest is the use of solid-state electrolytes to avoid the use of liquid electrolytes [69]. Solid state electrolytes include solid polymer electrolytes and inorganic solid electrolytes, the main difference being the use of a polymer or an inorganic material as matrix. Gel polymer electrolytes combine both the characteristics of the solid and the conventional electrolytes (Figure 2) [70]. These materials could avoid safety and performance problems related to thermal shrinkage and low ionic conductivity (five orders of magnitude lower) of the conventional separators without electrolyte [71].

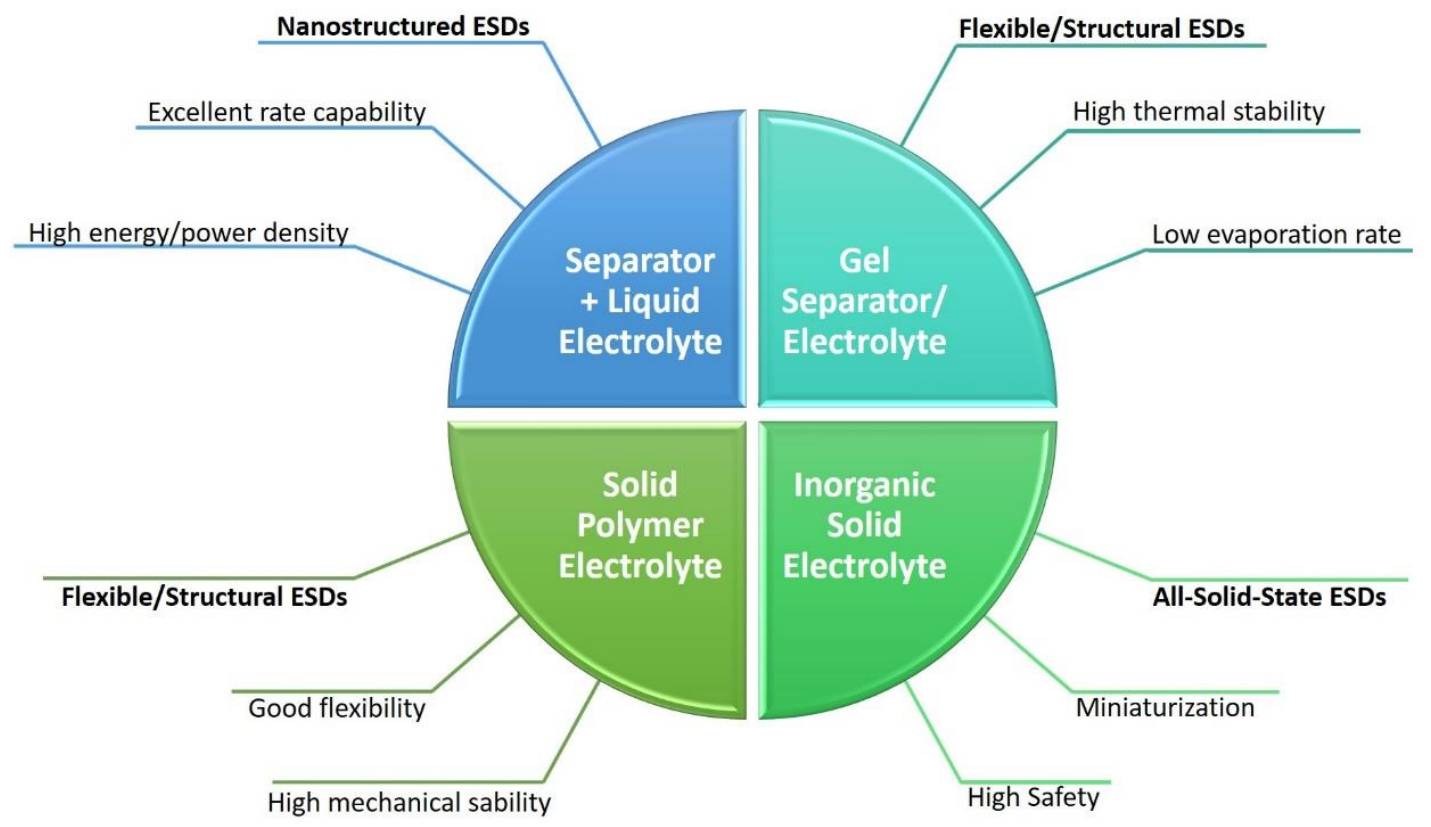

Figure 2 - Different separator/electrolyte in future ESDs. Based on [70].

The selection of the electrolyte is essential because the reactions that occur at the electrode/electrolyte interface are determinant in battery performance. The ideal electrolyte should be environmentally friendly and easy to process, but also cost-effective and must enable excellent battery performance. Thus, the ideal electrolyte must possess wide electrochemical window, low viscosity, good wettability towards separator and electrode, high flash point and, more importantly, high ionic conductivity [72]. The selection of a particular electrolyte system also depends on the final application [70], but it also needs to be compatible with the electrode materials and the fabrication process. 
The electrolyte is typically a high-grade lithium salt, such as lithium hexafluorophosphate $\left(\mathrm{LiPF}_{6}\right)$, lithium tetrafluoroborate $\left(\mathrm{LiBF}_{4}\right)$, lithium bis(trifluoromethanesulfonyl)imide) (LiTFSI), or others, dissolved in dipolar aprotic organic alkyl carbonate solvents, such as ethylene carbonate / dimethyl carbonate (EC/DMC). The reactions of the electrolyte during battery operation can lead to the undesirable formation of a layer (solid electrolyte interface - SEI) that can decompose the electrode. The addition of fluoroethylene carbonate [73] and other additives [74] have been proposed to prevent this degradation.

\subsection{Operation of Li-ion batteries}

Figure 3 shows a schematic representation of a LIB cell and its operation principle. Inside the cell, during the spontaneous redox reaction (discharge), lithium-ions move from the anode (negative electrode), across the electrolyte, towards the cathode (positive electrode), which is reduced [75]. Lithium-ion transport is reversed during the charge process, and ions travel from the cathode to the anode. Note that electrons travel through the external circuit in the same direction as lithium-ions do inside the cell to maintain the charge balance. Electrons leave the electrode active material through the current collector (highly conducting metal) to reach the external circuit [35].

To ensure that electrons exit the cell, the separator, a microporous membrane sandwiched between anode and cathode, prevents short-circuiting of the electrodes. The separator also allows the exchange of lithium-ions through it. The electrolyte, which fills the separator and comes in touch with the electrodes, ensures the ionic conductivity and mobility not only between the electrodes but also inside the electrodes [76]. 


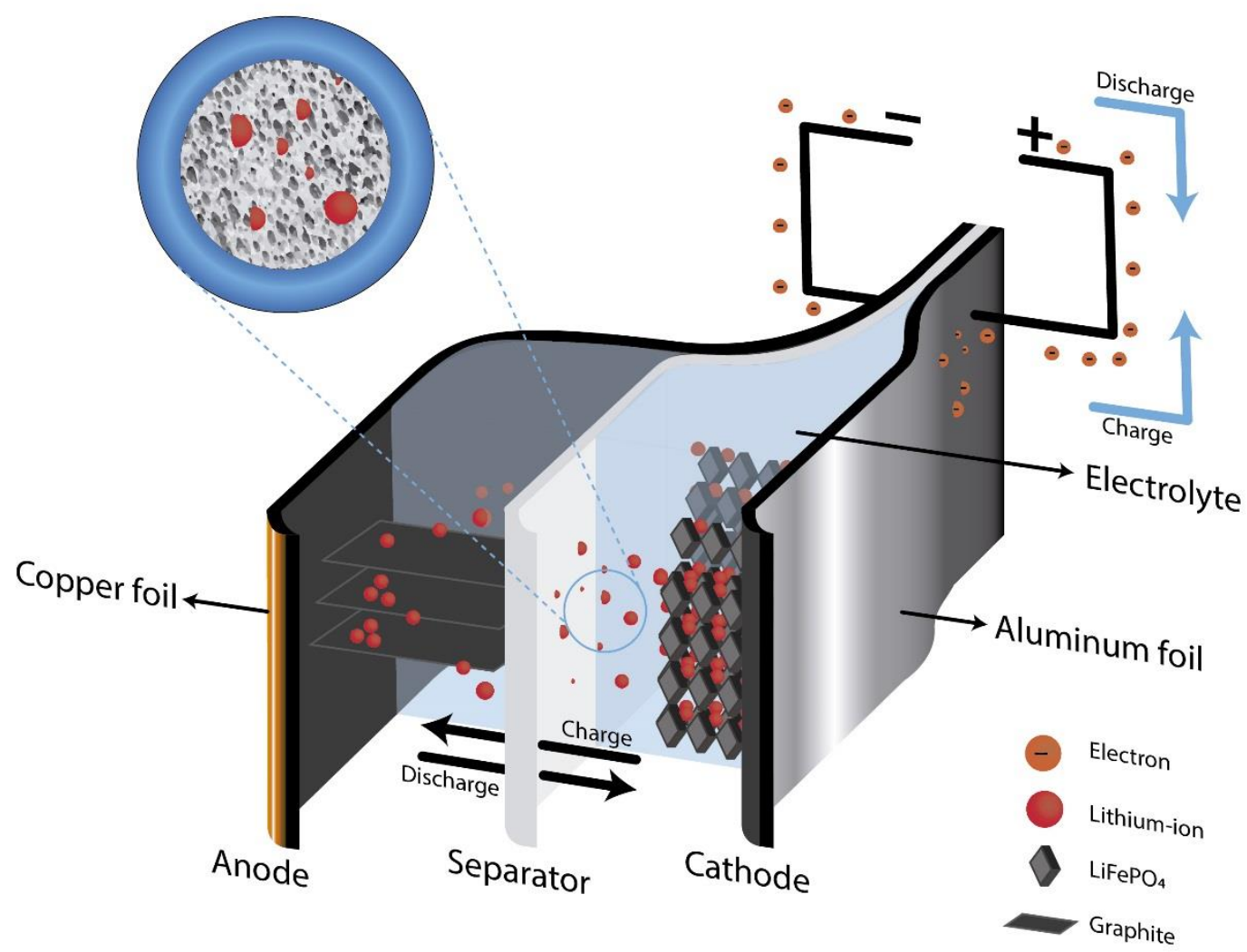

Figure 3 - LIBs components, charge and discharge process and lithium-ion movement in LIBs.

\subsection{Market demand, natural resources, and LIB production costs}

Nowadays lithium is more than just another metal used in different markets. Lithium is considered a key material to replace fossil fuels and hence as part of the solution to the important issue of climate change. The application of LIBs in electric vehicles and other renewable energy storage systems will lower the consumption of fossil fuels [77]. Lithium end-use consumption has strongly increased over the last years. In 2015 the two main end-use markets of lithium were batteries (35\%) and glass and ceramics (32\%) [78]. As Figure 4 shows, the worldwide lithium battery market rose to $65 \%$, while that for ceramics and glass decreased to $18 \%$ [79]. 


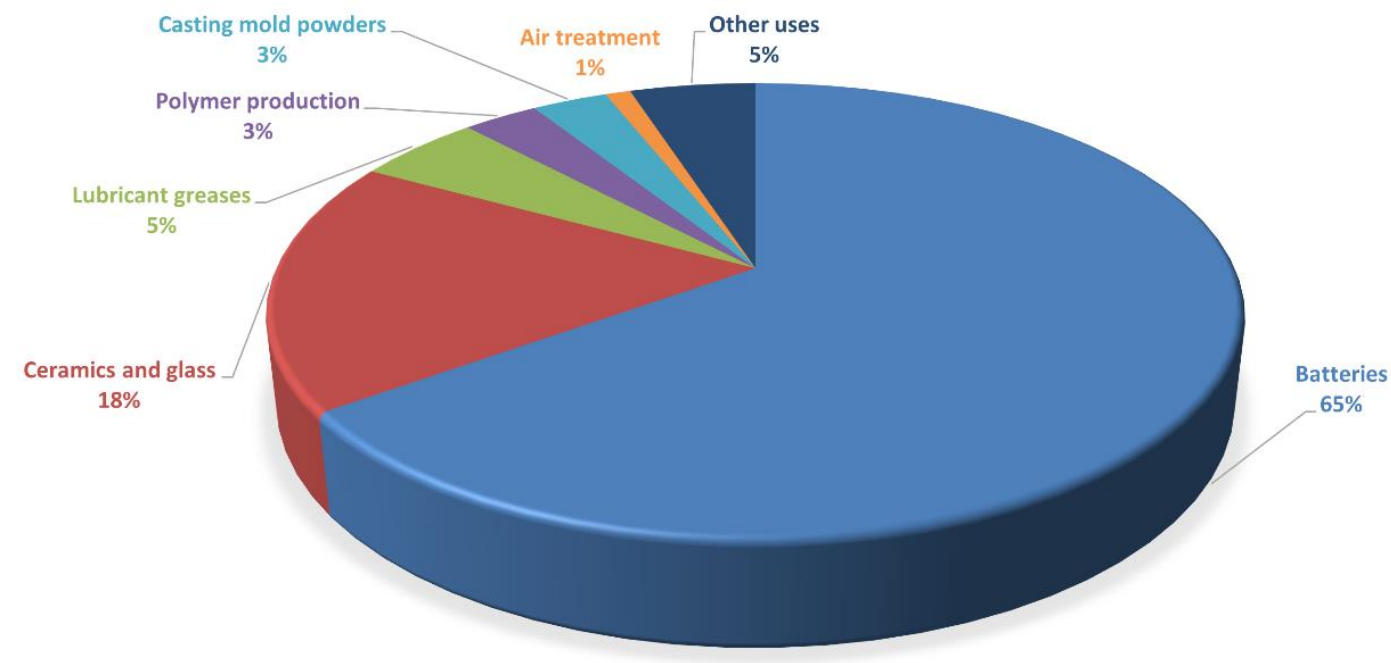

Figure 4 - Global lithium end-use market shares. Source: US Geological Survey 2019.

To framework this increase in the use of lithium in energy applications, note that the global energy market is estimated to be worth 250 billion $€$ by 2025 . As previously mentioned, the surge in consumer electronics and the Internet of Things (IoT) are driving an increasing demand for lithium in the form of LIBs. Figure 5 forecasts that both supply and demand will continue to grow in the near future. This increase in demand resulted in a $61 \%$ price rise for battery-grade carbonate, only in 2016-2017 [80]. However, if the forecast is correct, the price of lithium carbonate and lithium hydroxide may decrease

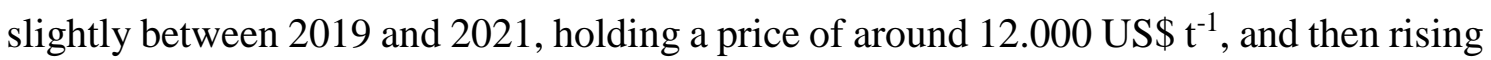
again until 2025. According to the Benchmark Mineral Intelligence Agency, the peak in the lithium price observed in 2018 was due to the approaching end of Chinese subsidies to the EV. Those subsidies resulted in higher lithium demand and production. The following price relaxation is due to the de-stocking of excess supply, also resulting from the end of subsidies. Beyond that, it will increase recoverable lithium resources [81]. 


\section{Lithium Supply/Demand and Pricing}

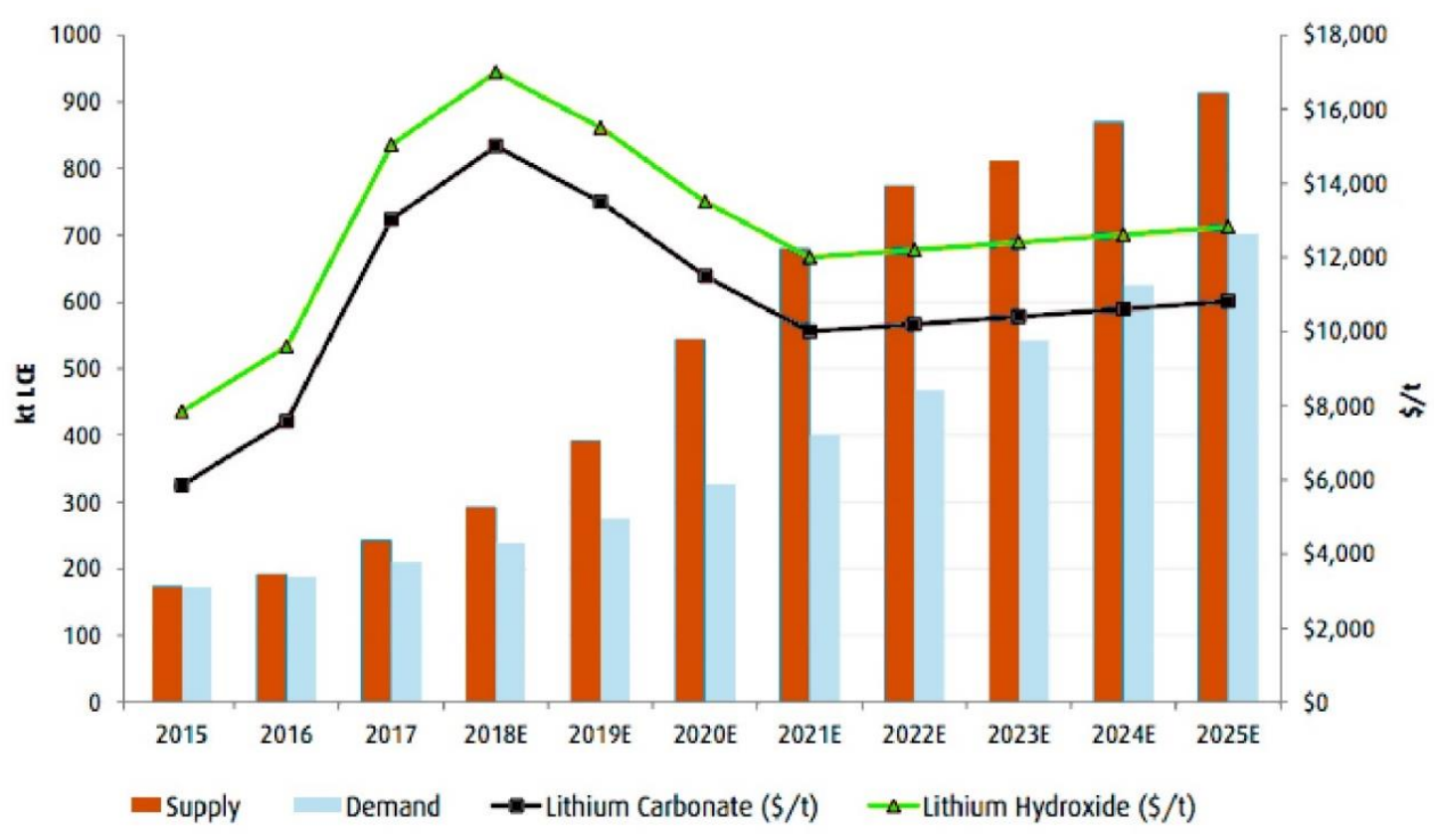

Figure 5 - Estimated world lithium consumption and production (excluding U.S. production)[80].

\subsubsection{Lithium sources}

As stated before, lithium can be found in brines and hard rock, complex aluminium silicate deposits - pegmatites. Pegmatites are intrusive igneous rocks that contain lithium. Typical examples are spodumene, petalite, amblygonite, lepidolite, eucryptite, triphylite and zinnwaldite. Lithium is also present in quartz, mica and feldspar [23]. From an economic viewpoint, spodumene is the most important pegmatite due to its high lithium content $\left(8 \%, \mathrm{Li}_{2} \mathrm{O}\right)$ and its relative abundance in extensive deposits (spodumene is found in more than 8 countries). Table 2 summarises the total world lithium reserves (brines and ores) by country. All these countries have increased the mine production of lithium since 2017, but Australia is the leading overall producer, with 42.000 tons of lithium in 2019. This is roughly $55 \%$ of the world output.

On the other hand, Chile holds the largest lithium reserves, containing roughly 8.6M tons. Other countries, such as Bolivia, Canada and Namibia, also possess a large amount of lithium resources, however they are not being explored nowadays, despite the fact that there are projects to develop mining operations there [82]. Looking at the total world reserves and considering the present production and expected demand growth, there 
seems to be plenty of lithium for the next hundred years. However, it has been forecast that lithium demand may soon exceed its supply in a scenario in which not even recycling processes will stop this trend [83]. Other studies conclude that, by 2050, the cumulative demand for lithium will range between 74 and $248 \%$ of the reserves, while the cobalt cumulative demand will be $50 \%$ of its reserves [83]. The variability in these predictions probably originates in the uncertainties underpinning the assumptions made to venture them.

Moreover, cobalt and nickel will present supply problems well ahead of lithium. It is also reasonable to believe that, by then, alternative, cleaner, and more efficient energy sources will have been developed [84]. However, if dependence on LIBs lasts very long, the environmental damage derived from extraction and processing of lithium and other (rarer) metals can be so extensive that environment protection reasons should be enough to encourage recycling policies and measures worldwide.

Figure 6 shows the worldwide distribution of lithium reserves and mining explorations, as well as the primary trade flux between the producer and consumer countries. This trade flux is the main driver of the worldwide lithium prices, which are dependent of various factors, such as the location of the lithium source (that affects the labour costs for example), and the type of mining operation (hard rocks are usually more expensive than brines).

Table 2 - Lithium reserves and production. Australia is the leading producer, but Chile has the largest reserves [82]. ${ }^{\mathrm{a}}$ Estimated; ${ }^{\mathrm{b}}$ For Australia Joint Ore Reserves Committeecompliant reserves were about 1.7 million tons.

\begin{tabular}{|c|c|c|c|}
\hline Country & \multicolumn{2}{|c|}{ Mine production (tons) } & Reserves (tons) \\
\hline Chile & $\mathbf{2 0 1 8}$ & $\mathbf{2 0 1 9}^{\mathbf{a}}$ & \\
\hline Australia & 17.000 & 18.000 & 8.600 .000 \\
\hline Argentina & 58.800 & 42.000 & $2.800 .000^{\mathrm{b}}$ \\
\hline China & 6.400 & 6.400 & 1.700 .000 \\
\hline United States & 7.100 & 7.500 & 1.000 .000 \\
\hline Zimbabwe & - & - & 630.000 \\
\hline Brazil & 1.600 & 1.600 & 230.000 \\
\hline Portugal & 300 & 300 & 95.000 \\
\hline $\begin{array}{c}\text { World total } \\
\text { (rounded) }\end{array}$ & 800 & 1.200 & 60.000 \\
\hline
\end{tabular}




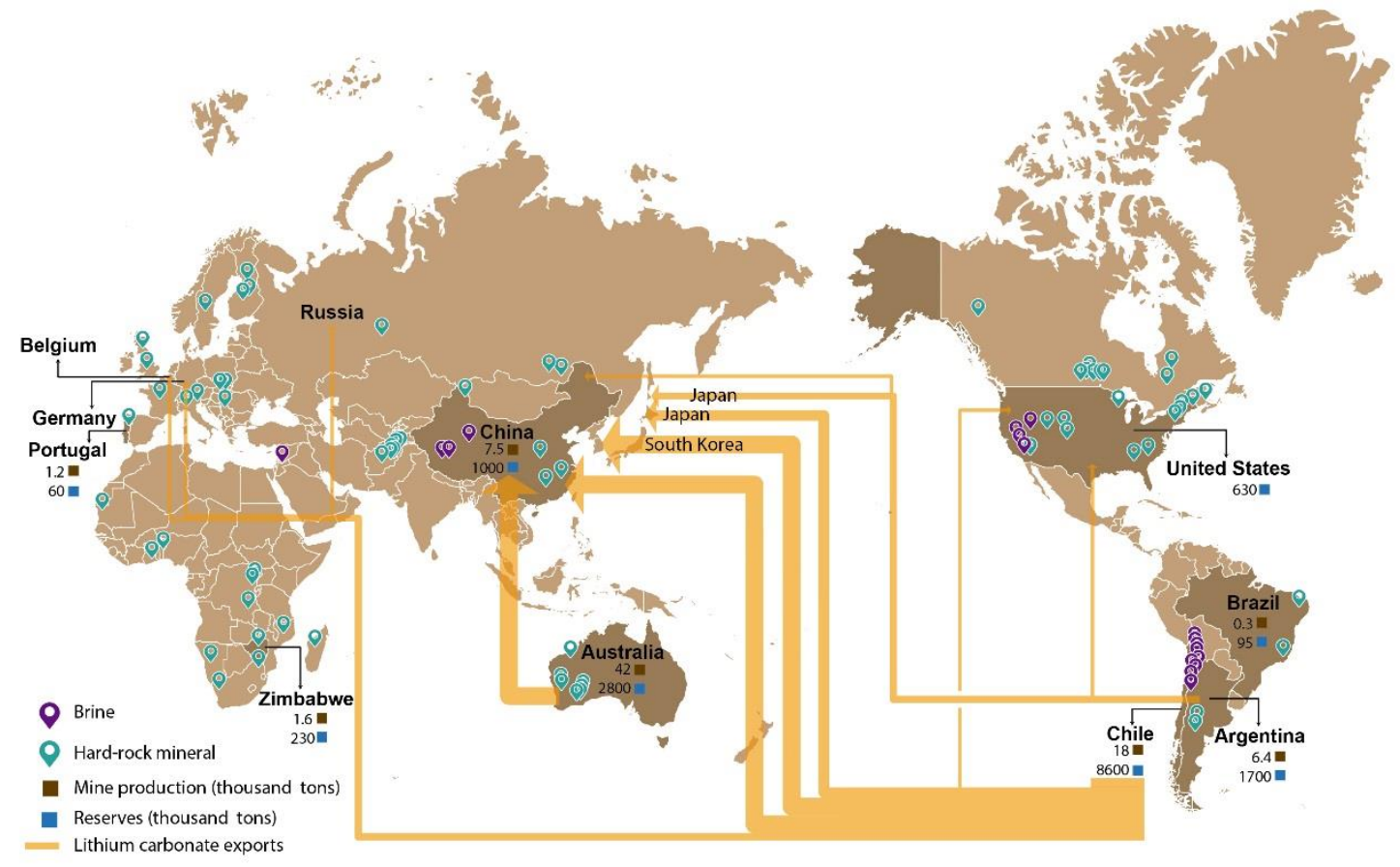

Figure 6 - World lithium reserves and exploits, and lithium trade.

\subsubsection{Lithium prices}

Lithium prices are affected by supply and demand, but three key drivers have a strong influence on them: (i) the Chinese market monopoly, (ii) the control of natural lithium reserves across the globe and, (iii) South American politic instability and social unrest. China is the leading manufacturer of consumer electronics and LIBs, but its market is heavily dependent on Australian spodumene ore imports as shown in Figure 6. Chile has the largest reserves, but Australia is the most productive country today. Second, three companies control $90 \%$ of the world lithium: SQM, American FMC Lithium and Albemarle Corporation. Last, the fast production volumes that are polluting groundwater heavily, and which will reach the regulated lithium extraction limits for 2030 near to 2023, [78] are stirring political and ecological turmoil in South America, particularly in Chile.

\subsubsection{The cost of LIB manufacturing}

The fabrication of LIBs involves different materials beyond the previously mentioned. From packaging to the active material, LIBs are composed of different metals and plastics, all of which have an impact on LIB price and the environment. Figure 7a shows the mass content contribution of the different materials involved in the fabrication of a battery pack for the automotive industry and Figure $7 \mathrm{~b}$ the cost of the larger contributors 
of these materials. It is observed that, despite the fact that some materials are used in very small amounts, their contribution to the final price of the LIB is much more significative, due to their high prices, such as cobalt and nickel, for example.

a)

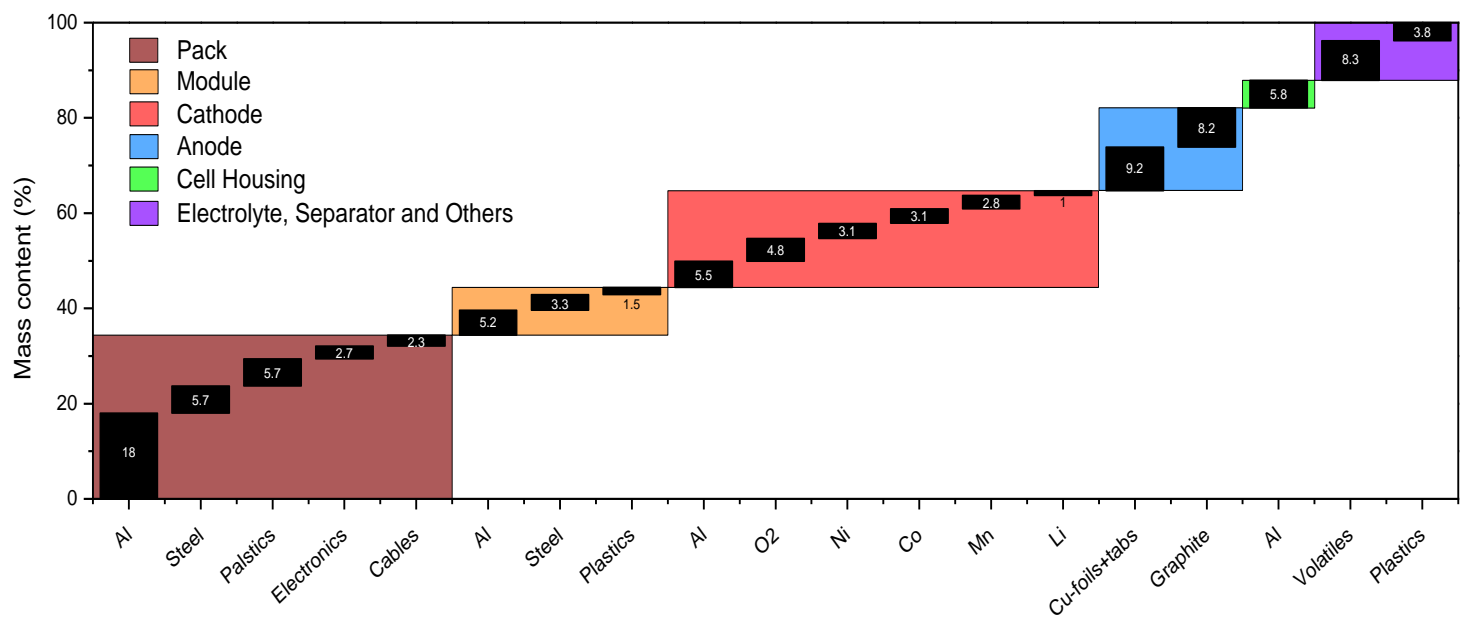

b)

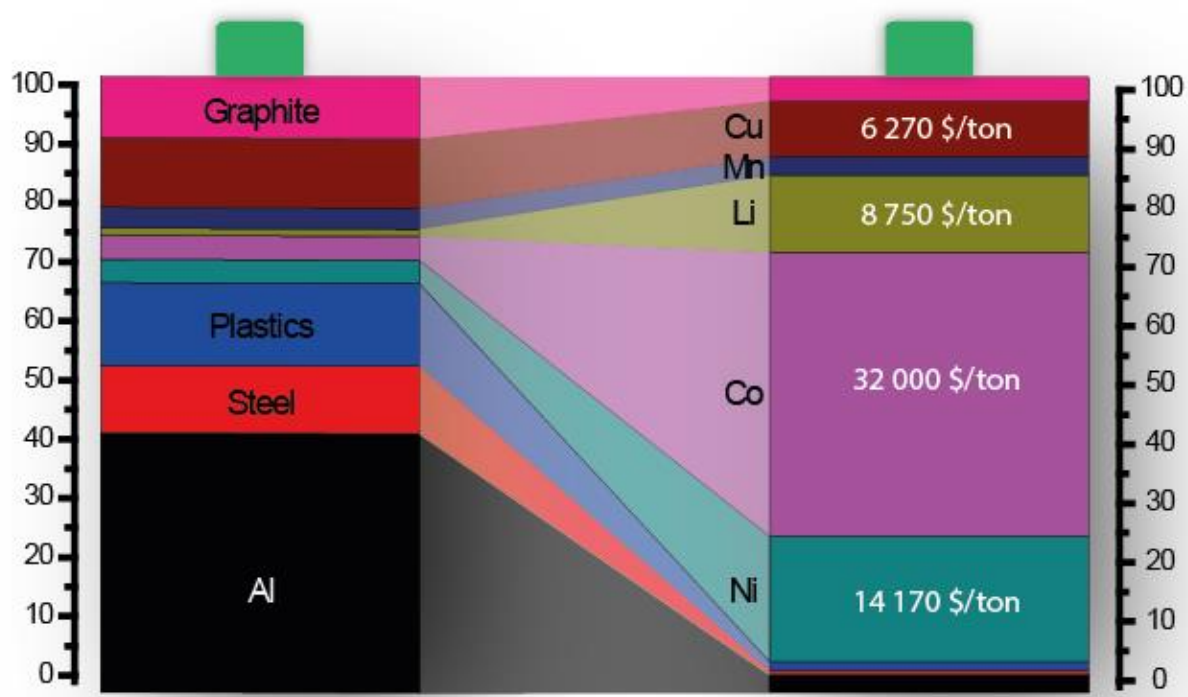

Weight $/ \%$

Cost $/ \%$

Figure 7 - a) Components of a LIB automotive pack and their mass content, based on [85] and b) manufacturing materials weight and cost percentage of a LIB.

Figure $8 \mathrm{a}$ also shows that materials cost represents $74.9 \%$ of the production of an automotive battery pack (graphite anode and NMC cathode). The primary strategies to reduce this figure are to find new materials with lower costs, or to improve the manufacturing process yield and productivity. Figure $8 \mathrm{~b}$ shows that the cathode accounts 
for ca. $49.5 \%$ of the total material costs. The metals, lithium, cobalt and manganese, and their scarce and expensive cost presented in Figure $7 \mathrm{~b}$, increase the manufacturing value of this component. Figure 8c shows how costs build up during LIB manufacturing. An undesirable effect of multi-step processes like this is that yield decreases as the likelihood of defects and production errors possibly increases. One way to reduce the number of process steps is to form strategic partnerships with material manufacturers, that can work together to find best battery conformation to later facilitate the recycling process [85].

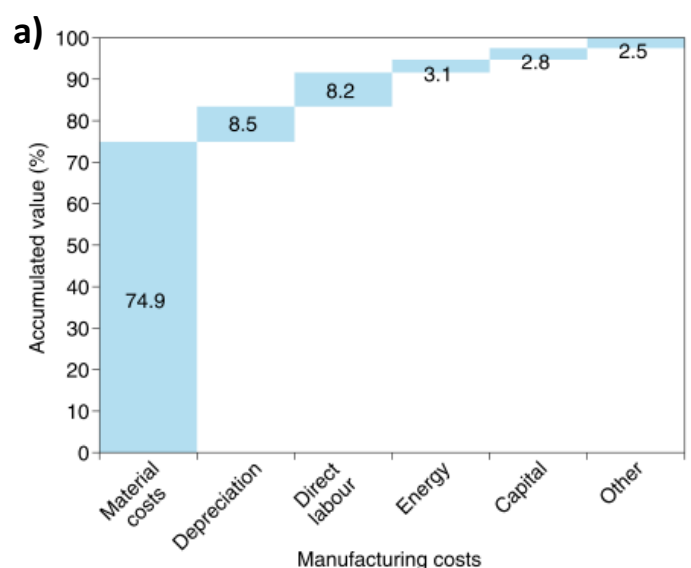

c)

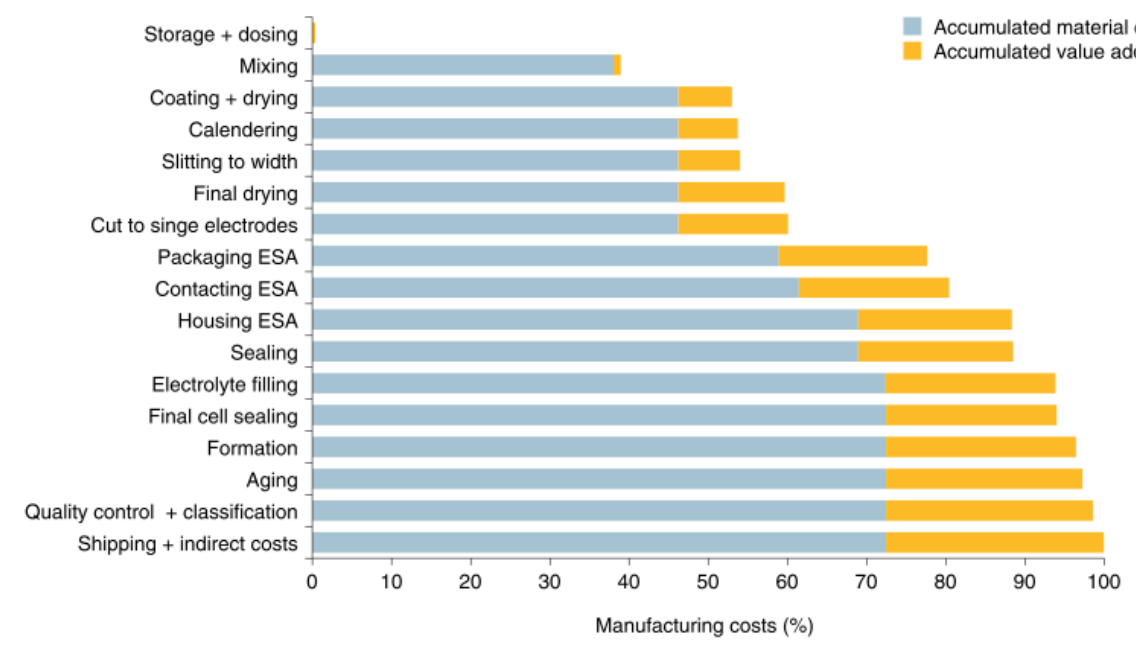

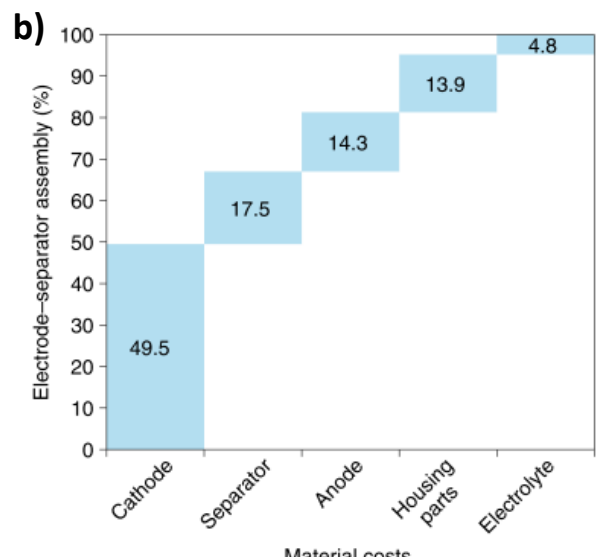

Material costs \%

\section{西}


Besides lithium, LIBs cost also depends on elements such as cobalt, graphite, nickel and manganese. Lithium battery cathodes, such as $\mathrm{LCO}$ and $\mathrm{LiNiO}_{2}$, contain 6-12\% of cobalt and 36-45 \% of nickel. Consequently, the increasing battery demand will also increase the price of these other metals in addition to lithium [87]. The price of cobalt has increased from 22 to $81 \mathrm{US}^{-1}$ between 2012 and 2018. Cobalt is expensive because it is comparatively rare and very sought after. Cobalt is usually a sub-product of copper and nickel mining, but it is uneconomical in that form, as most of those deposits contain only $0.003 \%$ of cobalt, whereas to achieve prices of 100 to $150 \mathrm{US} \$ \mathrm{~kg}^{-1}$, deposit concentrations above $0.1 \%$ are needed. As a result, roughly just $10^{7}$ tons of the $10^{15}$ tons available in Earth's crust are profitable to extract. In addition to cobalt, nickel is also rare, and only $10^{8}$ tons of the $10^{15}$ tons available are profitable to explore. Figure 9 shows the top country reserves and prices for lithium, nickel, cobalt and graphite [78]. Similarly, to lithium, the cost of nickel and cobalt also varies according to its availability in different locations with distinct socio-economical situations. On the other hand, the cost of graphite remains nearly constant due to its high availability worldwide.

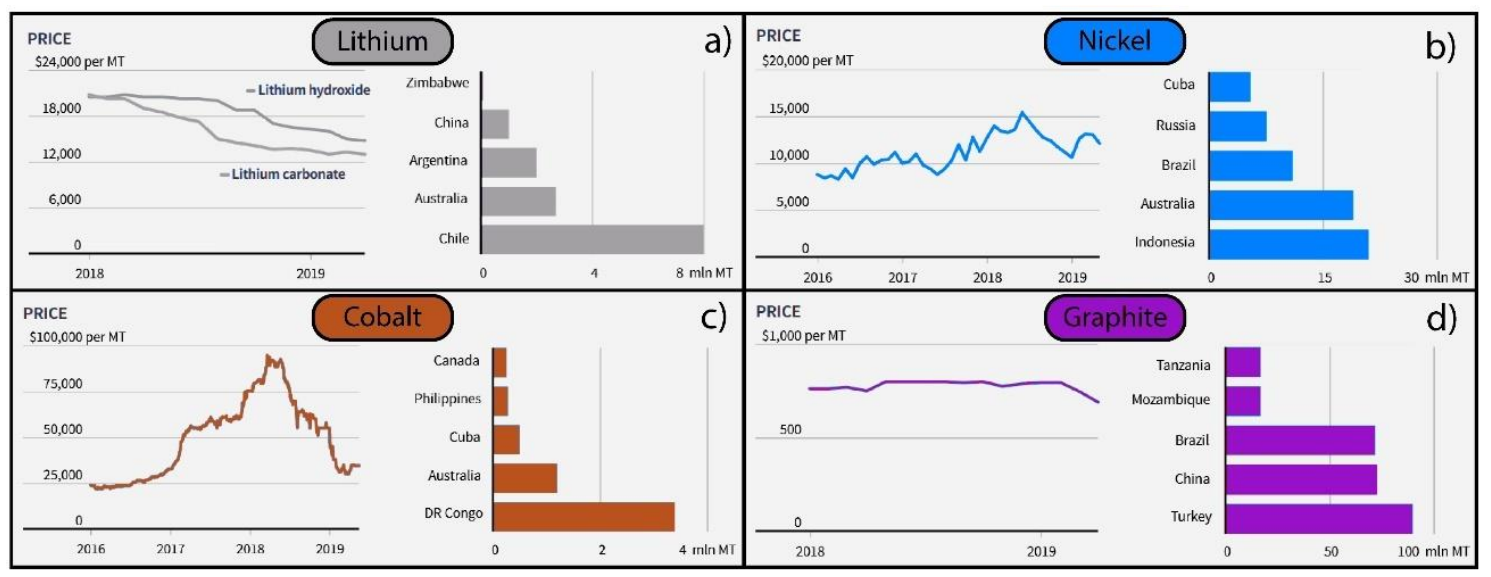

Figure 9 - Main country reserves and price trends for a) lithium, b) nickel, c) cobalt and d) graphite. Based on United States Geological Survey; Benchmark Mineral Intelligence; Refinitiv Datastream. Reuters graphics.

Next to lithium, cobalt is a key component in the fabrication of LIBs, in particular with respect to the future of the electric vehicle. The cobalt demand is expected to grow by $70 \%$ until 2020. An amount far higher than that of nickel (4\%) and manganese (2\%). As the LIB technology interconnects these elements, the impact of the increasing quantity of elements such as cobalt will also affect lithium demand. China, the first consumer of cobalt, commits $75 \%$ of it to battery production. The high demand of cobalt is one of the 
reasons for the scepticism surrounding LIBs for electrical mobility, as a demand of 190 kilotons per year is estimated by 2050 (around 70-kilo tons in 2019) [88]. That is why recycling assumes a critical importance in this field, in order to reduce the demand for pristine resources.

\section{Lithium-ion batteries: Environmental issues and recycling strategies}

The relevant economic and environmental problems stemming from how lithium batteries are used today are strongly intertwined. Some problems, as natural resource pressure and pollution resulting from exploration and processing of metals, are originated from the massive current and expected increasing future demand for lithium and heavy metals such as cobalt and nickel for energy storage. At the current pace of demand, the readily available lithium may run out soon, and its price will rise [89]. The situation is similar for cobalt and nickel, which are even scarcer than lithium. These and other environmental issues caused by the exploration, use and disposal of LIBs are approached in the following sections. Furthermore, recycling strategies will be discussed showing different ways to solve the mentioned economic and environmental issues from LIBs. The recycling processes that have already been studied are reported for each main LIB components, analysing their advantages as disadvantages.

\subsection{Environmental impact of LIBs}

Environmental issues are related to the extraction and processing of lithium sources but, more importantly, to the pollution resulting from the careless disposal of lithium batteries, which contain toxic materials, including heavy metals such as nickel and cobalt [90]. Focusing back on lithium, this metal is a scarce resource with very high demand. Exhausting lithium resources will worsen the above mentioned economic and environmental problems. Higher lithium prices will eventually turn the exploitation of low-concentration resources more attractive. This may still prove more accessible and more profitable than recycling, but it may well lead to additional/extensive environmental damage due to mining, extraction, and purification processes, that rely on energy consumption and production of industrial wastes. Despite the pressing need to use lithium and other metals required by LIBs more efficiently, the recycling of this type of materials and equipment is still about only $10 \%$ in global terms, implying that the remaining $90 \%$ ends up in landfills, making valuable materials unrecoverable $[11,12]$. 
This situation needs to be changed because natural lithium reserves alone cannot support the foreseeable future demand. This demand will be driven mainly by the transition to the electric mobility concept, that intends to replace the conventional internal combustion engine vehicles (ICEV) with the more environmentally friendly EVs. It has been proven that the emissions of an EV are significantly lower than the ICEV, particularly when the charge of the EV is made relying on renewable energy sources, according to an European Commission study (Figure 10) [91]. These results include the environmental cost of the production and disposal of batteries in the EVs and are caused by the significantly lower number of parts of an EV when compared with an ICEV.

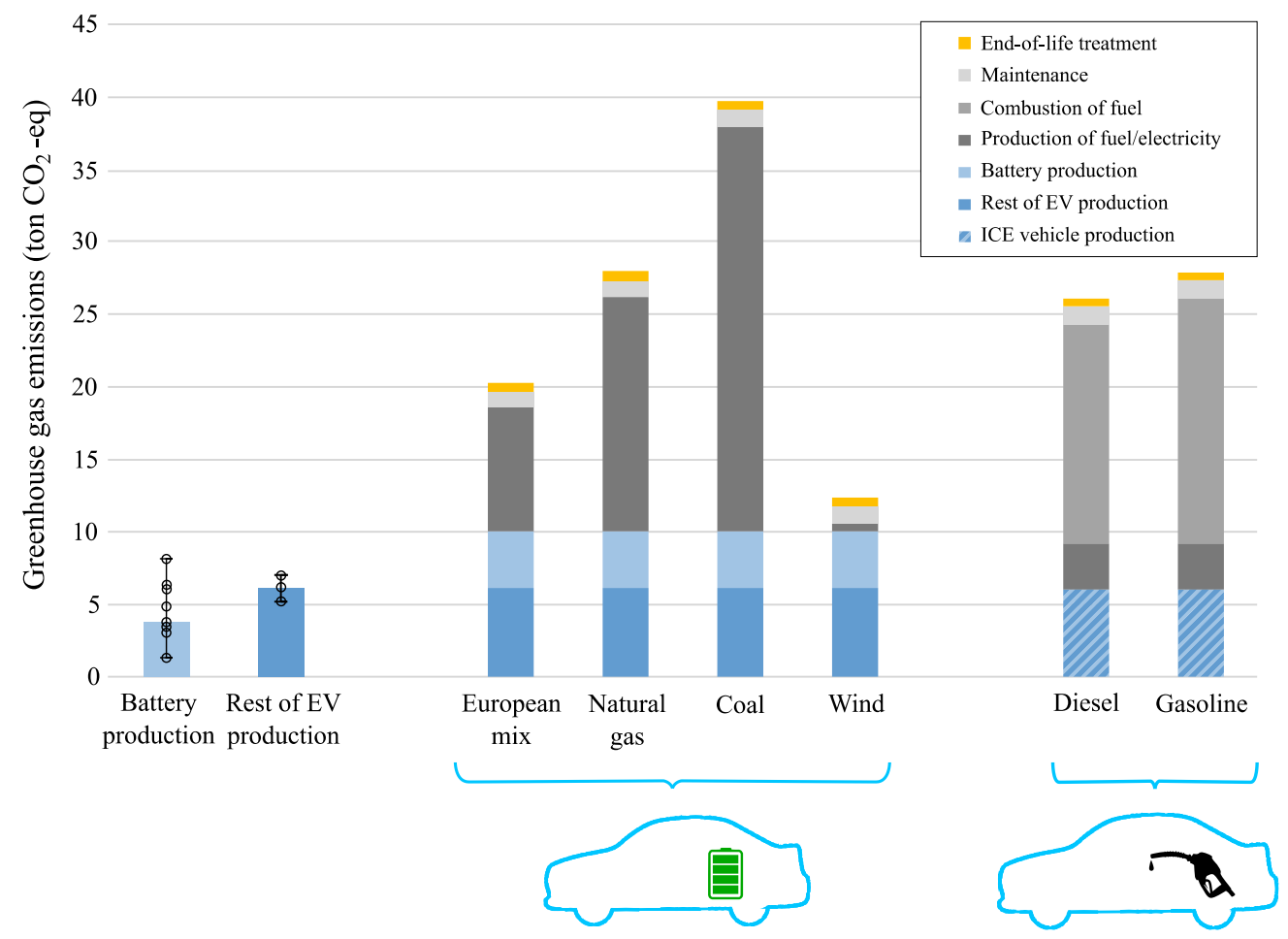

Figure 10 - Lifecycle GHG emissions of mid-sized $24 \mathrm{kWh}$ battery EV and ICE vehicles [91]. The vehicle's operational lifetime is assumed to be $150000 \mathrm{~km}$.

Although EV production stage is more carbon-intensive than ICE vehicles once battery production is considered, EVs can compensate this in the use stage, and become ecofriendlier with the use of an electricity mix that is based more on the renewable sources. With the expected growth of the EV market, due to the reasons stated above, it is also expected a huge demand on the LIB demand for the automotive industry, which will urge even more the necessity of recycling the spent batteries, to respond to the needs of the production chains, and simultaneously reduce the disposal of spent batteries.

Despite their advantages, LIBs present different environmental impacts, in particular during the production process and at the end of their life cycle. Recycling, in combination 
with renewable energy sources, can reduce the environmental footprint of the LIB industry. Recycling mainly protects the environment in two ways through the recovery of scarce and valuable materials. First, metal recovery reduces the dependence on mining and refining. Second, recycling minimises the amount of waste which, in many cases, also happen to be toxic (due to the use of toxic elements and some acids) or nonbiodegradable [92].

LIBs are better than primary batteries in terms of natural resource conservation because they can be used multiple times, avoiding the extraction of more resources to fabricate new devices. However, to fabricate truly environmentally friendly LIBs, the energy stored in batteries should be also mainly from renewable sources.

Clean and efficient energy sources are essential to decarbonising the economy and hence reducing greenhouse gas emissions. Such systems would allow to charge batteries during high production hours that would be discharged later, during periods of higher demand. This section covers some of the most critical environmental effects associated with LIB production, operation, dismantling and disposal.

Life Cycle Assessment (LCA) of LIBs is a powerful tool in the product development phase to identify potential hazards, environmental impacts and relevant stages in the product life cycle [93], so that the right measures can be adopted at each stage $[4,9,15]$. It allows the modulation of different theoretical situations, introducing different relevant variables and comparing the results that can potentially be applied in practice. LCA also allows comparing the impacts of different production chains and can make predictions of the future industry impacts in different scenarios [94]. LCA shows the contribution of different steps and components in the environmental impact of each device, which allows the possibility to replace them with more sustainable ones, reducing the global impact of the battery [95]. Last, it can help assess human health impacts in the different life stages of a battery [96]. However, it is difficult to have access to all needed data, and some critical assumptions have to be made, which can sometimes lead to inaccurate predictions [97].

For instance, the life-cycle of lithium-air batteries has been analysed from raw materials production to recycling process in order to evaluate the main environmental impacts when compared to those of other types of battery and to study their potential for a sustainable wide range application [98]. The study shows that the production phase generates the most impacts. However, the increase in cell efficiency results in the production of fewer cells [98]. The new main impact in this new scenario is caused by energy losses in the 
form of heat during the battery charge/discharge process. Compared to the best battery technologies today, the environmental impact of lithium-air batteries is 4 to 9 times lower. Recycling can prevent 10 to $30 \%$ of the production-related environmental impact. However, no large-scale recycling methods are currently in use, once lithium-air batteries are not widely used nowadays [98].

Regarding the benefits of recycling versus mining and refining lithium and rare metals, the increased demand will lead to higher lithium prices, making the exploitation of less accessible reserves profitable. However, exploiting those lower-quality reserves will have negative impacts on the explored areas. It is therefore essential to find alternatives to diversify the energy storage systems and to prevent the intensive exploitation of natural resources alone [99]. Estimations of future battery recycling claim a reduction of the dependence on natural resources by up to $50 \%$. Because not all materials are recyclable, natural resources will also continue to be necessary [15].

When applied to a circular economy scenario, the waste management of spent LIBs shows excellent potential to reduce the use of energy in the production of new devices. The application of the spent LIBs in stationary energy storage systems can increase even more this effect [100]. However, the recycling and reuse of materials from spent LIBs is not always cost-effective. Depending on the type of battery and the materials involved, the cost of the recovery can be higher than the extraction cost of new materials [101].

Like every other industrial process, the production of LIBs presents hazards and environmental risks associated with the synthesis of materials, fabrication processes and waste management. Cathode scraps from the industrial production of LIBs can be treated to recover pure metals such as $\mathrm{Co}, \mathrm{Ni}$ and $\mathrm{Li}$ using a sulphate leach mixture in a selective extraction process. This strategy significantly reduces the environmental impact associated with the industrial production of batteries and optimises the use of mineral resources [102]. An interesting and eco-friendly approach consists in the use of biodegradable and low-cost materials, such as chitin and rice husks, as adsorbents for recovery of cobalt from leaching steps of recycling of used LIBs. It was concluded that $\mathrm{pH} 6$ is the best for adsorption of the metals, which presents a pseudo-second order model curve. Cobalt recovery rates up to $95 \%$ were achieved using chitin $\left(50 \mathrm{mg}^{\circ} \mathrm{g}^{-1}\right)$, which makes it an ecological and low-cost adsorbent to recover valuable materials from used LIBs [103].

LIBs also present issues related to ecotoxicity and human health. In faulty or incorrectly used LIBS, short-circuits, overcharging or overheating can lead to fires and explosions. 
Safety tests have been developed to avoid these incidents throughout battery life. However, the large variety of devices with different compositions and characteristics results in different performance during these tests. As a result, despite these safety checks, incidents still happen occasionally [104].

Moreover, a significant number of battery models show higher levels of cobalt, copper and nickel than recommended [105]. Some even contain lead and thallium, which significantly increase the ecotoxicity of LIBs (Figure 11) [105]. Lithium manganese oxide and lithium cobalt oxide are other materials used in LIBs with proved long-term chronical effects on some crustacean populations [106].

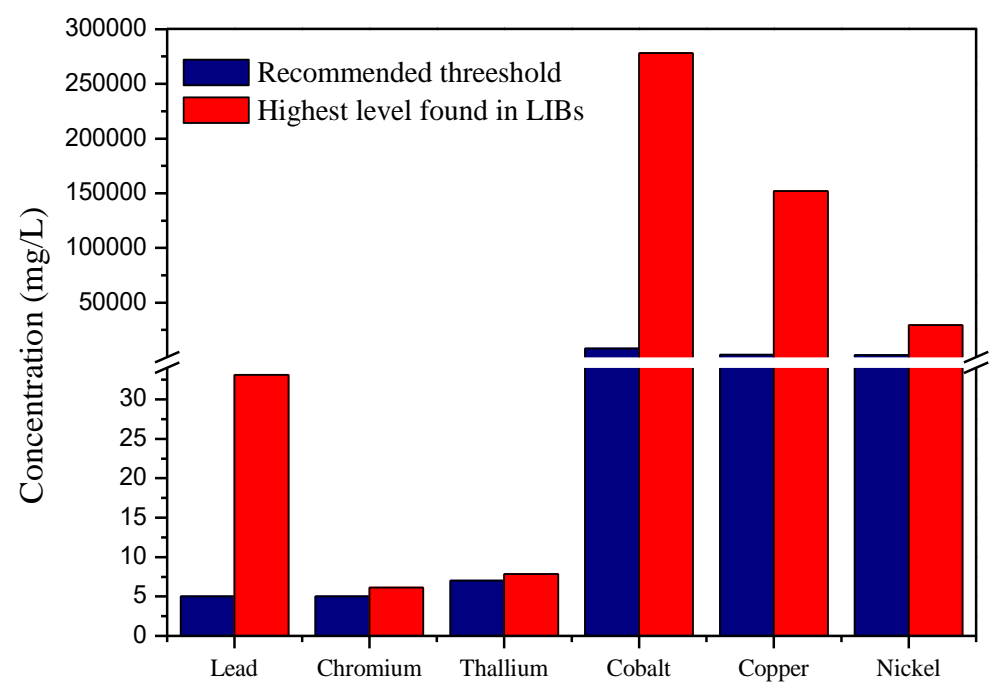

Figure 11 - Comparison between the component levels measured in LIBs and the recommended threshold. Based on [105].

Replacing the most hazardous components in a battery with safer materials is a valid approach to reduce the negative impacts of LIBs. An interesting work focusing on organic LIBs based on dilithium benzenediacrylate electrodes, presented an environmentally friendly recycling process Water is used for solubilisation of the organic electrode material, which is much less harmful than the conventionally used DMF or NMP solvents, but there are some concerns on the effect and stability of water in the battery [107]. The recycling potential of LIBs has been compared to present recycling systems of leadacid and nickel-metal-hydride batteries. Despite their environmental and operational advantages compared to secondary batteries, the latter are more easily recovered because they have similar composition and construction, and this allows the recovery of high- 
quality materials using nearly the same processes. On the other hand, there are many different types of LIBs, and the range of materials involved is too wide to enable the development of "universal" recycling systems. Different processes have been proposed addressing the recovery of specific materials from different battery types [108].

An enhanced method for improved separation of copper, cobalt and lithium was developed [109]. The proposed method uses self-driven microbial fuel cell (MFCs) and microbial electrolysis cells (MECs), which are considered as promising technologies, due to less energy consumption associated. Consequently, this leads to an environmentally friendly global process of batteries recycling [109]. The use of DL-malic acid $\left(\mathrm{C}_{4} \mathrm{H}_{5} \mathrm{O}_{6}\right)$, as leaching agent, is reported as an innovative way to fulfil an environmentally friendly leaching method, to recover cobalt (90 wt.\%) and lithium (nearly $100 \mathrm{wt} . \%$ ) metals from cathode active materials. The combination of hydrogen peroxide in a DL-malic acid solution can effectively step up the leaching efficiency [110]. Also, the utilisation of DLmalic acid can contribute to a final regenerated cathode active material, which presents high specific discharge capacity of $147.2 \mathrm{mAh} \cdot \mathrm{g}^{-1}$, and favourable electrochemical cycling performance [111]. The literature reports on a new strategy to recycle materials from spent LIBs, based on the use of organic linkers as leaching agents, which in turn can precipitate the valuable metals as polymers from a NiMnCo solution [112].

Finally, some battery components can be put to other uses before recycling them at the end of their life. Spent cathodes from LIBs can be used as catalysts in the degradation of organic dyes, solving the problem of the spent LIBs disposal and the textile industry effluents treatment simultaneously. $\mathrm{LiCoO}_{2}$ was shown to degrade methylene blue 200 times faster than pure $\mathrm{H}_{2} \mathrm{O}_{2}$, because of the reduction of this process' activation energy [113]. Anode materials can also be reused successfully. Zhao et al. prepared an adsorbent for treatment of heavy metals in waters using $\mathrm{MnO}_{2}$ modified graphite sorbents, with high removal rate for $\mathrm{Pb}$ (II) $\mathrm{Cd}(\mathrm{II})$ and $\mathrm{Ag}(\mathrm{I})$ [114]. 


\subsection{Recycling strategies: direct recycling, pyro- and hydrometallurgical processes}

The question about recycling is not whether to recycle or not, but how to do it most effectively. Market forces and regulation will determine whether and when used batteries undergo remanufacturing, refurbishing or recycling, and what are the most effective processes to achieve those objectives.

The adoption of recycling techniques and processes, framed in a closed loop (circular economy), is considered as the fundamental way for a more sustainable use of materials and resources when compared with the way they are used nowadays, while also avoiding the real risks of environmental pollution and public health issues related to toxicity. This circular economy concept will lead to more cost-effective devices, creating a more competitive and greener economy, and reducing the need to extract and process natural resources continuously. Additionally, the reduction in the production of new materials and the use of less energy demanding processes will further promote environmental sustainability by lowering the current dependence on the carbon fossil fuels [115].

Different tools and models exist to quantify both the economic and environmental implications of the LIB supply chain. Thus, material flow analysis quantifies the flow and stocks of materials [116]. On the other hand, the life cycle cost indicator can determine the expenses throughout the full cycle life of a battery [116]. Using more specific perspectives, cost-benefit analysis is a decision tool to assess the best approach in terms of economic advantages and, last, eco-efficiency can be defined as the ratio between the economic benefit and the environmental gain or the material recycling rate, performing the calculation of the overall performance of a determined recycling process or facility [116].

The material and energy flow analysis (MEFA) is a method to interpret the complete or partial processes to determine the possible sources and consumers of the materials, substances, pollutants and their corresponding energy flows of the processes. A newsworthy MEFA study was conducted on the production step of the LIBS, considering the materials included in the batteries, such as electrodes, electrolytes, metal-salts, plastics and other metals, like the casing and current collectors [117]. The analysis results prove that recycling based in thermal processes like smelting is recommended, using $80 \%$ less energy than the process of production of new original materials. According to the authors, considering the share of energy consumption of new materials and component productions in the overall energy necessary for a battery pack production, the recycling 
of a cathode electrode material can achieve a reduction of $21.6 \%$ to $15.9 \%$, resulting in a whole energy demand reduction of the recycling process estimated in 5.7\% [117]. As alternative to the recycling of the battery components, the reuse of spent batteries in applications that require less energy consumption is also a valid option. Data show that most discarded batteries can still work at acceptable performance levels for many chargedischarge cycles [118]. However, if material recycling is a more profitable option, then remanufacturers may prefer to recover and recycle the materials instead of reuse the complete devices [118]. Possible reuse of laptop LIBS through the evaluation of the number of charge and discharge cycles can be used to check the most cost-effective recycling plan for these batteries. The study demonstrates that reusability information can help defining the most effective pricing policies in order to address whether the most successful path is to reuse the battery or to recycle its components ${ }^{[77]}$.

A study has been presented considering the scenario of the reuse of LIBS from mobile applications, such as smartphones, in remote areas of developing countries. The idea is the collecting of the batteries from end-of-life smartphones and keeping them for a second life as to store solar energy. Many areas in developing countries are remote and isolate, and require the use of off-grid electricity systems. This limited electric supply makes even lighting difficult [119]. Second-life batteries can be connected to solar panels for charging, and then be used to power LED-based systems. This represents a safe, sustainable, reliable and low-cost light source, that can replace candles and kerosene lamps. For example, a 2-year-old standard LIB (2000 cycles of charge/discharge) that was used with a rate of one cycle per day, will have 1250 cycles left at the end of the average smartphone life. A $12 \mathrm{~V} 3.1$ Ah battery will have the energy to powering a $5 \mathrm{~W}$ LED lamp for 4 hours at the cost of $\$ 35$ per unit and will last for three years. This compares well with the typical annual cost of candles and kerosene lamps, established as \$54 [120].

Higher lithium prices will encourage the thorough use of lithium batteries in "secondlife" applications and their recycling at their end of life. As an example, Busch et al. report on a scenario where LIBS from electric vehicles are reused in grid-attached energy storage [116]. Therefore, the reuse of the batteries can offer an outstanding resource economy and significantly reduce the demand for new cobalt and lithium. In terms of demand indicators, the reuse of batteries from vehicles to grid-attached storage can contribute to a notable reduction of primary lithium demand by up to $30,000 \mathrm{~kg}$ per year 
after 2030, and a worldwide reduction in the cobalt demand, which can be decreased by around $30 \%$ in 2033 [116].

Attending to the previously discussed topics, government incentives to battery re-use and recycling through legislation, education and tax policies are highly recommendable to accelerate the transition to a more sustainable economy. For example, considering subsidies and tax breaks for industrial companies is a way to generate profit for the recycling industry, and to make this process more economically appealing [11]. However, tax relief alone does not work, and other measures are simultaneously needed too. A recent study conducted in China showed that even if people know that batteries can be recycled and want to recycle, a majority does not know where to return their spent batteries [12]. Thus, country-wide recycling systems also need a collection infrastructure that is widely known to the population. Some of the proposed solutions include that the government may partially support this infrastructure, i.e., creating state-owned collection stations. The implementation of the recycling concept in public education at an early stage is another recommendation, ensuring that environmental concerns are respected and considered early on. The academic community can also contribute by developing more and better recycling strategies and techniques, fully taking into account that these approaches need to be transferred, implemented and scaled up at the industrial level, thus allowing the effective massive recycling of the materials of the LIBS [12].

From a business perspective, recycling is a source of new opportunities, particularly in countries with little or no natural lithium resources. In Europe, EC Directive 2006/66/EC states a clear objective to minimise the adverse effects and impact of batteries on the environment. The shift towards the electric vehicle can put the European combustion automotive industry at risk, if it is not prepared for the needed changes. Car manufacturers are now acting on the realisation of the strategic importance of batteries to their future business model. While many are investing heavily on battery manufacture, few are known to be investing in battery re-use and recycling.

Meanwhile, the recycling assessment is based on a metric named recycling efficiency, defined as the ratio between the recycling output fraction and weight of recycling input fraction, and a target of $50 \%$ is set. In the specific case of the Umicore industrial battery recycling process flow, which includes the recycling of used batteries from hybrid and electric vehicles, the effective recycling efficiency (60\% for steel casing batteries) is better than the target set by the EC directive [121]. Different companies have their own recycling chain processes, that combine various methods to recover the different materials 
at distinct efficiencies. However, There is still a gap between the environmental concerns and the technological developments, that needs to be close, by improving the recycling efficiencies and the sustainability of LIBs [122].

The German government, in turn, has established a strategic plan to promote sustainable growth of electric mobility [123] and gain industrial leadership in this emerging area. The growing use of electric vehicles has led to the necessity to organise a recycling plan for the creation of economic value from spent batteries. For this, investment plans for the implementation of recycling industries with economic profit available for potential investors, have been studied. Likewise, these recycling industries will severely reduce the waste material volume from spent LIBS, and consequently increase valorisation. The study results show that, due to the expected future growth of the utilisation of electric vehicles, the estimated annual amount of waste will reach 340,000 metric tones by 2040 in Germany [123]. There are ongoing plans to select strategic locations for collection and treatment industries, involving several partners in the supply chain: electric vehicle dealers, vehicle treatment operators, battery and material manufacturers and the recycling agents. This industrial strategy requires the creation of a joint consortium network where all the partners share costs and the business risks associated with the collection and recycling processes in order to lower the risks in the long term [123]. The aim is to make the battery recycling market more attractive for incoming investors. This means that batteries from electric vehicles need to be correctly electrical and thermal managed by an end-of-life strategy, which requires to be framed within the vehicle life cycle and supply chain.

The chemical analysis of used batteries provides insights and valuable information for the proposal and execution of recovery methods and recycling plans. $1 \mathrm{~kg}$ of sieved $(<1$ and 1-3 mm) and magnetically separated lithium battery $\left(\mathrm{LiCoO}_{2}\right)$, waste materials with less than $3 \mathrm{~mm}$ particle size contains about $250 \mathrm{~g}$ of cobalt, $120 \mathrm{~g}$ of copper, $110 \mathrm{~g}$ of nickel and $31 \mathrm{~g}$ of lithium that can be recovered. Also, a low metal release to aqueous solutions was verified [124].

As stated before, sometimes a spent battery is reused in a second use approach, in applications that do not require its full original capacity (Figure 12). Afterwards, once LIBS reach their end of life, different recycling strategies may be followed. The main approaches to recycling are "direct recycling" methods and "pyro- and hydrometallurgical" methods. 
Direct recycling approaches aim to recover and refurbish the cathode material (active material mainly) to produce new batteries with it. Herein, methods are presented that apply a re-functionalisation of the active material and others that directly precipitate the desired active material, from spent LIBs cathode powders. Pyro- and hydrometallurgical methods, on the other hand, focus on recycling the metals and components of the battery. Their goal is to recover valuable components/elements from the end-of-life LIBs for later use as raw materials to be used directly in the production of new batteries.

Each of these approaches has its advantages and disadvantages. Pyro- and hydrometallurgical methods are unspecific and yield high recycling rates on the elements. However, several different steps may be needed to recover all the metals and materials of interest, which may involve toxic solvents and concentrated acids for the recovery, possibly leading to health problems and safety hazards, associated to the dangerous materials handled during the manufacturing process. In contrast, the main advantage of direct recycling methods is their high specificity, as they seem to address only one active material at a time. Akin to direct recycling methods, some direct recycling methods also use toxic solvents and acids in the process. However, these are a minority. This is because most methods focusing on the re-functionalisation of the active material are based on high-temperature processes. Although thermal processes may be considered more green, due to the fact that they are acid and solvent free, they can be disadvantageous, as their high energy consumption may deem them unattractive.

A negative point of both approaches is that very few authors mention what is done to recover the other parts of the battery, for example, anode material, current collectors, electrolyte, separator, and plastics.

As a final note, an essential difference between these two approaches is that while pyroand hydrometallurgical methods are measured in terms of recovery rates, direct recycling methods are measured in terms of battery performance. The latter does not provide information on recovery rate, which makes it more challenging to evaluate the efficiency of the process. Instead, the electrochemical performance of the new battery is compared to that of the "original" one. Although almost always the performance is excellent, in the new battery, there are always performance losses, and very few [125] information is found on the number of times that a given battery/active material can be recycled before the electrochemical performance becomes unacceptable. 


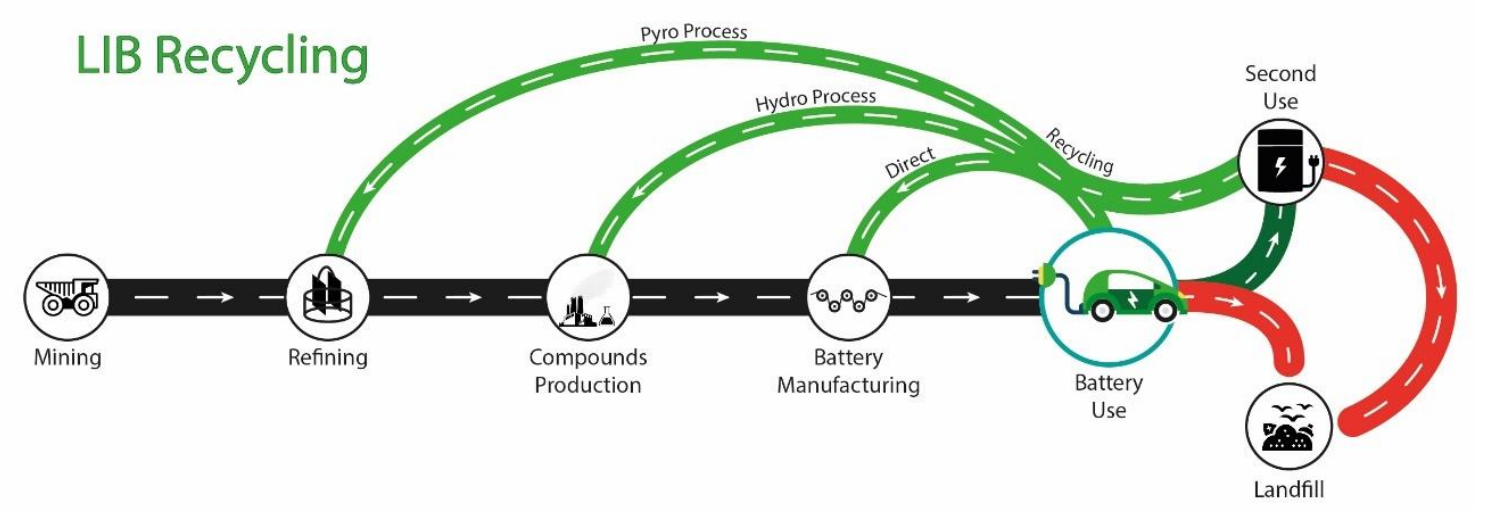

Figure 12 - Lithium-ion battery recycling routes.

\subsection{Recycling of lithium-ion batteries}

After battery use, different approaches can be followed (Figure 12). The first relevant decision is whether to dispose the spent battery in landfills, which should be avoided, or to reuse/recycle it. As stated before, the battery can be reused in other applications, and for that, battery health must be considered. When the battery materials are too degraded to use, whether they come from first or second use, different recycling paths can be followed. Each recycling process will lead to the different stages of the battery production chain. Direct recycling methods lead to the battery manufacturing, hydrometallurgical processes lead to the compounds' production and with pyrometallurgical processes it is possible to obtain the raw materials [126].

Different types of batteries, including nickel-metal hydride, rechargeable LIBs and primary LIBs may be recycled in a unique mechanical route process, avoiding the necessity to separate the spent devices into parts. The powder obtained from the mechanical pretreatment, which includes a two blade rotors crusher and a hammer crusher with a $5 \mathrm{~mm}$ sieve, can be further subject to chemical leaching, allowing the extraction of cobalt, nickel and manganese [127]. A process to recover most of the battery compounds, using simple, cost-effective, and environmentally friendly methods was developed. This process is based on selective dissolution in dilute acid, which precipitates the metal part of the battery. After that, chemical and thermal treatments allow the recovery of almost all battery components, including insoluble plastics, transition metals and alkaline ions [128]. In another approach, the use of water and the contents of waste Li-ion batteries for the electrodes in a Li-liquid battery system has been demonstrated in which electricity was produced [129]. 
Most recycling methods, on the other hand, require the separation of the battery into parts, as they specialise in the recovery of materials from specific components.

Regarding the selection of the best recycling processes and methods, the combination of several criteria supports decision models for the selection of the optimal recycling solution. Among these criteria, environmental impact, energy consumption, health and safety factors, recovery of materials, process time, labour cost, initial facility investment and flexibility rate are the most common. Depending on how they are combined, a fuzzy multi-criteria decision logic model (analytical hierarchical process) can provide several combinations and results. Despite the criteria specified, some authors support that the best operational recycling combination results from the aggregation of hydrometallurgy and pyrometallurgy processes [130]

Pyrometallurgical processes operate at high temperatures and are usually associated with high atmospheric emissions. Hydrometallurgical processes, on the other hand, consist of leaching steps in acid or alkaline medium and purification processes to dissolve the metallic fraction [131]. The main final products obtained from pyrometallurgy and hydrometallurgy are alloys/metal compounds, and solutions containing metal ions, respectively [131].

\subsection{Recycling processes for batteries}

The first approach to consider involves processing the whole battery rather than the separate components. Toxco and Sony processes are two commercial LIB recycling processes already in use. In the Toxco process, the material is cooled in liquid nitrogen and then shredded. After that, the lithium is set in contact with water, where it reacts to produce hydrogen, and allows the recovery of metallic cobalt and lithium hydroxide. In contrast, the Sony process involves heating the battery materials. Then, the lithium, plastics and hydrogenated compounds are caught by mean of a proprietary gas treatment system, while cobalt is subject to a hydrometallurgical process [131]. The use of microwaves to promote the carbothermal reduction of the cathode materials, using the graphite from the anode under ambient condition proved to achieve better recycling rates than recycling the electrodes separately [132].

The hydrometallurgical recycling process consists of several intermediate steps to achieve the recovery of valuable metals and materials. Broadly, the batteries are classified by type, dismantled and completely discharged trough a deep discharge step to avoid safety risks 
of possible reactions with air. Batteries may be dismantled by crushing, sieving, milling, froth flotation, pneumatic, magnetic and densimetric split process [2].

The final particle size of wet and dry crushed materials of wasted LIBS was studied to assess the differences. Wet crushing uses a blade crusher equipment with water medium, in which the particles fed to the crusher at high speed, are fractured when they encounter to the stationary elements of the crusher. In the dry crushing method, batteries are chopped into pieces with a shear crusher, followed by crushing by impact. XRD, SEM and EDX analysis results showed that the dry technique led to a more selective crushing of the components, as well as to the obtention of purer electrode materials [133].

Hyuntae Bae et al. have developed an innovative waste-to-lithium (WTL) recycling system. The system, represented in Figure 13, consists of a delithiation electrochemical reaction in which the lithium metal is harvested from lithium-containing waste materials through a charge step. Moreover, by a discharging process, the harvested lithium metal is recycled into air-stable $\mathrm{LiOH}$ by reaction with water, and then, by reaction between the obtained $\mathrm{LiOH}$ and $\mathrm{CO}_{2}, \mathrm{Li}_{2} \mathrm{CO}_{3}$, is produced. The authors claim that with this method, the recycling of spent LIBS can be boosted up, by a cost-effective and manageable scaling approach because the system is designed to work at room temperature, avoiding the use of heat and elevated temperatures, or even hazardous acid chemicals [134]. A method to reactivation of the active materials was developed, based on ultrasonic hydrothermal renovation. In this process, the spent $\mathrm{LiCoO}_{2}$ is removed from the collector, separated from the organic compounds and reactivated with $\mathrm{H}_{2} \mathrm{O}_{2}$ and $\operatorname{argon}$ at $90{ }^{\circ} \mathrm{C}$. The recovered active materials can be applied in new batteries with discharge capacities of around 130 mAh.g ${ }^{-1}$ [135]. $\mathrm{LiCoO}_{2}$ can also be recovered by calcination at high temperatures and addition of $\mathrm{Li}_{2} \mathrm{CO}_{3}$, allowing for regeneration of the cathode materials with similar properties to those of the commercial materials [136]. This $\mathrm{Li}_{2} \mathrm{CO}_{3}$ can be obtained by the recycling of $\mathrm{LiCoO}_{2}$ by the addition of $\mathrm{NaCl}$ and $\mathrm{SiO}_{2}$ as mechanochemical reaction agents and $\mathrm{Na}_{2} \mathrm{CO}_{3}$ as precipitation reagent, via a sustainable recycling process [137]. The application of DC electric fields in spent LIBs is also a versatile and green strategy to extract lithium ions from the cathode structure, and dissolve them in aqueous solution [138]. Other cathode materials, as $\mathrm{Li}\left(\mathrm{Ni}_{0.6} \mathrm{Co}_{0.2} \mathrm{Mn}_{0.2}\right) \mathrm{O}_{2}$ can be regenerated by roasting at $350^{\circ} \mathrm{C}$, followed by the addition of $\left(\mathrm{NH}_{4}\right)_{2} \mathrm{SO}_{4}$, in an acid free process, without any reduction agent [139]. $\mathrm{LiMnO}_{2}$ was reportedly regenerated using a pyrometallurgical process, by application of high temperatures, and addition of manganese acetate. The recovered cathode presented acceptable battery performance [140]. 


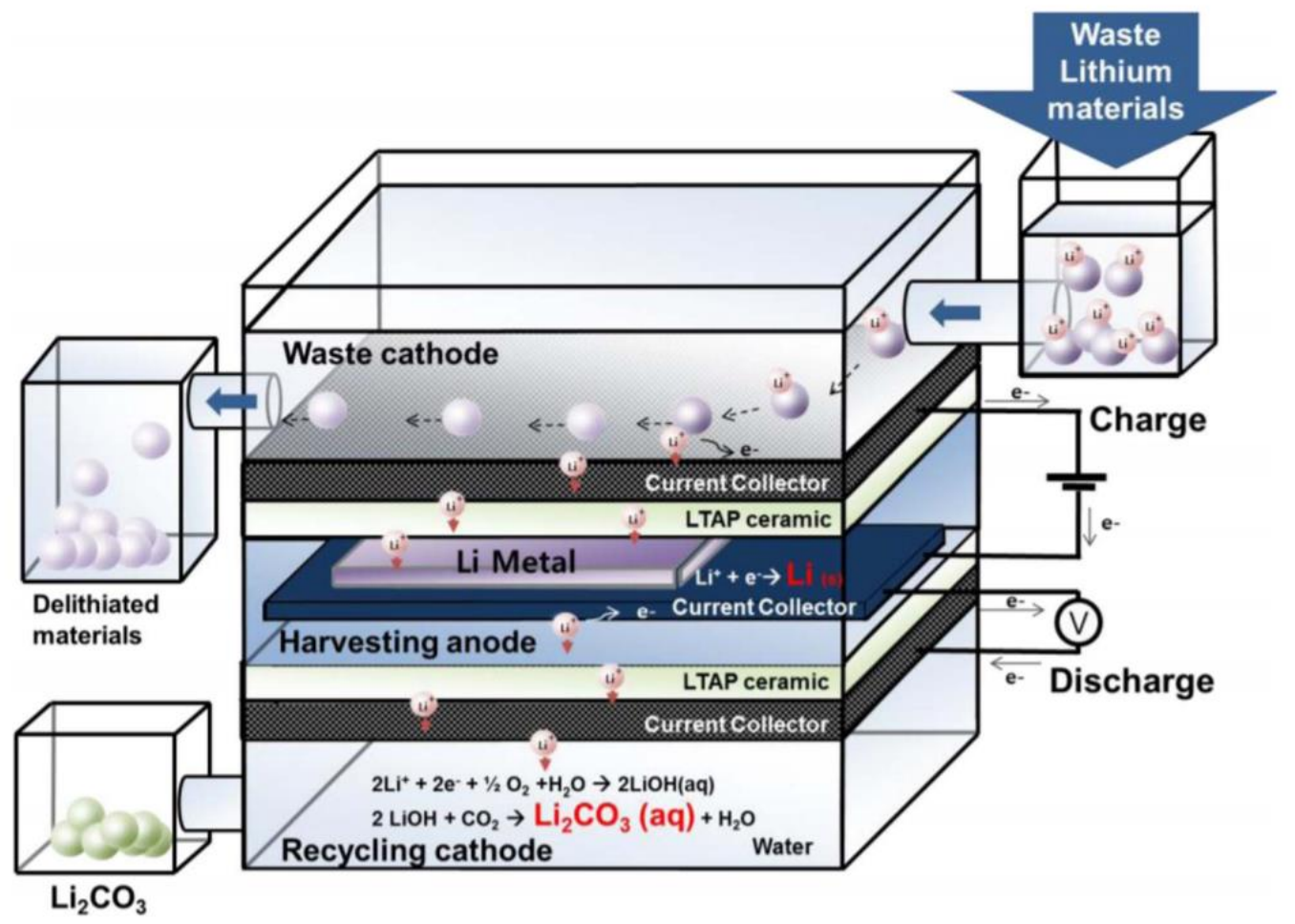

Figure 13 - Schematic representation of the waste-to-lithium system [134].

Chemical precipitation can be considered as an alternative way to process the recycling of spent batteries, allowing the recovery of pure metal salts from $\mathrm{LiFePO}_{4}$ active material. This strategy was designed with a base in the called solid-liquid equilibrium phase behaviour, leading up to optimal operating conditions, namely, $\mathrm{NaOH}$ amount to be added to recover the most of $\mathrm{FePO}_{4}\left(7.5 \mathrm{ml}\right.$ of $\mathrm{NaOH}$ for a full removal of $\left.\mathrm{Fe}^{3+}\right)$ [141].

Then, electrolyte and salts are removed by vacuum distillation, and solvents and heat dissolve the binder. This enables the separation of the current collector foils from the electrode materials. After grinding, a leaching step follows to purify further the electrode materials and metals, which are extracted by precipitation or solvent extraction [92].

Christian Hanisch et al. proposed a novel strategy for the recycling used batteries, using thermal decomposition of PVDF binder, causing a weakening in the adhesion between the active materials in the electrode coating ink, and the current collector thin film. Then, the active materials in the coating ink are entirely separated from the current collector, by the technique created by the authors, called adhesion neutralisation via incineration and impact liberation (ANVIIL), which uses an air-jet-separator (Figure 14a). The most significant advantage of this method is the regaining of highly pure materials with a 
consistent and very similar size distribution [142]. In this process, it is possible to regain $97.1 \%$ of the coating $(0.1 \%$ of $\mathrm{Al}$ impurities $)$. It is claimed that the regained materials are 30 times purer than state-of-the-art ones [142].

A novel process based on the bipolar membrane electrodialysis and the metal-ion chelation has been reported. The effect of the initial ethylenediaminetetraacetic acid (EDTA) concentration (0.01-0.03 M) as chelating agent, at initial $\mathrm{pH} 7.0$ of $\mathrm{Na}^{+}$ion feed solution was studied. The $\mathrm{pH}$ of the feed solution slightly decreased for all EDTA concentrations. The addition of the EDTA to a combined solution of lithium and cobalt from spent LIBS, can lead up to very high selectiveness ratios 99\% [143].

The industry of solar cells manufacturing generates waste from silicon debris particles, produced during the cutting of silicon ingots, as thin wafers, for the construction of the photovoltaic cells, which are estimated in $40 \%$ of the mass of the ingots, that are not reused. Additionally, a silicon sludge waste is generated and needs to be recycled. These two waste materials can be reused, extracting the present silicon nanoparticles in the materials, by the aerosol assisted technique, and then recovered by ultrasonic spray drying (Figure 14b). This low-cost approach can positively value the waste materials by producing regenerated silicon anodes for LIBS [101, 103, 143]. 


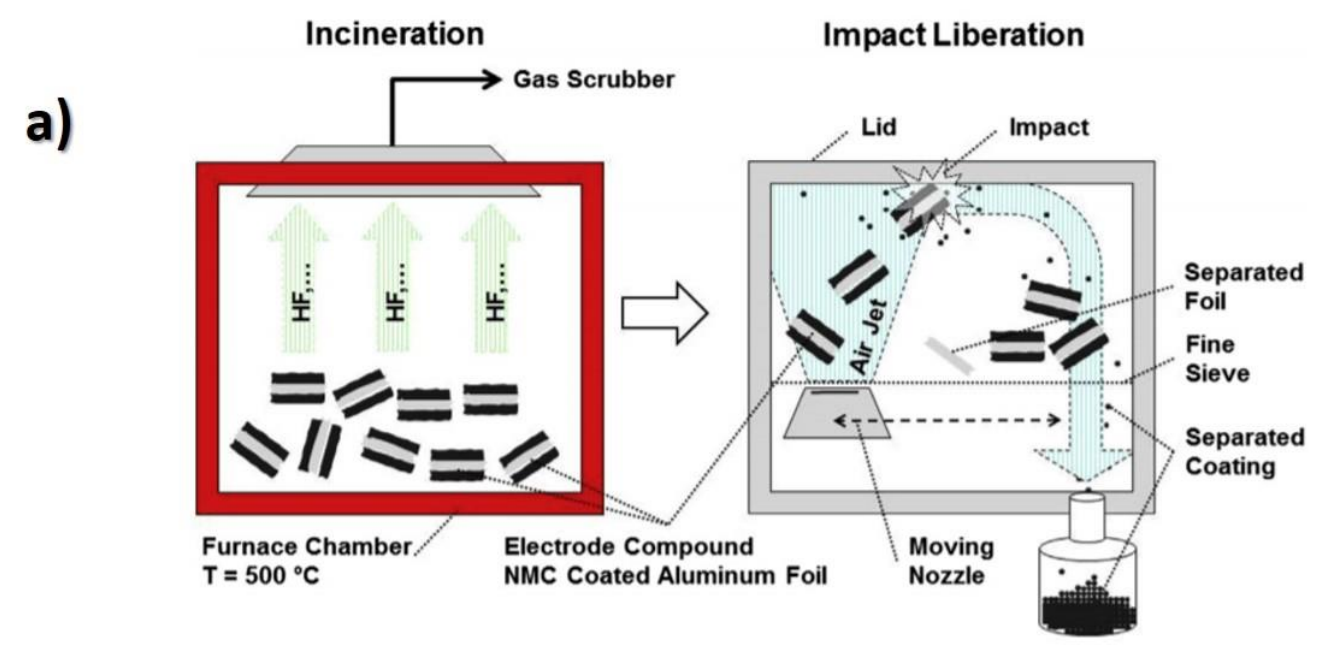

b)

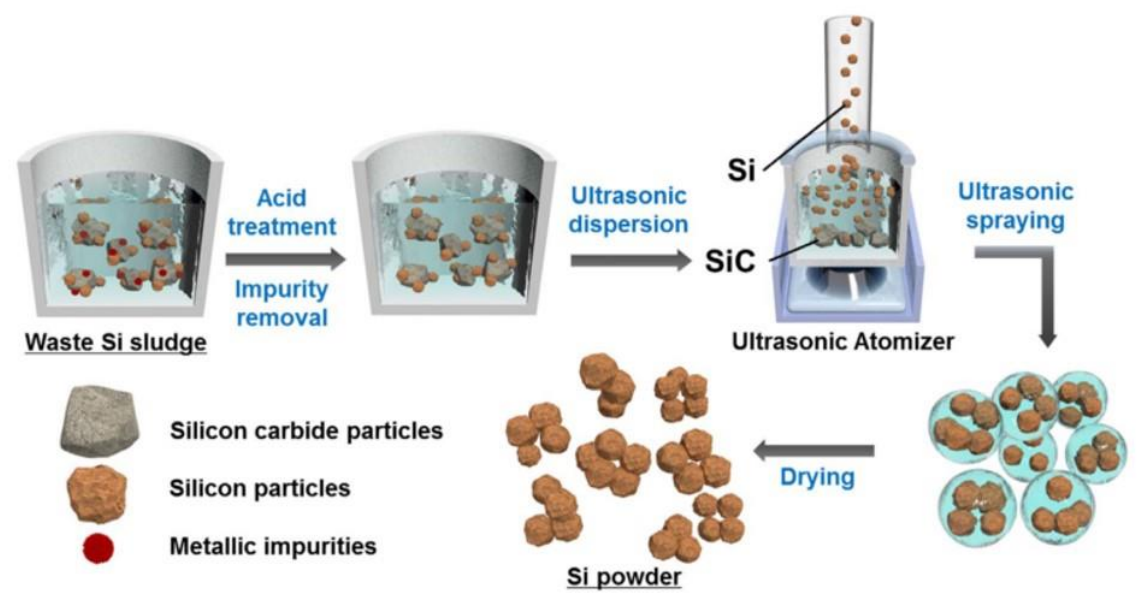

Figure 14 - a) Representation of the experimental process of adhesion neutralisation via incineration and impact liberation [142] and b) schematic representation of the proposed ultrasonic aerosol assisted silicon extraction method [144].

Cobalt from wasted LIBS can be recovered by solvent extraction and leaching, being recovered almost $99.9 \%$ of cobalt, from the solution of Cyanex 272 as extractant, isodecanol as phase modification and kerosene as diluent. One final product is a hydrated cobalt salt, prepared several evaporation steps, crystallisation, precipitation and cementation methods (¿Error! No se encuentra el origen de la referencia.15). 


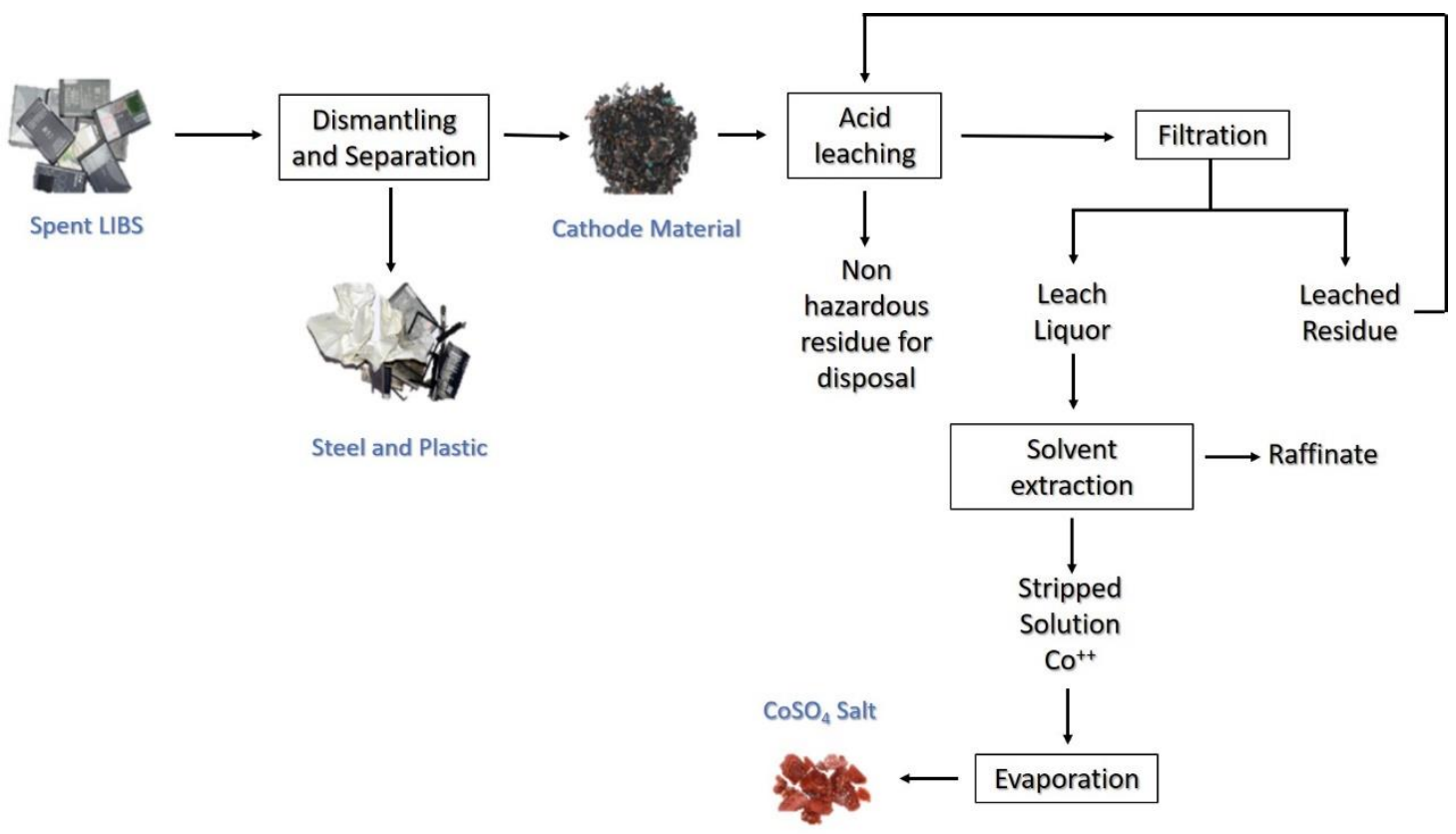

Figure 15 - Schematic representation of the several steps to recover cobalt from spent LIBS. Based on [145].

Considering the safety risks associated with the possibility of battery explosion during the recycling processes, some authors have proposed a method that prevents explosion during thermal treatments. This technique needs the use of a electric furnace with $\mathrm{SiC}$ heater in a temperature range of $300-600{ }^{\circ} \mathrm{C}$ for 2 hours, where it is possible to treat the wasted batteries under an inert argon atmosphere, leading to the safe recovery of electrode powders (32-35 wt.\% for Co and 3-5 wt.\% for Li) by further chemical leaching [146].

An interesting magnetic electrode was developed for LIBS to overcome the challenge of battery recycling. The magnetic properties can be achieved using magnetic $\mathrm{Fe}_{3} \mathrm{O}_{4}$ particles (dispersed and uniform size of $100 \mathrm{~nm}$ ) as an electrode. The magnetic susceptibilities of a mixed powder of $\mathrm{Fe}_{3} \mathrm{O}_{4}, \mathrm{LiFePO}_{4}$ and conductive agent (1:1:1) was evaluated with an external field between -1 and $1 \mathrm{~T}$, presenting a super-paramagnetic behaviour without remanence or coercivity. It is claimed that the produced batteries are easier to recycle and have a lower manufacturing cost. Also, the batteries exhibit some advantageous properties, as anti-vibration and non-fatigue behaviour, with excellent results even up to 1000 working cycles, perfect for hard conditions (anti-vibration and non-fatigue) engineering machines [147].

An experiment carried out with a multi-step process, done with several types of used and crushed LIBS, led to considerable recovery rates for aluminium, manganese, nickel, cobalt and lithium (97\%) [148]. The process consists of an alkali decomposition, followed 
by acid leaching. Then, the metals are precipitated individually, from the leach mixture, according to various $\mathrm{pH}$ levels. Initially, $\mathrm{Al}$ is recovered in a filtration process, with a 4.0 $\mathrm{M} \mathrm{NH}_{4} \mathrm{OH}$ solution. $\mathrm{Mn}$ is precipitated at $\mathrm{pH}$ 7.5, $\mathrm{Ni}$ is obtained at $\mathrm{pH} 9$ and at $\mathrm{pH} 11-12$ Co is precipitated. Finally, $\mathrm{Li}$ is obtained as $\mathrm{Li}_{2} \mathrm{CO}_{3}$ using a solution of $\mathrm{Na}_{2} \mathrm{CO}_{3}$ [148]. The scientific area of thermodynamics can serve as study base for the development of a novel strategy to optimise the recycling of LIBS. A study reports that, the hightemperature metal recovery process, which involves several steps, as material size reduction, chemical and thermal reduction, smelting and casting, needs to be improved, because it is associated with losses of energy (primarily in the smelting step). These losses are related to the conversion of electricity into heat, being considered energy dissipated and not used yet [149].

Mechanochemistry is a scientific discipline aiming to help in the progress of recycling LIBS. The mechanochemical process is a method were a chemical reaction is induced by direct adsorption of mechanical energy. That enables the recycling of some value metals (lead, gold, copper, lithium, cobalt, molybdenum and nickel), from various electronic devices including cathode ray tube funnel glass, fluorescent lamps, LCD screens, and also LIBS, with the advantage of avoiding the use of strong acids. However, despite the potential of this kind of process, its energy consumption and productivity need to be improved to make the process scalable [150].

Selective separation and recovery of some precious metals, like copper, cobalt and lithium, from the leachate of wasted LIB in acid chloride media with solvent impregnated resins, is reported as an effective method. The selectivity of the process is advantageous as it avoids the necessity to treat each electrode separately from its current collector (Al and $\mathrm{Cu}$ ), by remove the metals of both of them in the same process [151].

Yang Guo et al. proved that the hydrochloric acid $(\mathrm{HCl})$ leaching is an effective method to separate lithium and graphite from anodes. That work noted that leaching at $3 \mathrm{M} \mathrm{HCl}$ concentration for $80{ }^{\circ} \mathrm{C}$ for 90 minutes at a S/L ratio of 1:50 g.mll could lead to a maximum leaching efficiency of $99.4 \%$. Figure 16a shows the disassembly steps for the recycle of the lithium-ion anodes [152].

As part of an experiment, some $\mathrm{LiNi}_{1 / 3} \mathrm{Co}_{1 / 3} \mathrm{Mn}_{1 / 3} \mathrm{O}_{2}$ LIBS scraps were recycled by hydrogen and carbon reductive treatment and sulfur acid leaching, and then subject to solvent extraction, to recover $\mathrm{Co}, \mathrm{Ni}$ and $\mathrm{Mn}$ metals. For example, the use of oxidants such as potassium permanganate and chlorine dioxide can effectively remove $\mathrm{Mn}$, from the NCM solution [153]. 
In the recovery process of used LIBS from smartphones, it is necessary to dismantle and separate the electrodes from the steel casing and plastic. Then the electrodes are crushed, and the metals are recovered by leaching and solvent extraction steps (Figure 16b) [154]. Graphite recovery from wasted LIBS is possible due to a method, involving electrolyte extraction subcritical carbon dioxide, which is considered very promising because it leads to almost complete and efficient utilisation of all the entire components of the LIB. With this method, electrolyte can be recovered at an efficiency of $90 \%$, including the conductive salt [155]. Also, was demonstrated the ability to regain the capacity of a lithium iron phosphate $\left(\mathrm{LiFePO}_{4}\right)$ cathode using a functionalisation treatment based on re-lithiation techniques [156].

A new thermal treatment technique was investigated, to reuse the materials, giving the addition of avoiding the explosion behaviour (thermal runaway) and risks, during the recycling process, contributing to better sustainability. ¿Error! No se encuentra el origen de la referencia.16c represents the steps of the proposed recycling process, including the studied thermal treatment $\left(300-600{ }^{\circ} \mathrm{C}\right.$ for 2 hours), the crushing and sieving processes $(<105 \mu \mathrm{m})$, the hydrometallurgical process and magnetic separation. Cobalt and lithium were recovered at $49 \mathrm{wt} . \%$ and $4 \mathrm{wt} . \%$, respectively [157].

a)

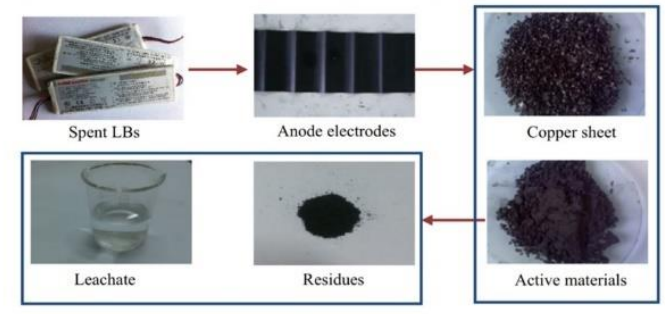

b)

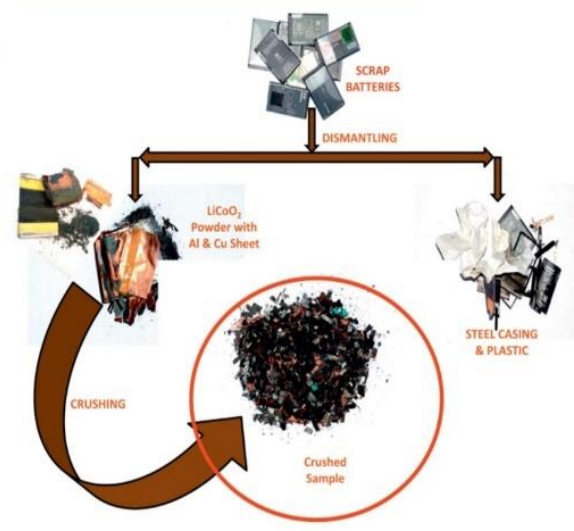

c) Li-ion battery scrap

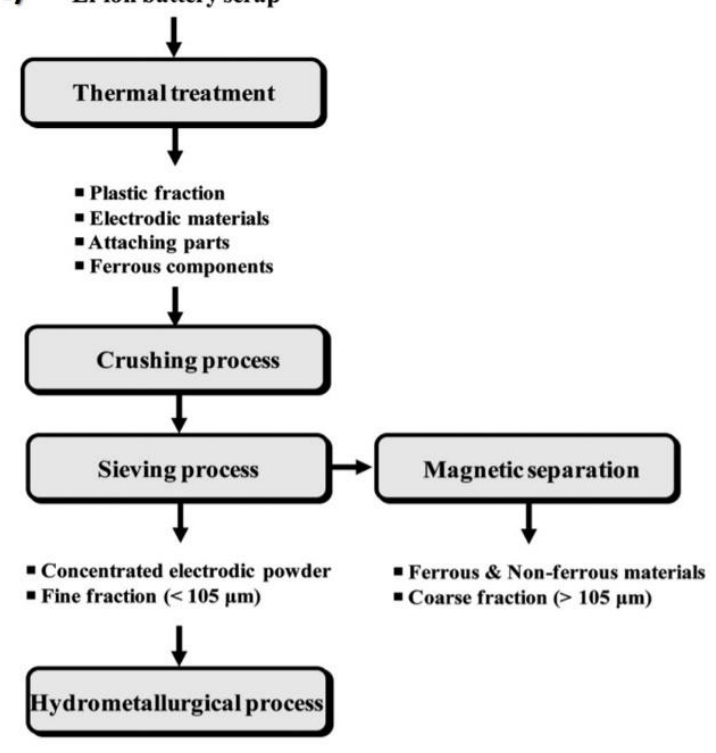

Figure 16 - a) Disassembly and recycling process of the active material from the anode of a wasted LIB [152]; b) process of sample recycling preparation from spent smartphones 
LIBS [154] and c) process flow of the thermal treatment method for recycling of spent LIBS [157].

An experiment carried out with an off-gas producing process, with extraction, drying and condensation was successfully reported, to study the influence on the exhaust gas flow, as well, as the composition, derivative of the drying and condensation variables. The higher performance proposed recycling process involves and combines several steps, such as the discharge, dismantling, shredding, extraction, drying and separation [158]. Future trend include the possibility to inject the electrode materials in the battery structure, which allow the reuse of the battery cell, leading to a significant reduction of recycling steps, necessary products, spent energy, and consequently the costs. The proof of concept for the envisioned strategy is shown for injectable batteries [159].

\subsection{Component-based recycling}

Alternatively, to whole-battery-based methods, most works reported to date focus on the development of highly specific processes addressing the recovery of material from a particular LIB component.

\subsubsection{Current collectors}

For any recycling process to work correctly, the active materials need to be separated from the metallic current collectors first. This can be achieved in acid baths. The acids react with the copper and aluminium thin films, weakening the adhesion of the active material to the current collector, and facilitating the separation [147]. Vacuum pyrolysis is an efficient separation technique that allows the reuse of the aluminium foils, by peeling the cathode materials from the current collector at efficiencies near $100 \%$ and without damaging it [160]. Heated ionic liquids have also been used to dissolve the binder from the cathode materials, which separates them from the current collector, allowing an efficient recover the aluminium foils [161]. The metallic portion of spent LIBs can be recycled using mechanical pre-treatments as mechanical shredding and size-based sorting steps. Each metal type can be segregated in different size fractions, facilitating the recycling process, and allowing a more efficient separation [162]. Effective pretreatments, such as crushing and sieving, proved to enhance the subsequent leaching treatments, with higher recovery efficiencies for the electrode powders [163]. Ultrasonic washing, with an ultrasonic frequency of $40 \mathrm{~Hz}$ and electric power of $100 \mathrm{~W}$, has been demonstrated to separate electrode materials, particularly $\mathrm{LiCoO}_{2}$ cathodes, from their 
support substrate, increasing the recover efficiency of Co and $\mathrm{Li}$ to $99 \%$ and $97 \%$, respectively, and reduced the overall energy needs and pollution of the process [164]. Ethylene glycol is an effective compound to delaminate electrode materials at low temperatures and separate them from the current collectors without damaging them [165].

\subsubsection{Recovery of cathode materials}

Most of the recycling efforts to date have focused on the cathode due to its higher content in lithium and other valuable metals. Five types of cathodes were studied by quantifying the natural resource output needed in the production of each one in a closed-loop scenario. The impact of composition, properties and production techniques of the different cathodes was also analysed. It was concluded that the main impact related to natural resources used were metal supply and energy used in the production of the cathodes. This study also showed the importance to evaluate every type of device individually, by taking into account the objectives and targets for each one of them [166].

The cathode is also the most challenging component to recycle, because of its structural complexity and the variety of active materials present. However, it is also the most studied component, with a growing number of studies made every year, through the publication of about 143 articles in 2019, which target recovery of lithium compounds but also other rare metal elements, such as cobalt, iron, manganese or nickel. The choice of the recycling method to use is dependent on the target metal to recover, because each method has different recovery efficiencies, usually making them more suitable for one type of material. Furthermore, attention is needed to properties of some metals, that can affect the efficiency of the process, leaving impurities in the structure of the recovered materials. For example, $\mathrm{Cu} \mathrm{Ni}, \mathrm{Co}$ and $\mathrm{Mn}$ metal ions, have similar solubilities which can leave some impurities in NCM batteries when chemical precipitation processes are used. These impurities can affect the efficiency of the recycled battery, more specifically $\mathrm{Cu}$ metal that can short circuit the cell, or $\mathrm{Cu}$ ions that can improve the discharge capacity [167]. Some procedures can be optimised to obtain high recovery efficiencies for several metals regardless of the active materials. A new low-temperature methodology with high efficiency has been proposed to recycle Li-ion batteries economically for mixed cathode materials, including $\mathrm{LiCoO}_{2}, \mathrm{LiMn}_{2} \mathrm{O}_{4}, \mathrm{LiNi}_{0.33} \mathrm{Mn}_{0.33} \mathrm{Co}_{0.33} \mathrm{O}_{2}$, and $\mathrm{LiFePO}_{4}$ were employed in the recovery process [168]. The process, schematised in Figure 17a, used $4 \mathrm{M}$ sulfuric acid and $30 \mathrm{wt} \%$ hydrogen peroxide $\left(2-3\right.$ hours at $\left.70-80^{\circ} \mathrm{C}\right)$ for leaching. 
Residual $\mathrm{LiFeO}_{4}$ was filtrated out at this step. Next, $\mathrm{pH}$ was adjusted to precipitate $\mathrm{Fe}(\mathrm{OH})_{3}$ while $\mathrm{Mn}^{2+}, \mathrm{Co}^{2+}$ and $\mathrm{Ni}^{2+}$ remain in solution. The concentrations of $\mathrm{Mn}^{2+}, \mathrm{Co}^{2+}$ and $\mathrm{Ni}^{2+}$, were determined, and their ratios adjusted to 1:1:1 with the addition of $\mathrm{CoSO}_{4}$, $\mathrm{NiSO}_{4}$, and $\mathrm{MnSO}_{4}$ (stirring for 2h). $\mathrm{pH}$ was increased to 11 (addition of $\mathrm{NaOH}$ ) and the mixture of $\mathrm{Co}(\mathrm{OH})_{2}, \mathrm{Ni}(\mathrm{OH})_{2}$ and $\mathrm{Mn}(\mathrm{OH})_{2}$ was co-precipitated. The solid mixture was then washed with distilled water. $\mathrm{Na}_{2} \mathrm{CO}_{3}$ was added to the solution $\left(40^{\circ} \mathrm{C}\right)$ and then proceeded to filtrate it and recover $\mathrm{Li}_{2} \mathrm{CO}_{3}$. The recovered materials were then used in the production of new cathode material $\left(\mathrm{LiNi}_{0.33} \mathrm{Mn}_{0.33} \mathrm{Co}_{0.33} \mathrm{O}_{2}\right)$. This process recovers almost $100 \%$ of $\mathrm{Ni}, \mathrm{Mn}, \mathrm{Co}$, and experiments demonstrate that about $80 \%$ of $\mathrm{Li}$ is recycled in the form of $\mathrm{Li}_{2} \mathrm{CO}_{3}[168]$.

Figure $17 \mathrm{~b}$ summarises a closed-loop process reported to recover lithium carbonate from cathode scrap of LIB.
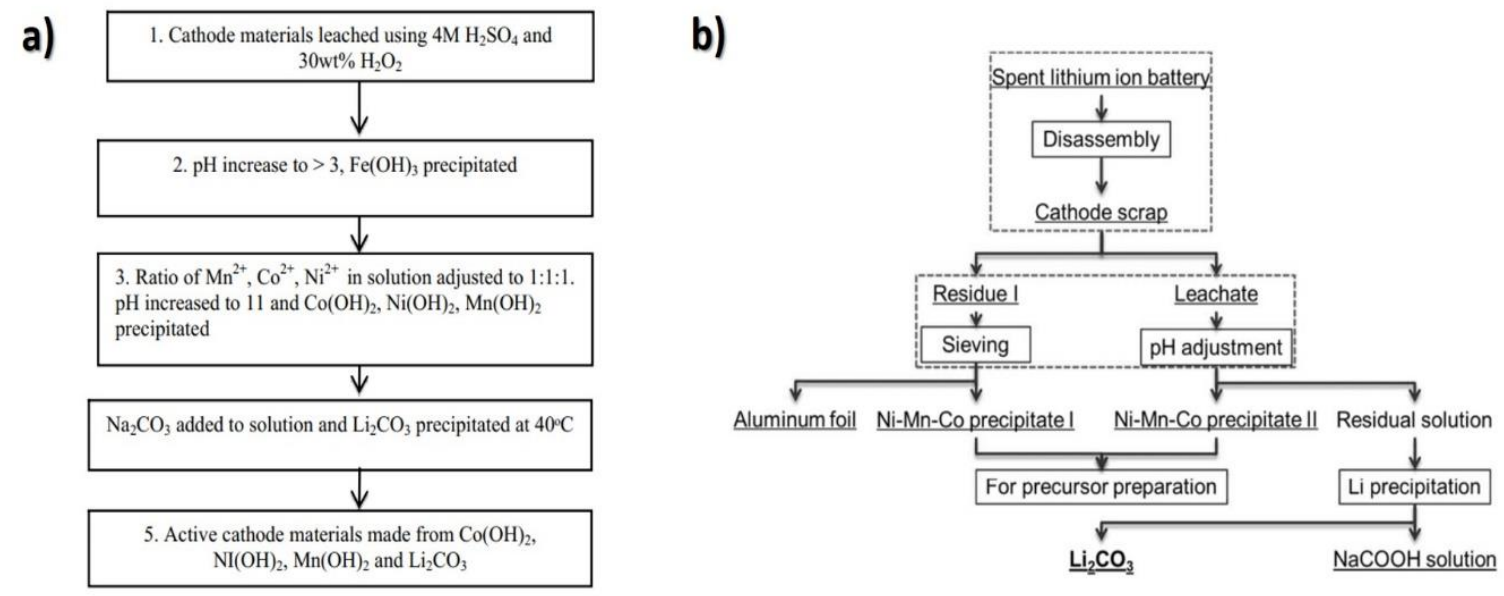

Figure 17 - a) Flow chart for separation and synthesis process for mixed cathode material [168] and b) simplified flow-sheet of the recovery process based on formic acid [169].

Lithium could be selectively leached into solution using formic acid while aluminium remained as metallic form, and most of the other metals from the cathode scrap could be precipitated out [169]. The separation of the remaining Ni, Co and $\mathrm{Mn}$ from the leachate, $\mathrm{Li}_{2} \mathrm{CO}_{3}$ with a purity of $99.90 \%$ could be obtained. The final solution after lithium carbonate extraction can be further processed for sodium formate preparation and $\mathrm{Ni}, \mathrm{Co}$ and $\mathrm{Mn}$ precipitates are ready for precursor preparation for cathode materials. As a result, the global recovery rates of $\mathrm{Al}, \mathrm{Li}, \mathrm{Ni}, \mathrm{Co}$ and $\mathrm{Mn}$ reported were $95.46 \%, 98.22 \%$, 
$99.96 \%, 99.96 \%$ and $99.95 \%$ respectively, achieving the effective recycling of materials from cathode scrap of spent LIBs [169].

Other authors created a closed-loop recycling process where new cathode materials can be made from spent LIBS. They used spent LIBs primarily composed of $\mathrm{LiCoO}_{2}$ and, in a second experiment, cathode materials with $\mathrm{LiMn}_{2} \mathrm{O}_{4}, \mathrm{LiNi}_{0.33} \mathrm{Mn}_{0.33} \mathrm{Co}_{0.33} \mathrm{O}_{2}$ and $\mathrm{LiFePO}_{4}$ powders added to the shredded used batteries. In both cases the batteries are discharged, then shredded. The steel casing is removed from the shredded material by magnetic separation. Cathode materials are separated from the aluminium current collectors by dissolving the aluminium in $\mathrm{NaOH}$. Next, the remaining cathode powders were then separated by sieving. Last, copper current collectors were separated from the remaining material, mainly plastic, by density separation. The recovery efficiencies of this process are reportedly close to $90 \%$ [170]. Acid leaching processes were optimized to effectively recover $\mathrm{Ni}, \mathrm{Li}, \mathrm{Mn}$ and Co materials. The combination of different acetic and ascorbic acid concentrations leads to different leaching efficiencies. Under optimal conditions over $95 \%$ of the total leached metals can be recovered [171].

Table 3 presents a comprehensive list of the different methods used to recycle and recover cathode materials, highlighting their main advantages and disadvantages

Table 3 - Summary of cathode recycling processes reported in the literature. 


\begin{tabular}{|c|c|c|c|c|c|c|c|}
\hline Initial material & Process & Conditions & $\begin{array}{l}\text { Obtained } \\
\text { Material }\end{array}$ & $\begin{array}{c}\text { Efficiency } \\
(\%)\end{array}$ & Advantages & Disadvantages & Ref \\
\hline $\mathrm{LiCoO}_{2}$ & Acid leaching & $\begin{array}{c}\text { Addition of } \\
\mathrm{HCl}\end{array}$ & $\mathrm{Co}, \mathrm{Li}$ & $\sim 100$ & \begin{tabular}{|c|} 
High \\
recovery \\
efficiencies
\end{tabular} & $\begin{array}{l}\text { Use of toxic } \\
\text { reagents }\end{array}$ & [172] \\
\hline $\mathrm{LiCoO}_{2}$ & Acid leaching & $\begin{array}{l}\text { Addition of } \\
\mathrm{HCl} \text { and } \\
\mathrm{NaOH}\end{array}$ & $\mathrm{Li}, \mathrm{Co}$ & - & $\begin{array}{c}\text { Environmen } \\
\text { tally } \\
\text { friendly } \\
\end{array}$ & $\begin{array}{c}\text { High } \\
\text { temperatures } \\
\text { needed } \\
\end{array}$ & [173] \\
\hline \multirow[b]{2}{*}{$\mathrm{LiCoO}_{2}$} & \multirow[b]{2}{*}{ Acid leaching } & \multirow{2}{*}{$\begin{array}{c}\text { Addition of } \\
\mathrm{H}_{3} \mathrm{PO}_{4}\end{array}$} & $\mathrm{Co}_{3}\left(\mathrm{PO}_{4}\right)_{2}$ & 99 & \multirow{2}{*}{$\begin{array}{c}\text { High purity } \\
\text { of recovered } \\
\text { materials }\end{array}$} & \multirow{2}{*}{$\begin{array}{l}\text { Use of toxic } \\
\text { reagents }\end{array}$} & \multirow[b]{2}{*}{ [174] } \\
\hline & & & $\mathrm{Li}$ & 99 & & & \\
\hline \multirow[b]{2}{*}{$\mathrm{LiCoO}_{2}$} & \multirow[b]{2}{*}{ Acid leaching } & \multirow{2}{*}{$\begin{array}{c}\text { Addition of } \\
\mathrm{H}_{3} \mathrm{PO}_{4}\end{array}$} & $\mathrm{Co}$ & 98 & \multirow{2}{*}{$\begin{array}{l}\text { High } \\
\text { recovery } \\
\text { rates }\end{array}$} & \multirow{2}{*}{$\begin{array}{c}\text { High } \\
\text { temperatures } \\
\text { needed }\end{array}$} & \multirow[b]{2}{*}{ [175] } \\
\hline & & & $\mathrm{Li}$ & 97 & & & \\
\hline \multirow[b]{2}{*}{$\mathrm{LiCoO}_{2}$} & \multirow[b]{2}{*}{ Acid leaching } & \multirow[b]{2}{*}{$\begin{array}{c}\text { Addition of } \\
\text { glucose and } \\
\mathrm{H}_{3} \mathrm{PO}_{4}\end{array}$} & Co & 98 & \multirow{2}{*}{$\begin{array}{c}\text { Environmen } \\
\text { tally } \\
\text { friendly } \\
\text { process }\end{array}$} & \multirow[b]{2}{*}{$\begin{array}{l}\text { Requires high } \\
\text { temperatures }\end{array}$} & \multirow[b]{2}{*}[176]{} \\
\hline & & & $\mathrm{Li}$ & $\sim 100$ & & & \\
\hline $\mathrm{LiCoO}_{2}$ & Acid leaching & $\begin{array}{c}\text { reaction time } \\
2.5 \mathrm{~h}, \mathrm{H}_{2} \mathrm{O}_{2} \\
\text { dosage } 1.6 \\
\mathrm{~mL}^{-1} \mathrm{~g}^{-1}, \\
\mathrm{H}_{2} \mathrm{SO}_{4} \\
\text { concentratio } \\
\mathrm{n} \\
3.0 \mathrm{~mol}^{-1} \mathrm{~L}^{-1}, \\
\text { reaction } \\
\text { temperature } \\
70{ }^{\circ} \mathrm{C} \text {, and } \\
\text { the dosage of } \\
\mathrm{H}_{2} \mathrm{SO}_{4} 7.0 \\
\mathrm{~mL} \mathrm{~g}-1 .^{-}\end{array}$ & Co & 99.5 & $\begin{array}{l}\text { High purity } \\
\text { of cobalt }\end{array}$ & $\begin{array}{l}\text { Acid use and } \\
\text { high } \\
\text { temperatures }\end{array}$ & [177] \\
\hline $\mathrm{LiCoO}_{2}$ & Acid leaching & $\begin{array}{c}\text { Addition of } \\
\mathrm{H}_{2} \mathrm{SO}_{4} \text { and } \\
\mathrm{H}_{2} \mathrm{O}_{2}\end{array}$ & $\mathrm{CoOH}_{2}$ & - & \begin{tabular}{|c|} 
Good \\
electrochem \\
ical \\
performance \\
\end{tabular} & $\begin{array}{l}\text { Requires high } \\
\text { temperatures }\end{array}$ & [178] \\
\hline \multirow[b]{2}{*}{$\mathrm{LiCoO}_{2}$} & \multirow[b]{2}{*}{ Acid leaching } & \multirow{2}{*}{$\begin{array}{c}\text { Addition of } \\
\mathrm{H}_{2} \mathrm{SO}_{4} \text { and } \\
\text { Cyanex } 272\end{array}$} & Co & 93 & \multirow{2}{*}{$\begin{array}{c}\text { High purity } \\
\text { cobalt } \\
\text { obtained }\end{array}$} & \multirow{2}{*}{$\begin{array}{l}\text { Use of toxic } \\
\text { reagents }\end{array}$} & \multirow[b]{2}{*}{ [179] } \\
\hline & & & $\mathrm{Li}$ & 94 & & & \\
\hline \multirow[b]{2}{*}{$\mathrm{LiCoO}_{2}$} & \multirow[b]{2}{*}{ Acid leaching } & \multirow{2}{*}{$\begin{array}{c}\text { Addition of } \\
\mathrm{H}_{2} \mathrm{SO}_{4} \\
\text { Acorga } \\
\text { M5640 and } \\
\text { Cyanex } 272\end{array}$} & $\mathrm{Cu}$ & 98 & \multirow[b]{2}{*}{$\begin{array}{l}\text { High } \\
\text { recovery } \\
\text { rates }\end{array}$} & \multirow[b]{2}{*}{$\begin{array}{l}\text { Use of toxic } \\
\text { reagents }\end{array}$} & \multirow[b]{2}{*}{ [180] } \\
\hline & & & Co & 97 & & & \\
\hline $\mathrm{LiCoO}_{2}$ & Acid leaching & $\begin{array}{l}1.5 \mathrm{M} \text { DL- } \\
\text { malic acid, } \\
2.0 \text { vol. } \% \\
\text { hydrogen } \\
\text { peroxide, a } \\
\text { leaching }\end{array}$ & $\mathrm{Co}$ & 96 & $\begin{array}{l}\text { High metal } \\
\text { recovery } \\
\text { rate }\end{array}$ & $\begin{array}{c}\text { Toxic materials, } \\
\text { high } \\
\text { temperatures }\end{array}$ & [110] \\
\hline
\end{tabular}




\begin{tabular}{|c|c|c|c|c|c|c|c|}
\hline & & $\begin{array}{c}\text { temperature } \\
\text { of } 90{ }^{\circ} \mathrm{C} \text {, an } \\
\mathrm{S}: \mathrm{L} \text { ratio of } \\
20 \mathrm{~g} . \mathrm{L}^{-1} \\
\text { and a time } \\
\text { interval of } \\
40 \mathrm{~min}\end{array}$ & & & & & \\
\hline $\mathrm{LiCoO}_{2}$ & Acid leaching & $\begin{array}{l}\text { Addition of } \\
\text { malic acid } \\
\text { and oxalic } \\
\text { acid }\end{array}$ & $\mathrm{CoC}_{2} \mathrm{O}_{4}$ & 99 & $\begin{array}{l}\text { Simple } \\
\text { process }\end{array}$ & $\begin{array}{c}\text { High } \\
\text { temperatures } \\
\text { needed }\end{array}$ & [181] \\
\hline $\mathrm{LiCoO}_{2}$ & Acid leaching & $\begin{array}{l}\text { Addition of } \\
\text { Cyanex } 272\end{array}$ & $\mathrm{Co}$ & $\sim 100$ & $\begin{array}{c}\text { Almost full } \\
\text { recovery of } \\
\text { Co }\end{array}$ & $\begin{array}{l}\text { Cyanex } 272 \\
\text { requires much } \\
\text { care }\end{array}$ & [182] \\
\hline $\mathrm{LiCoO}_{2}$ & Acid leaching & $\begin{array}{c}\text { Addition of } \\
\text { D2HEPA } \\
\text { and Cyanex } \\
272\end{array}$ & $\begin{array}{l}\mathrm{Co}, \mathrm{Cu}, \\
\mathrm{Mn}, \mathrm{Al}\end{array}$ & $\sim 100$ & $\begin{array}{c}\text { Easily } \\
\text { adaptable to } \\
\text { different } \\
\text { LIB } \\
\text { technologies } \\
\end{array}$ & $\begin{array}{l}\text { Many steped } \\
\text { process }\end{array}$ & [183] \\
\hline $\mathrm{LiCoO}_{2}$ & Acid leaching & $\begin{array}{l}\text { Addition of } \\
\text { nitric acid }\end{array}$ & $\mathrm{LiCoO}_{2}$ & - & $\begin{array}{c}\text { Good } \\
\text { Cycling } \\
\text { performance }\end{array}$ & $\begin{array}{l}\text { Use of toxic } \\
\text { reagents }\end{array}$ & [184] \\
\hline \multirow[b]{2}{*}{$\mathrm{LiCoO}_{2}$} & \multirow[b]{2}{*}{ Acid leaching } & \multirow{2}{*}{$\begin{array}{c}\text { Addition of } \\
\text { citric acid } \\
\text { and } \mathrm{H}_{2} \mathrm{O}_{2}\end{array}$} & $\mathrm{Co}$ & 90 & \multirow{2}{*}{$\begin{array}{l}\text { High } \\
\text { recovery } \\
\text { rate for } \mathrm{Li}\end{array}$} & \multirow{2}{*}{$\begin{array}{l}\text { Low recovery } \\
\text { rate for Co }\end{array}$} & \multirow[b]{2}{*}{ [185] } \\
\hline & & & $\mathrm{Li}$ & $\sim 100$ & & & \\
\hline \multirow[b]{2}{*}{$\mathrm{LiCoO}_{2}$} & \multirow[b]{2}{*}{ Acid leaching } & \multirow{2}{*}{$\begin{array}{l}\text { Addition of } \\
\text { citric acid; } \\
\text { ultrasonic } \\
\text { agitation }\end{array}$} & $\mathrm{Co}$ & 96 & \multirow{2}{*}{$\begin{array}{c}\text { Environmen } \\
\text { tally } \\
\text { friendly }\end{array}$} & \multirow[b]{2}{*}{$\begin{array}{l}\text { Few metals } \\
\text { recovered }\end{array}$} & \multirow[b]{2}{*}{ [170] } \\
\hline & & & $\mathrm{Li}$ & $\sim 100$ & & & \\
\hline \multirow{4}{*}{$\mathrm{LiCoO}_{2}$} & \multirow{4}{*}{ Acid leaching } & \multirow{4}{*}{$\begin{array}{l}\text { Addition of } \\
\text { citric acid } \\
\text { (from citrus } \\
\text { juice); }\end{array}$} & $\mathrm{Li}$ & $\sim 100$ & \multirow{4}{*}{$\begin{array}{c}\text { Environmen } \\
\text { tally } \\
\text { friendly }\end{array}$} & \multirow{4}{*}{$\begin{array}{l}\text { Complex } \\
\text { process }\end{array}$} & \multirow{4}{*}{ [186] } \\
\hline & & & $\mathrm{Mn}$ & 99 & & & \\
\hline & & & $\mathrm{Ni}$ & 98 & & & \\
\hline & & & $\mathrm{Co}$ & 94 & & & \\
\hline \multirow[b]{2}{*}{$\mathrm{LiCoO}_{2}$} & \multirow[b]{2}{*}{ Acid leaching } & \multirow{2}{*}{$\begin{array}{c}\text { Addition of } \\
\text { mild organic } \\
\text { acids } \\
\text { (iminodiaceti } \\
\text { c and } \\
\text { maleic) }\end{array}$} & $\mathrm{Li}$ & 99 & \multirow[b]{2}{*}{$\begin{array}{c}\text { Environmen } \\
\text { tally } \\
\text { friendly }\end{array}$} & \multirow[b]{2}{*}{$\begin{array}{l}\text { Low Cobalt } \\
\text { recovery rate }\end{array}$} & \multirow[b]{2}{*}{ [187] } \\
\hline & & & $\mathrm{Co}$ & 91 & & & \\
\hline \multirow[b]{2}{*}{$\mathrm{LiCoO}_{2}$} & \multirow[b]{2}{*}{ Acid leaching } & \multirow[b]{2}{*}{$\begin{array}{c}\text { Addition of } \\
\mathrm{HNO}_{3}\end{array}$} & $\mathrm{Li}$ & 85 & \multirow[b]{2}{*}{$\begin{array}{c}\text { Good } \\
\text { electrochem } \\
\text { ical } \\
\text { performance } \\
\text { of the } \\
\text { recovered } \\
\text { material }\end{array}$} & \multirow[b]{2}{*}{$\begin{array}{l}\text { Low recovery } \\
\text { efficiencies }\end{array}$} & \multirow[b]{2}{*}[58]{} \\
\hline & & & $\mathrm{Co}$ & 85 & & & \\
\hline \multirow{4}{*}{$\mathrm{LiCoO}_{2}$} & \multirow{4}{*}{$\begin{array}{l}\text { Mechanoche } \\
\text { mical } \\
\text { pretreatment/l }\end{array}$} & \multirow{4}{*}{$\begin{array}{l}\text { Magnetic } \\
\text { stirring; } \\
\text { constant }\end{array}$} & $\mathrm{Li}$ & 77 & \multirow{4}{*}{$\begin{array}{c}\text { Low energy } \\
\text { consumptio } \\
n\end{array}$} & \multirow{4}{*}{$\begin{array}{l}\text { Low efficiency } \\
\text { for lithium } \\
\text { recovery }\end{array}$} & \\
\hline & & & $\mathrm{Co}$ & 91 & & & [188] \\
\hline & & & $\mathrm{Mn}$ & 100 & & & \\
\hline & & & $\mathrm{Ni}$ & 99 & & & \\
\hline
\end{tabular}




\begin{tabular}{|c|c|c|c|c|c|c|c|}
\hline & $\begin{array}{l}\text { eaching with } \\
\mathrm{HNO}_{3}\end{array}$ & $\begin{array}{c}\text { temperature } \\
\left(25^{\circ} \mathrm{C}\right)\end{array}$ & & & & & \\
\hline \multirow[b]{2}{*}{$\mathrm{LiCoO}_{2}$} & \multirow{2}{*}{$\begin{array}{l}\text { Ultrasonic } \\
\text { treatment; } \\
\text { acid } \\
\text { dissolution; } \\
\text { precipitation }\end{array}$} & \multirow[b]{2}{*}{$\begin{array}{l}\text { Use of } \\
\mathrm{H}_{2} \mathrm{SO}_{4}\end{array}$} & $\mathrm{Li}$ & 95 & \multirow[b]{2}{*}{$\begin{array}{l}\text { High } \\
\text { recovery } \\
\text { efficiency }\end{array}$} & \multirow[b]{2}{*}{$\begin{array}{c}\text { High } \\
\text { temperatures } \\
\text { needed }\end{array}$} & \multirow[b]{2}{*}{ [189] } \\
\hline & & & Co & 99 & & & \\
\hline $\mathrm{LiCoO}_{2}$ & $\begin{array}{l}\text { Re-synthesis } \\
\text { by acid } \\
\text { leaching and } \\
\text { calcination }\end{array}$ & $\begin{array}{l}\text { Addition of } \\
\text { citric acid; } \\
\text { calcination } \\
\text { at } 450^{\circ} \mathrm{C}\end{array}$ & $\mathrm{LiCoO}_{2}$ & - & $\begin{array}{l}\text { Almost the } \\
\text { same } \\
\text { performance } \\
\text { when } \\
\text { compared } \\
\text { with the } \\
\text { original } \\
\text { materials }\end{array}$ & $\begin{array}{c}\text { High } \\
\text { temperatures } \\
\text { needed }\end{array}$ & [190] \\
\hline $\mathrm{LiCoO}_{2}$ & $\begin{array}{l}\text { Re-synthesis } \\
\text { by vacuum- } \\
\text { assisted heat- } \\
\text { treating and } \\
\text { solid-state } \\
\text { reaction }\end{array}$ & $\begin{array}{l}\text { Heat } \\
\text { treatment in } \\
\text { vacuum at } \\
600^{\circ} \mathrm{C} ;\end{array}$ & $\mathrm{LiCoO}_{2}$ & - & $\begin{array}{l}\text { Simple } \\
\text { process }\end{array}$ & $\begin{array}{l}\text { Low discharge } \\
\text { capacity of } \\
\text { synthesised } \\
\text { materials }\end{array}$ & [191] \\
\hline $\mathrm{LiCoO}_{2}$ & $\begin{array}{l}\text { Hydrothermal } \\
\text { reaction }\end{array}$ & $\begin{array}{l}\text { Immersion } \\
\text { in LiOH } \\
\text { solution, at } \\
200^{\circ} \mathrm{C}\end{array}$ & $\mathrm{LiCoO}_{2}$ & - & $\begin{array}{c}\text { Allows } \\
\text { separation } \\
\text { and } \\
\text { renovation } \\
\text { in one step }\end{array}$ & $\begin{array}{l}\text { Full separation } \\
\text { is not achieved }\end{array}$ & [192] \\
\hline $\mathrm{LiCoO}_{2}$ & $\begin{array}{l}\text { Grinding; } \\
\text { water } \\
\text { leaching }\end{array}$ & $\begin{array}{l}\text { Addition of } \\
\text { waste PVC }\end{array}$ & $\begin{array}{c}\mathrm{LiCl}, \\
\mathrm{CoFe}_{4} \mathrm{O}_{6}\end{array}$ & - & Low cost & $\begin{array}{l}\text { Low Co } \\
\text { recovery } \\
\text { efficiency }\end{array}$ & [193] \\
\hline $\mathrm{LiCoO}_{2}$ & $\begin{array}{l}\text { Ultrasonic } \\
\text { radiation }\end{array}$ & $\begin{array}{l}\text { Addition of } \\
\text { LiOH; } \\
\text { ultrasonic } \\
\text { power=800 } \\
\text { W }\end{array}$ & $\mathrm{LiCoO}_{2}$ & - & $\begin{array}{l}\text { Simple } \\
\text { method }\end{array}$ & $\begin{array}{l}\text { High energy } \\
\text { consumption }\end{array}$ & [194] \\
\hline $\mathrm{LiCoO}_{2}$ & $\begin{array}{l}\text { Thermal } \\
\text { decompositio } \\
\text { n; solid-state } \\
\text { reaction }\end{array}$ & $\begin{array}{l}\text { Decompositi } \\
\text { on at } 700^{\circ} \mathrm{C}\end{array}$ & $\mathrm{LiCoO}_{2}$ & - & $\begin{array}{c}\text { Effective } \\
\text { recovery of } \\
\text { nonstoichio } \\
\text { metric, } \\
\text { disordered } \\
\text { and } \\
\text { deformed } \\
\text { materials } \\
\end{array}$ & $\begin{array}{l}\text { Requires high } \\
\text { temperatures }\end{array}$ & [126] \\
\hline $\mathrm{LiCoO}_{2}$ & $\begin{array}{l}\text { Supercritical } \\
\quad \text { fluid } \\
\text { extraction }\end{array}$ & $\begin{array}{c}\text { Addition of } \\
\text { supercritical } \\
\mathrm{CO}_{2}\end{array}$ & Co & 95 & $\begin{array}{c}\text { Reduces the } \\
\text { amount of } \\
\mathrm{H}_{2} \mathrm{O}_{2} \\
\text { needed }\end{array}$ & $\begin{array}{c}\text { Energy } \\
\text { demanding }\end{array}$ & [195] \\
\hline $\mathrm{LiCoO}_{2}$ & $\begin{array}{l}\text { Electrodeposi } \\
\text { tion }\end{array}$ & $\begin{array}{c}\mathrm{pH}=5.4 ; \\
\text { potential of - } \\
1 \mathrm{~V}\end{array}$ & Co & 96 & $\begin{array}{l}\text { Simple } \\
\text { method }\end{array}$ & $\begin{array}{c}\text { Energy } \\
\text { demanding }\end{array}$ & [196] \\
\hline
\end{tabular}




\begin{tabular}{|c|c|c|c|c|c|c|c|}
\hline \multirow{4}{*}{$\mathrm{LiCoO}_{2}$} & \multirow{4}{*}{$\begin{array}{l}\text { Smelting } \\
\text { reduction }\end{array}$} & \multirow{4}{*}{$\begin{array}{c}1550^{\circ} \mathrm{C} \text { in } \\
\mathrm{Ar} \\
\text { atmosphere, } \\
\text { Addition of } \\
\mathrm{CaF}_{2} \text { and } \\
\mathrm{CaCl}_{2}\end{array}$} & Co & 99 & \multirow{4}{*}{$\begin{array}{l}\text { High } \\
\text { recovery } \\
\text { efficiency }\end{array}$} & \multirow{4}{*}{$\begin{array}{c}\text { High } \\
\text { temperatures } \\
\text { needed }\end{array}$} & \multirow{4}{*}{ [197] } \\
\hline & & & $\mathrm{Ni}$ & 99 & & & \\
\hline & & & $\mathrm{Mn}$ & 99 & & & \\
\hline & & & $\mathrm{Li}$ & 99 & & & \\
\hline $\mathrm{LiCoO}_{2}$ & $\begin{array}{l}\text { Solvent } \\
\text { method }\end{array}$ & $\begin{array}{l}\text { Addition of } \\
\text { DMF; } \\
\text { thermal } \\
\text { treatment at } \\
300^{\circ} \mathrm{C}\end{array}$ & $\mathrm{LiCoO}_{2}$ & - & Low cost & $\begin{array}{c}\text { High } \\
\text { temperatures } \\
\text { needed }\end{array}$ & [198] \\
\hline $\mathrm{LiCoO}_{2}$ & $\begin{array}{l}\text { Spouted bed } \\
\text { elutriation }\end{array}$ & $\begin{array}{c}\text { Air velocity } \\
\text { from } 1 \text { to } 21 \\
\mathrm{~m} / \mathrm{s}\end{array}$ & $\mathrm{LiCoO}_{2}$ & - & Inexpensive & $\begin{array}{l}\text { Low recovery } \\
\text { efficiency }\end{array}$ & [199] \\
\hline \multirow{3}{*}{$\mathrm{LiCoO}_{2}$} & \multirow{3}{*}{$\begin{array}{c}\text { Mineral } \\
\text { processing }\end{array}$} & \multirow{3}{*}{$\begin{array}{l}\text { Crushing; } \\
\text { sieving }\end{array}$} & $\mathrm{Cu}$ & 90 & \multirow{3}{*}{$\begin{array}{l}\text { No need for } \\
\text { chemical } \\
\text { solutions }\end{array}$} & \multirow{3}{*}{$\begin{array}{c}\text { Energy } \\
\text { demanding }\end{array}$} & \multirow{3}{*}{ [200] } \\
\hline & & & $\mathrm{Co}$ & 94 & & & \\
\hline & & & $\mathrm{Al}$ & 94 & & & \\
\hline $\mathrm{LiCoO}_{2}, \mathrm{CoO}$ & $\begin{array}{l}\text { Vacuum } \\
\text { pyrolysis; } \\
\text { Oxalate } \\
\text { leaching }\end{array}$ & $\begin{array}{c}\text { High } \\
\text { temperatures } \\
; \\
\text { Addition of } \\
\text { Oxalate and } \\
\mathrm{H}_{2} \mathrm{O}_{2} ; \\
\end{array}$ & $\begin{array}{c}\mathrm{CoC}_{2} \mathrm{O}_{4} \cdot 2 \mathrm{H} \\
{ }_{2} \mathrm{O}\end{array}$ & 98 & $\begin{array}{c}\text { Environmen } \\
\text { tally } \\
\text { compatible }\end{array}$ & $\begin{array}{l}\text { High energy } \\
\text { consumption }\end{array}$ & [201] \\
\hline \multirow{4}{*}{$\mathrm{LiCoO}_{2}$, graphite } & \multirow{4}{*}{$\begin{array}{l}\text { Assisted } \\
\text { flotation }\end{array}$} & \multirow{4}{*}{$\begin{array}{l}\text { Addition of } \\
\text { Fenton } \\
\text { reagent }\end{array}$} & $\mathrm{Co}$ & 99 & \multirow{4}{*}{$\begin{array}{c}\text { Allows } \\
\text { simultaneou } \\
\text { s recovery } \\
\text { of anode } \\
\text { and cathode } \\
\text { materials }\end{array}$} & \multirow{4}{*}{$\begin{array}{l}\text { The separation } \\
\text { process is not } \\
\text { very effective }\end{array}$} & \multirow{4}{*}{ [202] } \\
\hline & & & $\mathrm{Mn}$ & 89 & & & \\
\hline & & & $\mathrm{Cu}$ & 95 & & & \\
\hline & & & $\mathrm{Al}$ & 88 & & & \\
\hline $\mathrm{LiFePO}_{4}$ & Acid leaching & $\begin{array}{c}\text { Addition of } \\
\mathrm{H}_{3} \mathrm{PO}_{4}\end{array}$ & $\begin{array}{c}\mathrm{FePO}_{4} \cdot 2 \mathrm{H}_{2} \\
\mathrm{O}\end{array}$ & 75 & $\begin{array}{l}\text { Recovered } \\
\text { materials } \\
\text { with good } \\
\text { electrochem } \\
\text { ical } \\
\text { performance }\end{array}$ & $\begin{array}{c}\text { Low recovery } \\
\text { efficiency }\end{array}$ & [203] \\
\hline \multirow{5}{*}{$\mathrm{LiFePO}_{4}$} & \multirow{5}{*}{ Acid leaching } & \multirow{5}{*}{$\begin{array}{l}\text { Addition of } \\
\text { citric and } \\
\text { malic acid }\end{array}$} & $\mathrm{Li}$ & 95 & \multirow{5}{*}{$\begin{array}{c}\text { Environmen } \\
\text { tally } \\
\text { friendly }\end{array}$} & \multirow{5}{*}{$\begin{array}{l}\text { Multistep } \\
\text { process }\end{array}$} & \multirow{5}{*}{ [204] } \\
\hline & & & $\mathrm{Cu}$ & 97 & & & \\
\hline & & & $\mathrm{Al}$ & 47 & & & \\
\hline & & & $\mathrm{Fe}$ & 4 & & & \\
\hline & & & $\mathrm{P}$ & 1 & & & \\
\hline $\mathrm{LiFePO}_{4}$ & Acid leaching & & $\mathrm{Li}$ & 95 & & & [205] \\
\hline
\end{tabular}




\begin{tabular}{|c|c|c|c|c|c|c|c|}
\hline & & \begin{tabular}{|c|} 
Addition of \\
methyl \\
sulfonic and \\
p-toluene \\
sulfonic \\
acids \\
\end{tabular} & $\mathrm{Fe}$ & 95 & $\begin{array}{c}\text { Use of weak } \\
\text { acids }\end{array}$ & $\begin{array}{l}\text { Low battery } \\
\text { efficiency }\end{array}$ & \\
\hline $\mathrm{LiFePO}_{4}$ & $\begin{array}{l}\text { Thermal } \\
\text { treatment }\end{array}$ & $\begin{array}{c}\begin{array}{c}\text { Heating at } \\
\text { high } \\
\text { temperatures } \\
\left(400-600^{\circ} \mathrm{C}\right)\end{array} \\
\end{array}$ & $\mathrm{LiFePO}_{4}$ & 97 & $\begin{array}{c}\text { Environmen } \\
\text { tally } \\
\text { friendly }\end{array}$ & $\begin{array}{l}\text { High Energy } \\
\text { demand }\end{array}$ & [206] \\
\hline $\mathrm{LiFePO}_{4}$ & $\begin{array}{c}\text { Thermal } \\
\text { treatment and } \\
\text { acid } \\
\text { dissolution }\end{array}$ & \begin{tabular}{|c|} 
Annealing at \\
$700^{\circ} \mathrm{C}$ \\
Addition of \\
$\mathrm{HCl}$
\end{tabular} & $\begin{array}{c}\mathrm{FePO}_{4} .2 \mathrm{H}_{2} \\
\mathrm{O}\end{array}$ & - & $\begin{array}{l}\text { Green } \\
\text { process }\end{array}$ & $\begin{array}{c}\text { High } \\
\text { temperatures } \\
\text { needed }\end{array}$ & [207] \\
\hline \multirow{2}{*}{$\mathrm{LiFePO}_{4}$} & \multirow{2}{*}{$\begin{array}{l}\text { Solution- } \\
\text { precipitation }\end{array}$} & $\begin{array}{c}\text { Addition of } \\
\mathrm{H}_{2} \mathrm{SO}_{4}\end{array}$ & $\mathrm{FePO}_{4}$ & 98 & \multirow{2}{*}{$\begin{array}{c}\text { Good } \\
\text { electrochem } \\
\text { ical } \\
\text { performance }\end{array}$} & \multirow{2}{*}{$\begin{array}{l}\text { Use of toxic } \\
\text { reagents }\end{array}$} & \multirow{2}{*}{ [208] } \\
\hline & & $\begin{array}{c}\text { Addition of } \\
\mathrm{Na}_{2} \mathrm{CO}_{3} \\
\end{array}$ & $\mathrm{Li}_{2} \mathrm{CO}_{3}$ & 97 & & & \\
\hline \multirow[b]{3}{*}{$\begin{array}{l}\mathrm{LiFePO}_{4} \\
\mathrm{LiMnO}_{2}\end{array}$} & \multirow[b]{3}{*}{$\begin{array}{l}\text { Leaching- } \\
\text { flotation- } \\
\text { precipitation }\end{array}$} & \multirow{3}{*}{$\begin{array}{c}\text { Addition of } \\
\text { HCl; } \\
\text { Addition of } \\
\text { [Hbet][Tf } 2 \mathrm{~N}] \\
\text {, n-butyl } \\
\text { xanthate and } \\
\text { a-Terpineol; } \\
\text { Addition of } \\
\mathrm{KMnO}_{4}\end{array}$} & $\mathrm{Li}$ & 81 & \multirow[b]{3}{*}{$\begin{array}{l}\text { High purity } \\
\text { recovered } \\
\text { metals }\end{array}$} & \multirow[b]{3}{*}{$\begin{array}{l}\text { Low recovery } \\
\text { efficiencies }\end{array}$} & \multirow[b]{3}{*}{ [209] } \\
\hline & & & $\mathrm{Fe}$ & 85 & & & \\
\hline & & & $\mathrm{Mn}$ & 81 & & & \\
\hline \multirow{4}{*}{$\begin{array}{c}\mathrm{Li}\left(\mathrm{Ni}_{1 / 3} \mathrm{Co}_{1 / 3} \mathrm{Mn}_{1 /}\right. \\
\left.{ }_{3}\right) \mathrm{O}_{2}\end{array}$} & \multirow{4}{*}{ Acid leaching } & \multirow{4}{*}{$\begin{array}{l}\text { Addition of } \\
\text { lactic acid }\end{array}$} & $\mathrm{Li}$ & 98 & \multirow{4}{*}{$\begin{array}{c}\text { Environmen } \\
\text { tally } \\
\text { friendly }\end{array}$} & \multirow{4}{*}{$\begin{array}{l}\text { Complex } \\
\text { process }\end{array}$} & \multirow{4}{*}{ [210] } \\
\hline & & & $\mathrm{Ni}$ & 98 & & & \\
\hline & & & Co & 99 & & & \\
\hline & & & $\mathrm{Mn}$ & 98 & & & \\
\hline \multirow{3}{*}{$\begin{array}{c}\mathrm{Li}\left(\mathrm{Ni}_{1 / 3} \mathrm{Co}_{1 / 3} \mathrm{Mn}_{1 /}\right. \\
\text { 3) }_{2}\end{array}$} & \multirow{3}{*}{ Acid leaching } & \multirow{3}{*}{$\begin{array}{l}\text { Addition of } \\
\left(\mathrm{NH}_{4}\right)_{2} \mathrm{SO}_{3}\end{array}$} & $\mathrm{Ni}$ & 95 & \multirow{3}{*}{$\begin{array}{c}\text { Selective } \\
\text { leaching of } \\
\text { different } \\
\text { metals }\end{array}$} & \multirow{3}{*}{$\begin{array}{l}\text { Low Mn } \\
\text { leaching } \\
\text { efficiency }\end{array}$} & \multirow{3}{*}{ [211] } \\
\hline & & & Co & 88 & & & \\
\hline & & & $\mathrm{Li}$ & 97 & & & \\
\hline \multirow{4}{*}{$\begin{array}{c}\mathrm{Li}\left(\mathrm{Ni}_{1 / 3} \mathrm{Co}_{1 / 3} \mathrm{Mn}_{1 /}\right. \\
\text { 3) }_{2}\end{array}$} & \multirow{4}{*}{ Acid leaching } & \multirow{4}{*}{$\begin{array}{l}\text { Addition of } \\
\text { trichloroaceti } \\
\mathrm{c} \text { acid }\end{array}$} & $\mathrm{Ni}$ & 93 & \multirow{4}{*}{$\begin{array}{c}\text { High } \\
\text { selectivity }\end{array}$} & \multirow{4}{*}{$\begin{array}{l}\text { Low Al } \\
\text { leaching } \\
\text { efficiency }\end{array}$} & \multirow{4}{*}{ [212] } \\
\hline & & & Co & 91 & & & \\
\hline & & & $\mathrm{Mn}$ & 89 & & & \\
\hline & & & $\mathrm{Li}$ & 99 & & & \\
\hline \multirow{4}{*}{$\begin{array}{c}\mathrm{Li}\left[\mathrm{Ni}_{1 / 3} \mathrm{Mn}_{1 / 3} \mathrm{Co}_{1 /}\right. \\
\left.{ }_{3}\right] \mathrm{O}_{2}\end{array}$} & \multirow{4}{*}{ Acid leaching } & \multirow{4}{*}{\begin{tabular}{|c|}
$2 \mathrm{M}$ \\
$\mathrm{H} 2 \mathrm{SO} 4,5$ \\
vol $\% \mathrm{H} 2 \mathrm{O} 2$ \\
$60 \mathrm{C}, 300$ \\
rpm, 50 \\
g/500 $\mathrm{mL}$ \\
and $2 \mathrm{~h}$. \\
\end{tabular}} & $\mathrm{Li}$ & 98 & \multirow{4}{*}{$\begin{array}{l}\text { High } \\
\text { recovery } \\
\text { percentage }\end{array}$} & & \\
\hline & & & Co & 98 & & acid use and & [213] \\
\hline & & & $\mathrm{Mn}$ & 98 & & & \\
\hline & & & $\mathrm{Ni}$ & 98 & & & \\
\hline $\begin{array}{c}\mathrm{Li}\left(\mathrm{Ni}_{1 / 3} \mathrm{Co}_{1 / 3} \mathrm{Mn}_{1 /}\right. \\
\left.{ }_{3}\right) \mathrm{O}_{2}\end{array}$ & Acid leaching & $\begin{array}{c}\text { Addition of } \\
\mathrm{H}_{2} \mathrm{SO}_{4}\end{array}$ & $\begin{array}{c}\mathrm{LiNi}_{1 / 3} \mathrm{Co}_{1 /} \\
{ }_{3} \mathrm{Mn}_{1 / 3} \mathrm{O}_{2}\end{array}$ & - & \begin{tabular}{|c} 
Good \\
electrochem \\
ical
\end{tabular} & $\begin{array}{c}\text { Complex } \\
\text { process }\end{array}$ & [214] \\
\hline
\end{tabular}




\begin{tabular}{|c|c|c|c|c|c|c|c|}
\hline & & & & & $\begin{array}{c}\text { performance } \\
\text { of the } \\
\text { recovered } \\
\text { material }\end{array}$ & & \\
\hline $\begin{array}{c}\mathrm{Li}\left(\mathrm{Ni}_{1 / 3} \mathrm{Co}_{1 / 3} \mathrm{Mn}_{1 /}\right. \\
\left.{ }_{3}\right)_{2}\end{array}$ & Acid leaching & $\begin{array}{l}\text { Addition of } \\
\text { nitric acid }\end{array}$ & $\begin{array}{c}\mathrm{LiNi}_{1 / 3} \mathrm{Co}_{1 /} \\
{ }_{3} \mathrm{Mn}_{1 / 3} \mathrm{O}_{2}\end{array}$ & - & $\begin{array}{l}\text { Simple and } \\
\text { cheap } \\
\text { method }\end{array}$ & $\begin{array}{c}\text { Low } \\
\text { performance of } \\
\text { the recovered } \\
\text { materials }\end{array}$ & [215] \\
\hline \multirow{3}{*}{$\begin{array}{c}\mathrm{Li}\left(\mathrm{Ni}_{1 / 3} \mathrm{Co}_{1 / 3} \mathrm{Mn}_{1 /}\right. \\
\left.{ }_{3}\right) \mathrm{O}_{2}\end{array}$} & \multirow{3}{*}{$\begin{array}{l}\text { Microwave } \\
\text { carbothermic } \\
\text { reduction, } \\
\text { acid leaching }\end{array}$} & \multirow{3}{*}{$\begin{array}{c}\text { Microwave } \\
\text { power of } \\
100-700 \mathrm{~W} \\
\text { for } 30 \mathrm{~min} ; \\
\text { addition of } \\
\text { fumaric acid }\end{array}$} & Co & 98 & \multirow{3}{*}{$\begin{array}{l}\text { High } \\
\text { efficiency }\end{array}$} & \multirow{3}{*}{$\begin{array}{l}\text { High energy } \\
\text { consumption }\end{array}$} & \multirow{3}{*}{ [216] } \\
\hline & & & $\mathrm{Ni}$ & 98 & & & \\
\hline & & & $\mathrm{Mn}$ & 96 & & & \\
\hline $\begin{array}{c}\mathrm{LiCo}_{0.415} \mathrm{Mn}_{0.435} \mathrm{~N} \\
\mathrm{i}_{0.15} \mathrm{O}_{2}\end{array}$ & Acid leaching & $\begin{array}{c}3 \mathrm{~mL} 30 \% \\
\mathrm{H}_{2} \mathrm{O}_{2} \text { in } 100 \\
\mathrm{ml}^{\circ} 2 \mathrm{M} \\
\mathrm{HNO}_{3} \\
\text { heated at } 70 \\
{ }^{\circ} \mathrm{C} \\
\end{array}$ & - & - & $\begin{array}{l}\text { synthesise } \\
\text { cathode } \\
\text { material }\end{array}$ & $\begin{array}{c}\text { Very specific } \\
\text { and complicated }\end{array}$ & [13] \\
\hline \multirow{2}{*}{$\begin{array}{c}\mathrm{LiNi}_{0.8} \mathrm{Co}_{0.15} \mathrm{Al}_{0.0} \\
{ }_{5} \mathrm{O}_{2}\end{array}$} & \multirow{2}{*}{ Acid leaching } & \multirow{2}{*}{$\begin{array}{c}\text { Addition of } \\
\mathrm{HCl}\end{array}$} & Co & $\sim 100$ & \multirow{2}{*}{$\begin{array}{l}\text { High } \\
\text { recovery } \\
\text { rates }\end{array}$} & \multirow{2}{*}{$\begin{array}{c}\text { Low purities on } \\
\text { the obtained } \\
\text { metals }\end{array}$} & \multirow{2}{*}{ [217] } \\
\hline & & & $\mathrm{Ni}$ & 99 & & & \\
\hline \multirow{4}{*}{$\begin{array}{c}\mathrm{Li}\left(\mathrm{Ni}_{1 / 3} \mathrm{Co}_{1 / 3} \mathrm{Mn}_{1 /}\right. \\
\text { 3) } \mathrm{O}_{2} ; \mathrm{LiCoO}_{2} \\
\mathrm{LiMnO}_{2}\end{array}$} & \multirow{4}{*}{$\begin{array}{c}\text { Selective } \\
\text { precipitation }\end{array}$} & $\begin{array}{l}\text { Addition of } \\
\text { DMG } \\
\text { reagent } \\
\end{array}$ & $\mathrm{Ni}$ & 98.7 & \multirow{4}{*}{$\begin{array}{l}\text { High } \\
\text { selectivity }\end{array}$} & \multirow{4}{*}{$\begin{array}{l}\text { Use of toxic } \\
\text { reagents }\end{array}$} & \multirow{4}{*}{ [218] } \\
\hline & & $\begin{array}{r}\text { Addition of } \\
\text { Co-D2EHPA }\end{array}$ & $\mathrm{Mn}$ & 97.1 & & & \\
\hline & & $\begin{array}{c}\text { Addition of } \\
{\left[\left(\mathrm{NH}_{4}\right)_{2} \mathrm{C}_{2} \mathrm{O}_{4}\right.} \\
]\end{array}$ & $\begin{array}{c}\mathrm{CoC}_{2} \mathrm{O}_{4} \cdot 2 \mathrm{H} \\
{ }_{2} \mathrm{O}\end{array}$ & 98.2 & & & \\
\hline & & $\begin{array}{c}\text { Addition of } \\
\mathrm{Na}_{2} \mathrm{CO}_{3} \text { at } \\
95^{\circ} \mathrm{C} \\
\end{array}$ & $\mathrm{Li}_{2} \mathrm{CO}_{3}$ & 81.0 & & & \\
\hline \multirow{2}{*}{$\begin{array}{c}\mathrm{Li}\left(\mathrm{Ni}_{1 / 3} \mathrm{Co}_{1 / 3} \mathrm{Mn}_{1 /}\right. \\
\left.{ }_{3}\right) \mathrm{O}_{2}\end{array}$} & \multirow{2}{*}{$\begin{array}{l}\text { Hydrometallu } \\
\text { rgical } \\
\text { leaching }\end{array}$} & \multirow[t]{2}{*}{$\begin{array}{l}\text { Addition of } \\
\text { citric acid }\end{array}$} & $\mathrm{Li}$ & 93 & \multirow{2}{*}{$\begin{array}{c}\text { Environmen } \\
\text { tally } \\
\text { friendly }\end{array}$} & \multirow{2}{*}{$\begin{array}{c}\text { Lower } \\
\text { electrochemical } \\
\text { performance }\end{array}$} & \multirow[t]{2}{*}{ [219] } \\
\hline & & & Co & 99 & & & \\
\hline $\begin{array}{c}\mathrm{Li}\left(\mathrm{Ni}_{1 / 3} \mathrm{Co}_{1 / 3} \mathrm{Mn}_{1 /}\right. \\
\text { 3) } \mathrm{O}_{2}\end{array}$ & $\begin{array}{c}\text { Solvent } \\
\text { dissolution; } \\
\text { heat treatment }\end{array}$ & $\begin{array}{l}\text { Addition of } \\
\mathrm{NMP} ; \\
\text { calcination } \\
\text { at } 800^{\circ} \mathrm{C} \\
\end{array}$ & $\begin{array}{c}\mathrm{LiNi}_{1 / 3} \mathrm{Co}_{1 /} \\
{ }_{3} \mathrm{Mn}_{1 / 3} \mathrm{O}_{2}\end{array}$ & - & $\begin{array}{l}\text { High } \\
\text { discharge } \\
\text { capacities }\end{array}$ & $\begin{array}{c}\text { High } \\
\text { temperatures } \\
\text { needed }\end{array}$ & {$[220]$} \\
\hline \multirow{3}{*}{$\begin{array}{c}\mathrm{Li}\left(\mathrm{Ni}_{1 / 3} \mathrm{Co}_{1 / 3} \mathrm{Mn}_{1 /}\right. \\
\left.{ }_{3}\right) \mathrm{O}_{2}\end{array}$} & \multirow{3}{*}{$\begin{array}{l}\text { Solvent } \\
\text { extraction }\end{array}$} & \multirow{3}{*}{$\begin{array}{c}\text { Addition of } \\
\text { DH2EHPA } \\
\text { and kerosene }\end{array}$} & $\mathrm{Mn}$ & $\sim 100$ & \multirow{3}{*}{$\begin{array}{l}\text { Low } \\
\text { temperature } \\
\text { s required }\end{array}$} & \multirow{3}{*}{$\begin{array}{l}\text { Complex } \\
\text { process }\end{array}$} & \multirow{3}{*}{ [221] } \\
\hline & & & $\mathrm{Co}$ & 99 & & & \\
\hline & & & $\mathrm{Ni}$ & 85 & & & \\
\hline \multirow{4}{*}{$\begin{array}{c}\mathrm{Li}\left(\mathrm{Ni}_{1 / 3} \mathrm{Co}_{1 / 3} \mathrm{Mn}_{1 /}\right. \\
\left.{ }_{3}\right) \mathrm{O}_{2}\end{array}$} & \multirow{4}{*}{$\begin{array}{l}\text { Reduction } \\
\text { roasting }\end{array}$} & \multirow{4}{*}{$\begin{array}{c}\text { Roasting at } \\
650^{\circ} \mathrm{C} \text { for } \\
3 \mathrm{~h} \text {; Leaching } \\
\text { with } \mathrm{H}_{2} \mathrm{SO}_{4}\end{array}$} & $\mathrm{Ni}$ & 99 & \multirow{4}{*}{$\begin{array}{l}\text { High } \\
\text { recovery } \\
\text { efficiencies }\end{array}$} & \multirow{4}{*}{$\begin{array}{l}\text { Requires high } \\
\text { temperatures }\end{array}$} & \\
\hline & & & $\mathrm{Co}$ & 99 & & & [222] \\
\hline & & & $\mathrm{Mn}$ & 99 & & & \\
\hline & & & $\mathrm{Li}$ & 85 & & & \\
\hline
\end{tabular}




\begin{tabular}{|c|c|c|c|c|c|c|c|}
\hline$\alpha-\mathrm{MnO}_{2}$ & $\begin{array}{l}\text { Thermal } \\
\text { regeneration }\end{array}$ & $\begin{array}{l}\text { Addition of } \\
\text { dimethyl } \\
\text { carbonate, } \\
\text { heating at } \\
300^{\circ} \mathrm{C}\end{array}$ & $\alpha-\mathrm{MnO}_{2}$ & - & $\begin{array}{c}\text { Allows } \\
\text { several } \\
\text { regeneration } \\
\mathrm{s}\end{array}$ & $\begin{array}{c}\text { High } \\
\text { temperatures } \\
\text { needed }\end{array}$ & [125] \\
\hline \multirow{4}{*}{$\begin{array}{l}\text { Mixed cathode } \\
\text { materials }\end{array}$} & \multirow{4}{*}{ Acid leaching } & \multirow{4}{*}{$\begin{array}{c}4 \mathrm{M} \text { sulfuric } \\
\text { acid and } \\
30 \mathrm{wt} \% \\
\text { hydrogen } \\
\text { peroxide }(2- \\
3 \text { hours at } \\
\left.70-80^{\circ} \mathrm{C}\right) \\
\end{array}$} & $\mathrm{Ni}$ & 100 & \multirow{4}{*}{$\begin{array}{l}\text { unspecified } \\
\text { cathode } \\
\text { material, } \\
\text { low } \\
\text { temperature }\end{array}$} & \multirow{4}{*}{$\begin{array}{l}\text { just focus on } \\
\text { recycling the } \\
\text { active material, } \\
\text { acid use }\end{array}$} & \multirow{4}{*}{ [168] } \\
\hline & & & $\mathrm{Mn}$ & 100 & & & \\
\hline & & & $\mathrm{Co}$ & 100 & & & \\
\hline & & & $\mathrm{Li}$ & 80 & & & \\
\hline \multirow{3}{*}{$\begin{array}{l}\text { Mixed cathode } \\
\text { materials }\end{array}$} & \multirow{3}{*}{ Acid leaching } & \multirow{3}{*}{$\begin{array}{l}\text { Addition of } \\
\left(\mathrm{NH}_{4}\right)_{2} \mathrm{SO}_{3} \\
\left(\mathrm{NH}_{4}\right)_{2} \mathrm{CO}_{3}\end{array}$} & $\mathrm{Ni}$ & 25 & \multirow{3}{*}{$\begin{array}{l}\text { High } \mathrm{Cu} \\
\text { leaching } \\
\text { efficiency }\end{array}$} & \multirow{3}{*}{$\begin{array}{l}\text { Low efficiency } \\
\text { for other metals }\end{array}$} & \multirow{3}{*}{ [223] } \\
\hline & & & $\mathrm{Co}$ & 80 & & & \\
\hline & & & $\mathrm{Cu}$ & 100 & & & \\
\hline \multirow{6}{*}{$\begin{array}{l}\text { Mixed electrode } \\
\text { materials }\end{array}$} & \multirow{6}{*}{ Acid leaching } & \multirow{6}{*}{$\begin{array}{l}\text { Addition of } \\
\text { acids } \\
\text { produced by } \\
\text { Aspergillus } \\
\text { niger }\end{array}$} & $\mathrm{Li}$ & $\sim 100$ & \multirow{6}{*}{$\begin{array}{c}\text { Environmen } \\
\text { tally } \\
\text { friendly }\end{array}$} & \multirow{6}{*}{$\begin{array}{l}\text { Low leaching } \\
\text { efficiencies for } \\
\text { some metals }\end{array}$} & \multirow{6}{*}{ [224] } \\
\hline & & & $\mathrm{Mn}$ & 77 & & & \\
\hline & & & $\mathrm{Ni}$ & 54 & & & \\
\hline & & & $\mathrm{Co}$ & 64 & & & \\
\hline & & & $\mathrm{Al}$ & 75 & & & \\
\hline & & & $\mathrm{Cu}$ & $\sim 100$ & & & \\
\hline \multirow{5}{*}{$\begin{array}{l}\text { Mixed electrode } \\
\text { materials }\end{array}$} & \multirow{5}{*}{$\begin{array}{l}\text { Leaching/ } \\
\text { precipitation } \\
\text { with } \mathrm{HCl}\end{array}$} & $\begin{array}{c}\text { Addition of } \\
\text { hypochlorite }\end{array}$ & Mn & $>99$ & \multirow{5}{*}{$\begin{array}{l}\text { High } \\
\text { selectivity }\end{array}$} & \multirow{5}{*}{$\begin{array}{l}\text { Different } \\
\text { optimal } \\
\text { conditions for } \\
\text { each metal }\end{array}$} & \multirow{5}{*}{ [225] } \\
\hline & & $\begin{array}{c}\text { Addition of } \\
\mathrm{NaOH} \text { at } \mathrm{pH} \\
4.5\end{array}$ & $\mathrm{Al}(\mathrm{OH})_{3}$ & $<1$ & & & \\
\hline & & $\begin{array}{c}\text { Addition of } \\
\mathrm{NaOH} \text { at } \mathrm{pH} \\
5.5 \\
\end{array}$ & $\mathrm{Cu}(\mathrm{OH})_{3}$ & $<1$ & & & \\
\hline & & $\begin{array}{c}\text { Addition of } \\
\mathrm{Na}_{2} \mathrm{CO}_{3} \\
\end{array}$ & $\mathrm{CoCO}_{3}$ & $>99$ & & & \\
\hline & & $\begin{array}{l}\text { Addition of } \\
\mathrm{Na}_{2} \mathrm{CO}_{3}\end{array}$ & $\mathrm{Li}_{2} \mathrm{CO}_{3}$ & $>99$ & & & \\
\hline $\begin{array}{l}\text { Mixed electrode } \\
\text { materials }\end{array}$ & $\begin{array}{l}\text { Hydrometallu } \\
\text { rgical }\end{array}$ & $\begin{array}{c}\text { Leaching } \\
\text { with } \mathrm{NaOH} \\
\text { and } \mathrm{H}_{2} \mathrm{SO}_{4} \text {; } \\
\text { Precipitation } \\
\text { with } \\
\left(\mathrm{NH}_{4}\right)_{2} \mathrm{C}_{2} \mathrm{O}_{4} \\
\text { solution }\end{array}$ & $\mathrm{CoC}_{2} \mathrm{O}_{4}$ & - & $\begin{array}{l}\text { Simple } \\
\text { process }\end{array}$ & $\begin{array}{c}\text { Energy } \\
\text { demanding }\end{array}$ & [226] \\
\hline \multirow[b]{2}{*}{$\begin{array}{l}\text { Mixed electrode } \\
\text { materials }\end{array}$} & \multirow[b]{2}{*}{$\begin{array}{l}\text { Grinding } \\
\text { flotation }\end{array}$} & \multirow{2}{*}{$\begin{array}{c}\text { Using of } \\
\text { Hardgrove } \\
\text { and flotation } \\
\text { apparatus }\end{array}$} & $\mathrm{LiCoO}_{2}$ & 49 & \multirow[b]{2}{*}{$\begin{array}{l}\text { No use of } \\
\text { toxic } \\
\text { reagents }\end{array}$} & \multirow[b]{2}{*}{$\begin{array}{l}\text { Low recovery } \\
\text { efficiencies }\end{array}$} & \multirow[b]{2}{*}{ [227] } \\
\hline & & & Graphite & 74 & & & \\
\hline \multirow{3}{*}{$\begin{array}{c}\text { Mixed electrode } \\
\text { materials }\end{array}$} & \multirow{3}{*}{$\begin{array}{c}\text { Oxygen-free } \\
\text { roasting, wet } \\
\text { magnetic } \\
\text { separation }\end{array}$} & \multirow{3}{*}{$\begin{array}{l}30 \text { minutes } \\
\text { at } 1000^{\circ} \mathrm{C}\end{array}$} & Co & 95 & \multirow{3}{*}{$\begin{array}{l}\text { No need for } \\
\text { chemical } \\
\text { solutions }\end{array}$} & & \\
\hline & & & $\mathrm{Li}$ & 98 & & temperatures & [208] \\
\hline & & & Graphite & 91 & & needed & \\
\hline
\end{tabular}




\begin{tabular}{|c|c|c|c|c|c|c|c|}
\hline \multirow{5}{*}{$\begin{array}{l}\text { Mixed spent } \\
\text { batteries }\end{array}$} & \multirow{5}{*}{ Acid leaching } & \multirow{5}{*}{$\begin{array}{c}\text { Addition of } \\
\mathrm{H}_{2} \mathrm{SO}_{4}\end{array}$} & $\mathrm{Mn}$ & 65 & \multirow{5}{*}{$\begin{array}{l}\text { Separation } \\
\text { of various } \\
\text { metals with } \\
\text { one process }\end{array}$} & \multirow{5}{*}{$\begin{array}{l}\text { Low recovery } \\
\text { efficiencies for } \\
\mathrm{Mn} \text { and } \mathrm{Ni}\end{array}$} & \multirow{5}{*}{ [228] } \\
\hline & & & $\mathrm{Cd}$ & 99 & & & \\
\hline & & & $\mathrm{Zn}$ & 100 & & & \\
\hline & & & $\mathrm{Co}$ & 74 & & & \\
\hline & & & $\mathrm{Ni}$ & 68 & & & \\
\hline
\end{tabular}




\subsubsection{Chemical methods: leaching}

Hydrometallurgical processes are and have been intensely investigated. $\mathrm{Ni}, \mathrm{Co}, \mathrm{Li}$ and Mn can be recovered from disposed of LIBs in a sulfuric acid leach mixture [229]. The selective precipitation of the metals using different agents, dimethylglyoxime reagent for $\mathrm{Ni}$, di-(2-ethylhexly) phosphoric acid (D2EHPA) for Mn, ammonium oxalate solution for Co and saturated sodium carbonate solution for Li. This allowed high recovery efficiencies ( $98.7 \%$ for $\mathrm{Ni}, 98.2 \%$ for $\mathrm{Co}, 97.1 \%$ for $\mathrm{Mn}$ and $81 \%$ for $\mathrm{Li}$ ) [218].

Hydrometallurgy is also reported in the recovery of cobalt in spent LIBS (LIBs) through sulphuric acid-hydrogen peroxide system, producing cobalt up with purity up to $99.50 \%$, determined by 0.5 mol. $\mathrm{L}^{-1}$ oxalic acid solution [177]. The addition of a microwave irradiation step to the process proved to increase the recovery efficiency [216].

An efficient hydrometallurgical recycling process including pre-treatment has been developed attending to the used electrodes, showing the possibility to recover, in a single process, high-grade graphite, cathode metals and lithium carbonate. The leaching efficiencies for metals ( $\mathrm{Co}, \mathrm{Ni}, \mathrm{Cu}$ and $\mathrm{Li}$ ) are in the range of 98.6-99.9\% under the reported optimum conditions: $80^{\circ} \mathrm{C}, 50 \mathrm{~g} . \mathrm{L}^{-1}$ of hydrogen peroxide, $2 \mathrm{~mol} . \mathrm{L}^{-1}$ of sulphuric acid or 4 mol. $\mathrm{L}^{-1}$ of hydrochloric acid in $2 \mathrm{~h}$ [230]. The introduction of a mechanochemical pretreatment before the leaching steps can increase these efficiencies further, to near $100 \%$ [188].

A study of the optimal conditions in $\mathrm{Li}$ and Co recovery from cathode active materials was performed. The use of oxalate as a leaching agent and precipitant element proved to be effective, especially at high concentrations and higher temperatures [201]. Hydrochloric acid [172, 173, 217, 225], lactic acid [210], citric acid (Figure 18) [170, $185,186,219]$, nitric acid [58, 184], sulfuric acid [178-180, 189, 228], oxalic acid [175] and Cyanex 272 [182, 183, 231] are some of the acids that can be used effectively to extract $\mathrm{Li}, \mathrm{Co}$ or Mn at high efficiency and low energy consumption, due to the absence of thermal processes. Mild organic acids, such as iminodiacetic and maleic acid, are also environmentally friendly alternatives, although their efficiencies are lower than the stronger acids reported before [187].

The acids used in the leaching process can also be produced biological activity with satisfactory results [224]. Combining oxalic acid and malic acid allows the production of cobalt oxalate, which can be used as a precursor for the synthesis of $\mathrm{LiCoO}_{2}$, without the need to use Hydrogen peroxide as reducing agent [181]. The association of glucose with phosphoric acid to reduce cobalt (III) into cobalt (II) was reported. At the end of the 
leaching process oxalic acid was added, in order to precipitate the Co with an efficiency of $98 \%$, as Co-oxalate [176].

Fenton reagent can be successfully applied in the separation of $\mathrm{LiCoO}_{2}$ and graphite using assisted flotation methods [202] The ratios of $\mathrm{Fe}^{2+} / \mathrm{H}_{2} \mathrm{O}_{2}$ and that of liquid/solids at room temperature have investigated. The optimum conditions are such that the $\mathrm{Fe}^{2+} / \mathrm{H}_{2} \mathrm{O}_{2}$ ratio is $1: 120$, and the liquid-solid ratio is $75: 1$ so that most of the layer coating electrode materials surface based on organic materials can be removed [202].

A hydrothermal method with immersion in $\mathrm{LiOH}$ aqueous solution allows the simultaneous regeneration and partial separation of $\mathrm{LiCoO}_{2}$ from spent electrodes [192]. The use of supercritical fluids proved to significantly reduce the leaching time and the amount of $\mathrm{H}_{2} \mathrm{O}_{2}$ needed for the effective recovery of Cobalt [195]. Just like $\mathrm{LiCoO}_{2}$, $\mathrm{LiFePO}_{4}$ can also be successfully leached using different agents such as phosphoric acid [203]. The leaching methods for the recovery of $\mathrm{Li}\left(\mathrm{Ni}_{1 / 3} \mathrm{Co}_{1 / 3} \mathrm{Mn}_{1 / 3}\right) \mathrm{O}_{2}$ active material involve the use of nitric acid [215]. Work on this active material showed that the optimum conditions by leaching methods are treatment with $2 \mathrm{M} \mathrm{H}_{2} \mathrm{SO}_{4}, 5$ vol $\% \mathrm{H}_{2} \mathrm{O}_{2}, 60{ }^{\circ} \mathrm{C}, 300$ $\mathrm{rpm}, 50 \mathrm{~g} / 500 \mathrm{~mL}$, reaching leaching efficiencies of valuable metals (Co, $\mathrm{Li}, \mathrm{Ni}, \mathrm{Mn}$ ) over $98 \%$, with concentrations of Co 10.4 g.L ${ }^{-1}$, Li 12.3 g.L ${ }^{-1}$, Ni 16.1 g.L L $^{-1}$, Mn 14.5 g. $\mathrm{L}^{-1}$, and $\mathrm{Al} 0.3 \mathrm{~g} . \mathrm{L}^{-1}$, respectively [213]. Also, for this active material, a new process for the synthesis of $\mathrm{LiNi}_{1 / 3} \mathrm{Co}_{1 / 3} \mathrm{Mn}_{1 / 3} \mathrm{O}_{2}$ from valuable recycled metals of waste LIBS by citric acid as both a leaching and chelating agent was developed. NMP was used to separate the active material from the aluminium foil. Then the leaching process was carried out with $0.5-2.0$ mol. $\mathrm{L}^{-1}$ concentrations of citric acid, also varying the $\mathrm{H}_{2} \mathrm{O}_{2}$ concentration (0-25 Vol.\%). Some parameters, including time and temperature, were variated to optimize the process [232].

Electrodeposition with $99 \% \mathrm{Al}$ working electrodes and an area of $0.40 \mathrm{~cm}^{2}$ shows promising results under specific conditions $(\mathrm{pH}=5.4$ and voltage applied of $-1 \mathrm{~V})$, with efficiencies up to $96 \%$ for metals [196]. Methods of oxygen-free roasting and wet magnetic separation were developed to recycle $\mathrm{Li}, \mathrm{Co}$ and graphite. The main advantage of these methods is that they prevent the addition of chemical solutions to the process, which means that there are fewer costs in the treatment of waste solutions, making these techniques more environmentally friendly alternatives [208].

$\mathrm{Xu}$ et al. developed a method to recover $\mathrm{LiCoO}_{2}$ from spent LIBs using DMF and a thermal treatment. This method has a low cost, and the recycled $\mathrm{LiCoO}_{2}$ can be 
successfully used in $\mathrm{Ni} / \mathrm{Co}$ batteries as negative materials (cathode electrode) with high efficiencies [198].

Another approach was developed for spent $\mathrm{LiCoO}_{2}$ batteries which were dismantled, separated and recycled without secondary pollution, avoiding the production of residues as acids or other subproducts from recovery processes [233]. The electrochemical process of Etoile-Rebatt aqueous solution technology enabled the recovery and renovation of $\mathrm{LiCoO}_{2}$ exhibiting an initial discharge capacity of $134.8 \mathrm{mAh} \cdot \mathrm{g}^{-1}$, and a discharge capacity retention of $95.9 \%$ after 50 cycles [234]. Wet and dry crushing methods have been adopted to experiments on recycling of $\mathrm{LiCoO}_{2}$ material [133]. It was demonstrated that the recycling of $\mathrm{LiCoO}_{2}$ cathode material can yield $\mathrm{Co}(\mathrm{OH})_{2}$ and $\mathrm{Co}_{3} \mathrm{O}_{4}$ films for supercapacitors applications [235] where $10.0 \mathrm{~g}$ of the cathode material were dissolved in $1.0 \mathrm{~L}$ of $\mathrm{HNO}_{3} 3.0 \mathrm{~mol} . \mathrm{L}^{-1}$ and stirred for $2 \mathrm{~h}$ at $80^{\circ} \mathrm{C}[236]$ and alkaline medium $(\mathrm{KOH}$ 6 mol.L $\left.\mathrm{L}^{-1}\right)$ [237].

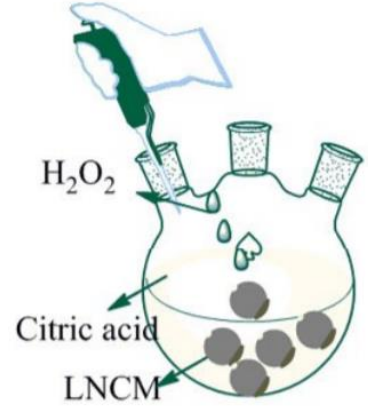

Before Leaching

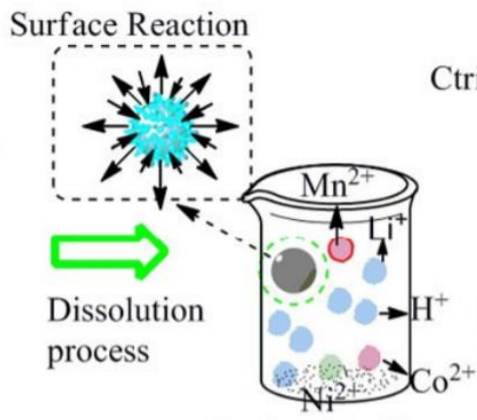

During leaching
Ctric acid metal complexation

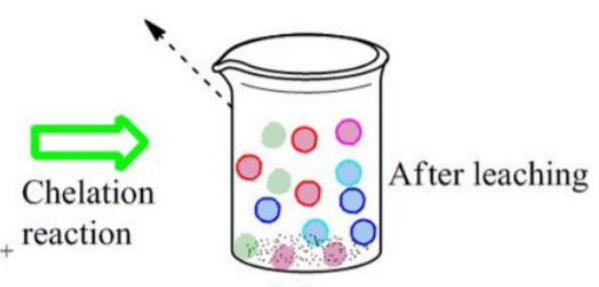

Filtration

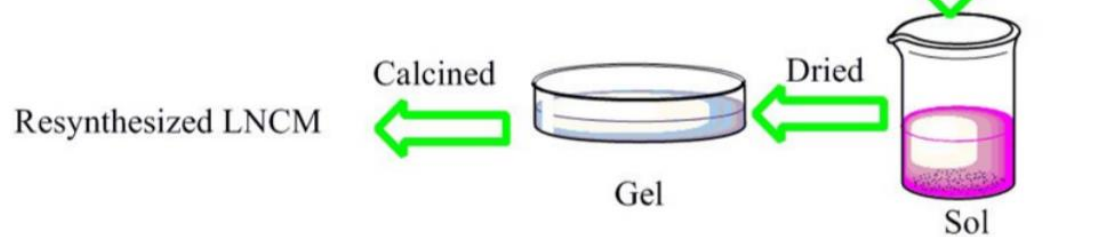

Figure 18 - Schematic diagram of the proposed process of $\mathrm{LiNi}_{1 / 3} \mathrm{Co}_{1 / 3} \mathrm{Mn}_{1 / 3} \mathrm{O}_{2}$ active material resynthesis [232].

The preparation of a crystalline $\mathrm{FePO}_{4} \cdot 2 \mathrm{H}_{2} \mathrm{O}$ phase with lithium sources from spent batteries can be used for the optimised synthesis (heat treatment with best results at 700 ${ }^{\circ} \mathrm{C}$ ) of carbon-coated $\mathrm{LiFePO}_{4}$ regenerated active materials. It was found that the prepared powder presents satisfactory electrochemical performances, highlighting the discharge capacity of $140 \mathrm{mAh} \cdot \mathrm{g}^{-1}$ at $1 \mathrm{C}$, and high capacity retention (99\%) [207]. Simple thermal processes with high-efficiency rates can recover LiFePO4 cathode materials. However, the high temperatures needed to decompose the binders make this process energy costly 
[206]. An optimised and simple technique involving dissolution and precipitation with PEG-6000 surfactant at $\mathrm{pH}$ 2, for recovery and regeneration of $\mathrm{LiFePO}_{4}$ cathodes was studied, with a focus on the reducing of the cost and lowering the resulting material waste. The regenerated carbon-coated $\mathrm{LiFePO}_{4}$ active material was then synthesised by carbon thermal reduction, ultimately leading to an excellent electrochemical performance on battery tests, very similar to the conventional ones $\left(120.4 \mathrm{mAh} . \mathrm{g}^{-1}\right.$ for the recovered cathodes and $121.5 \mathrm{mAh} . \mathrm{g}^{-1}$ for a commercial one, at 1C rate) [208]. Weak acids can be used as a greener alternative to the leaching process, despite the lower efficiencies achieved [205].

Different separation and heat treatment methods for the recovery and regeneration of $\mathrm{Li}\left(\mathrm{Ni}_{1 / 3} \mathrm{Co}_{1 / 3} \mathrm{Mn}_{1 / 3}\right) \mathrm{O}_{2}$ active material from electrode scraps were investigated, showing potential for satisfactory electrochemical battery performance. Some authors [238] resynthesized $\mathrm{Li}\left(\mathrm{Ni}_{1 / 3} \mathrm{Co}_{1 / 3} \mathrm{Mn}_{1 / 3}\right) \mathrm{O}_{2}$ after recovering the materials. High recovery efficiency (>99\% for all the metals) was achieved, showing that their recycling process is practical and commercially viable [238]. The solvent dissolution in NMP and calcination at $800^{\circ} \mathrm{C}$ presented the highest reversible discharge capacity, while the direct calcination at $600^{\circ} \mathrm{C}$ showed the best cycling performance [220]. Solvent extraction methods using D2EHPA and kerosene [221] are effective processes to recover metals from battery scraps. Weng et al. developed a method to regenerate $\mathrm{Li}\left(\mathrm{Ni}_{1 / 3} \mathrm{Co}_{1 / 3} \mathrm{Mn}_{1 / 3}\right) \mathrm{O}_{2}$ with pretreatment, leaching, purification and controlled crystallization-solid state synthesis. This process allows the efficient removal of manganese, maintaining only a small amount in the structure of the produced $\mathrm{Li}\left(\mathrm{Ni}_{1 / 3} \mathrm{Co}_{1 / 3} \mathrm{Mn}_{1 / 3}\right) \mathrm{O}_{2}$. The traces of manganese proved to be beneficial to the cycling performance of recycled cathodes [214]. A three-step process was developed to recover $\mathrm{Li}, \mathrm{Fe}$ and $\mathrm{Mn}$ at high efficiencies, from spent mixed $\mathrm{LiFePO}_{4}$ and $\mathrm{LiMnO}_{2}$ cathodes. The steps included leaching with $\mathrm{HCl}$ and $\mathrm{H}_{2} \mathrm{O}_{2}$, flotation with the addition of betainium bis(trifluoromethylsulfonyl) imide ([Hbet $\left.]\left[\mathrm{Tf}_{2} \mathrm{~N}\right]\right)$ ionic liquid, $\mathrm{n}$-butyl xanthate and $\alpha$-Terpineol, and finally precipitation with $\mathrm{KMnO}_{4}$ and $\mathrm{Na}_{3} \mathrm{PO}_{4}$. This process presents both economic and environmental benefits due to its high efficiency (80.93\% for $\mathrm{Li}, 85.40 \%$ for $\mathrm{Fe}$ and $81.02 \%$ for $\mathrm{Mn}$ ), and capability to extract several metals at the same time [209]. A combined process with several steps was also studied. The steps included alkali leaching, reduction roasting, carbonated water leaching and sulfuric acid leaching. This method can recover more than $99 \%$ of the $\mathrm{Co}, \mathrm{Ni}$ and $\mathrm{Mn}$ content, and also $85.7 \%$ of the lithium from the spent LIB [222]. 
The use of ammonia-based compounds, such as ammonium carbonate and ammonium sulphite as leaching agents instead of acid proved to be effective, with good efficiencies for $\mathrm{Ni}, \mathrm{Co}$ and $\mathrm{Li}$, of more than $98 \%[211,223]$. The effect of high temperatures under Argon atmosphere was studied, and proved to significantly increase the recovery efficiency of the metals [197].

Biodegradable trichloroacetic acid was used to dissolve LIB scraps with high leaching rates for $\mathrm{Ni}, \mathrm{Co}, \mathrm{Mn}$ and $\mathrm{Li}$, and low $\mathrm{Al}$ leaching (7\%) [212]. Bertuol et al. studied the efficiency of the spouted bed elutriation technique, in the separation of the spent LIB materials, were particles of different sizes, shapes and densities are separated by a stream of a fluid in a given direction. By variating the airflow velocity in the equipment, the separation of different types of material (metals, polymers and active electrode materials) was achieved easily and inexpensively [199].

A method of recycling metals from a synthetic LIB waste aqueous solution using phosphonate organic linkers was studied. The linkers act as precipitating agents that react with metals, forming materials with potential application as coordinated polymers. Efficient selective precipitation of Manganese and Cobalt was achieved [239]. The use of $\mathrm{Na}_{2} \mathrm{CO}_{3}$ as precipitating agent at the first step to obtain $\mathrm{Li}_{2} \mathrm{CO}_{3}$, followed by a second precipitation with $\mathrm{Na}_{3} \mathrm{PO}_{4}$ proved to be effective in the recovery of $\mathrm{Li}_{3} \mathrm{PO}_{4}$, with an efficiency rate of $92 \%$ [240].

A green process with prospective environmental and economic significance has been experimentally and theoretically established for the sustainable recovery of metals from spent LIBs. Three leaching systems were explored for the application of different biomass as reducing agents. The powders of waste cathode materials were obtained from a pretreatment operation. Then, waste cathode materials were dissolved in citric acid $\left(\mathrm{C}_{6} \mathrm{H}_{8} \mathrm{O}_{7}\right.$, $\mathrm{H}_{3} \mathrm{Cit}$ ) together with different reducing agents (Tea Waste, Phytolacca Americana branches and hydrogen peroxide). Finally, Co and Li-ions dissolved in the lixivium were treated with oxalic and phosphoric acid solutions to recover $\mathrm{Co}$ and $\mathrm{Li}$. $\mathrm{H}_{3} \mathrm{Cit}$ (citric acid) \& tea waste and $\mathrm{H}_{3}$ Cit \& $\mathrm{H}_{2} \mathrm{O}_{2}$ systems revealed similar leaching abilities (96\% Co and 98\% $\mathrm{Li} ; 98 \% \mathrm{Co}$ and $99 \% \mathrm{Li}$, respectively), and the recycled citric acid, which is recovered using stronger acids $\left(\mathrm{H}_{2} \mathrm{C}_{2} \mathrm{O}_{4}\right.$ and $\left.\mathrm{H}_{3} \mathrm{PO}_{4}\right)$, demonstrates similar leaching capability as fresh acid according to circulatory leaching experiments [241]. Citric fruit wastes can be used to recover spent LIBs with high recovery efficiencies in a green process that involves drying, milling, acid leaching and filtration [204]. 
$\mathrm{LiCoO}_{2}$ from spent LIB cathodes can also be recovered and successfully used as anode material for $\mathrm{Ni} / \mathrm{Co}$ power batteries. These batteries use $\mathrm{Ni}(\mathrm{OH})_{2}$ as cathode material and Co-based materials as anode, with $\mathrm{KOH}$ aqueous solution as electrolyte [242].

Recently, an innovative approach to recover $\mathrm{LiFePO}_{4}$ batteries was reported. $0.20 \mathrm{M}$ $\left[\mathrm{Fe}(\mathrm{CN})_{6}\right]^{3-}$ solution enabled the selective removal of lithium with efficiencies up to $99.8 \%$ at room temperature [243].

\subsubsection{Physical methods}

Physical methods avoid the use of harmful reagents, including concentrated acids and bases. Grinding flotation is a separation process based on wettability differences between the electrode materials, such as $\mathrm{LiCoO}_{2}$ and graphite, which makes some materials to float while others sink. However, the efficiency of this method is somewhat low ( $49 \%$ for $\mathrm{LiCoO}_{2}$ and $74 \%$ for graphite), and it needs further improvement [227]. Zhang et al. studied the use of crushing and separating methods in LIB recycling process. They found that spent LIBs display excellent selective crushing properties, which allowed them to separate different materials based on particle size. By using mineral processing techniques, it was possible to create a systematic procedure for recycling these materials [200].

Figure 19 represents a novel mechanochemical technique based on co-grinding and water leaching to yield $\mathrm{LiCl}$ and $\mathrm{CoFe}_{4} \mathrm{O}_{6}$. This method, which can simultaneously recycle battery $\mathrm{LiCoO}_{2}$ and PVC, is very interesting for the industry because it can be scaled up, with good economic feasibility and financial profit (estimated as \$1.07 of profit from the recycling of $1 \mathrm{~kg}$ of wasted LIBS), derived from the recycling and recovery of lithium. [193]. $\mathrm{LiCoO}_{2}$ electrodes from wasted LIBS can be regenerated, using ultrasonic irradiation for 6, 9 and 12 hours. The authors claim that the renovated batteries can offer excellent charge and discharge performance, with an associated value of $99 \%$ of charge efficiency, comparable to the commercial batteries [194]. Vacuum-assisted heat-treating followed by a solid-state reaction at high temperatures also showed some potential, despite the lower discharge capacities obtained [191].

Cathode materials from spent $\mathrm{LiFePO}_{4}$ batteries have also been directly regenerated by a green method at high temperatures. This method avoids the use of acid leaching, using $\mathrm{Li}_{2} \mathrm{CO}_{3}$ in the regeneration process. A temperature range from 600 to $800{ }^{\circ} \mathrm{C}$ was studied. Cathodes recovered at $650{ }^{\circ} \mathrm{C}$ presented the best physical, chemical and electrochemical performance [244]. Also for this active material, a green recycling process and a small 
scale model line was developed to recycle cathode powders after heat-treatment at high temperatures, especially at $650{ }^{\circ} \mathrm{C}$, cathode powders are effectively repaired and could be reused in Li-ion batteries [245].

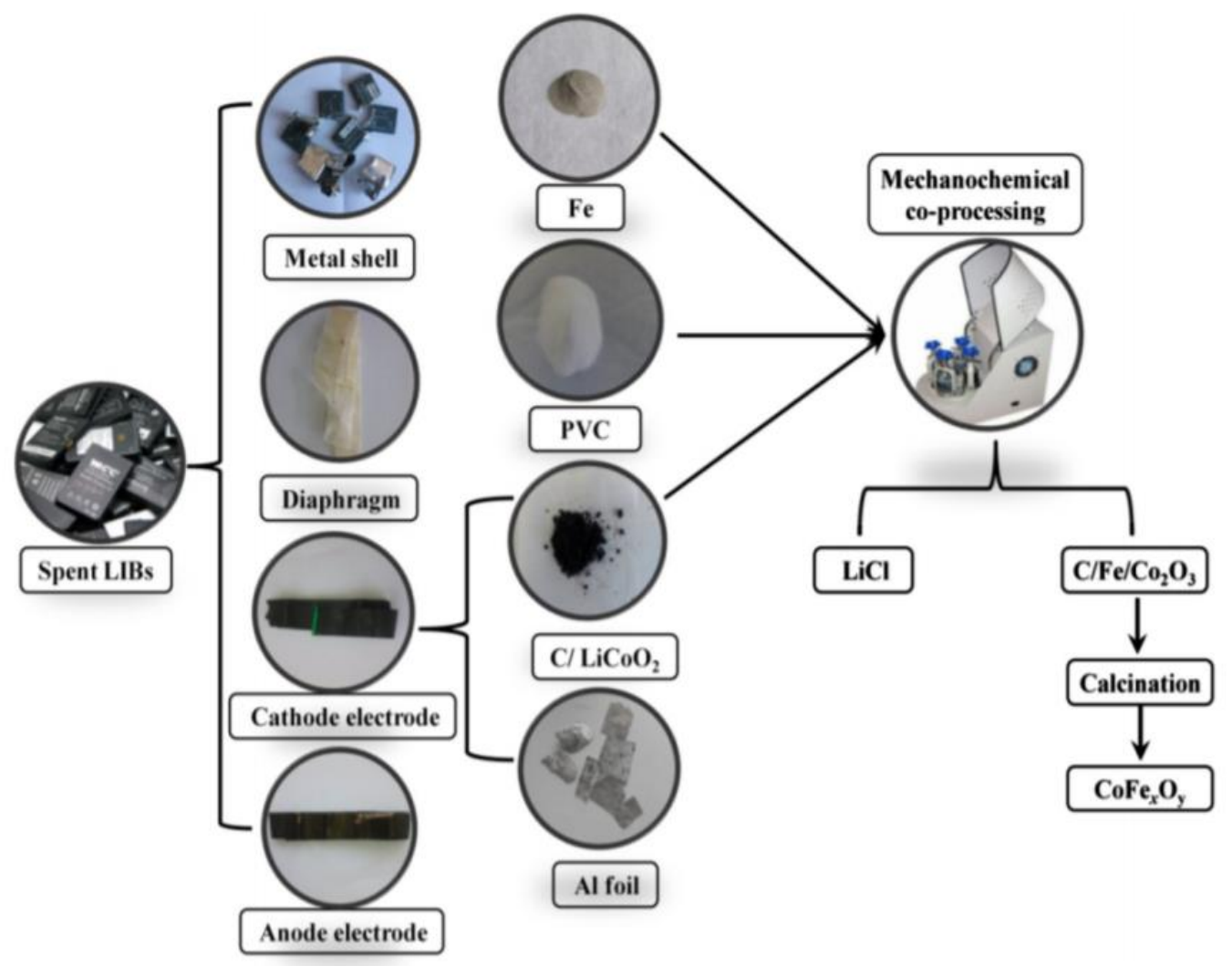

Figure 19 - Process flow of the mechanochemical method for recycling of used LIBS [193].

The production of Manganese oxide cathodes is an interesting approach, as it presents some advantages for the recycling process. These electrodes are binder-free, which means that there is one less component to recover. Also, when thermal treatment is applied, the material recovers nearly its original properties. With an initial discharge capacity of 115 $\mathrm{mAh} . \mathrm{g}^{-1}$, and a loss of $72 \mathrm{mAh} . \mathrm{g}^{-1}$ after 50 cycles, the regeneration process allowed a recovery for the $101 \mathrm{mAh} \cdot \mathrm{g}^{-1}$. The process can be repeated several times without efficiency loss, making manganese oxide cathodes a promising candidate for green and easily recyclable batteries in the future [125].

A new method, named direct recovery, was developed to overcome the challenges of the cost of recycling processes, that demand high energy consumption and expensive reagents. Direct recovery is a simple technique, consisting in the bathing of the cathode in a chemical solution to regenerate it by changing its chemical composition. This 
technique is very appealing, as it has the advantages of being a low-temperature process that uses less energy and has lower emissions and less waste associated compared with hydrometallurgical and pyrometallurgical processes. Direct recovery is a low-cost technique, which contributes to several money savings [246]. The re-synthesis of spent $\mathrm{LiCoO}_{2}$ with a process of leaching followed up by sol-gel method, with calcination at high temperatures, is found to produce excellent cycle life performance in regenerated batteries [190].

\subsubsection{Second life beyond batteries}

Sometimes, there is no need to reuse the battery spent materials in the same application. Some applications require a simpler reconversion of the materials, making them more attractive for the recycling of spent materials. The active material lithium cobalt oxide can be recycled from wasted LIBs and transformed into an electrocatalyst for oxygen evolution reaction with improved properties, such as higher current density (after 500 cycles of charge and discharge) in comparison with pristine active materials [247]. Decomposition of methylene blue dye can be effectively achieved by photo Fenton [248] reaction, using re-synthesised $\mathrm{CoFe}_{2} \mathrm{O}_{4}$ from spent LIBs [248]. Citric acid is also effective in the recovery of compounds with good photocatalytic properties [249].

Recovered cobalt from the acid dissolution of $\mathrm{LiCoO}_{2}$ can be used for electrodeposition in solid oxide fuel cells, enhancing their electrical and morphological properties [250]. Spent cathodes were used to develop a new anode for oxygen evolution reaction. After thermal treatment, graphite was added to the remaining $\mathrm{LiCoO}_{2}$ and $\mathrm{Co}_{3} \mathrm{O}_{4}$ from the cathode to produce the new electrode [251]. Spent $\mathrm{LiCoO}_{2}$ cathode powders can be used to treat waste waters, particularly to remove sulphur pollutants [252]. These powders are also effective in the removal of levofloxacin hydrochloride in waste waters [253]. Heavy metals in polluted waters can be also removed with powders from spent $\mathrm{LiFePO}_{4}$ cathodes by alkaline leaching process [254]. The application of spent cathode materials in the removal of oxygenated VOCs was studied and proved successfully, by the synthesis of manganese and cobalt based metal oxides catalysts [255].

Another example is the preparation of magnetic NiCo ferrite nanocrystalline particles, manufactured by sol-gel combustion, from wasted LIBs. It is interesting to note that, the variation of the temperature of the calcination process can lead up to controlled changes in the magnetic properties of these ferrites, which can be integrated as high-quality 
materials for high-density recording devices, high frequencies devices and magnetic refrigerators [241].

\subsubsection{Recovery of anode materials}

Typically, the recycling of the anode is based on the recovery of carbonaceous materials, with different methods, such as hydrometallurgical and thermal, as presented in Table 4. Cobalt can be recycled with a hydrometallurgical method, consisting of alkali leaching, reductive acid leaching and chemical deposition of cobalt oxalate. Next, cobalt oxalate can be used for the synthesis of nano- $\mathrm{Co}_{3} \mathrm{O}_{4}$ as active anode material [226].

The recycling of single-wall carbon nanotubes using acid and thermal treatments has proven economically viable, with the costs of the recovery being significantly lower (50$75 \%$ ) than the costs of the synthesis of new nanotubes from raw sources [256].

Some materials from other applications can be successfully recycled and reused in LIBs. Slurry wastes from photovoltaics solar cells are good candidates to produce silica-based active materials for anodes [257-259]. This silica can also be obtained in rice husks, that possess large amounts of nanoporous silica layers in their constitution, which allied to the massive rice production worldwide, presents a significant source of silica for application in anodes [260]. Carbon-based active materials can be recycled from various sources, such as tier-rubber- derived materials [261], bioalgal biomass residues [262], pyrolysed fly ash [263], windshield glass of vehicles [264] and spent lead-acid batteries, for being used as anode material [218]. The study of recycled $\mathrm{CuCl}$ powders proved that the reuse of this material as the active anode material is viable, with a discharge capacity of 171.8 mAh. $\mathrm{g}^{-1}$ at $2 \mathrm{C}$ rate [265]. $\mathrm{CuCl}$ can also be recycled from spent printed circuit boards, using liquid-phase chemical reduction, and then used as anode material in LIBs with satisfactory performance [266]. 
Table 4 - Advantages and disadvantages of each reported recycling process for anode materials.

\begin{tabular}{|c|c|c|c|c|c|c|c|}
\hline Initial material & Process & Conditions & $\begin{array}{l}\text { Obtained } \\
\text { Material }\end{array}$ & \begin{tabular}{|c|}
$\begin{array}{c}\text { Efficiency } \\
(\%)\end{array}$ \\
\end{tabular} & Advantages & Disadvantages & Ref \\
\hline $\begin{array}{c}\text { Single-wall } \\
\text { carbon nanotubes }\end{array}$ & $\begin{array}{l}\text { Acid } \\
\text { reflux/HCl } \\
\text { acid }\end{array}$ & $\begin{array}{c}\text { Addition of } \\
\mathrm{HCl} \text { and } \\
\mathrm{HNO}_{3} ; \\
\text { vacuum } \\
\text { filtration } \\
\end{array}$ & $\begin{array}{l}\text { Single-wall } \\
\text { carbon } \\
\text { nanotubes }\end{array}$ & - & Low cost & $\begin{array}{c}\text { Loss of } \\
\text { charge/discharge } \\
\text { efficiency }\end{array}$ & [256] \\
\hline Graphite & $\begin{array}{c}\text { Acid } \\
\text { leaching }\end{array}$ & filtration & Graphite & $>99.5$ & $\begin{array}{l}\text { High recovery } \\
\text { rates }\end{array}$ & $\begin{array}{c}\text { High } \\
\text { temperatures }\end{array}$ & [230] \\
\hline Graphite & $\begin{array}{l}\text { Fenton } \\
\text { reagent } \\
\text { assisted } \\
\text { flotation } \\
\text { process } \\
\end{array}$ & $\begin{array}{c}\mathrm{Fe}^{2+} / \mathrm{H}_{2} \mathrm{O}_{2} \\
\text { ratio is } \\
1: 120\end{array}$ & Graphite & - & $\begin{array}{l}\text { Room } \\
\text { temperature }\end{array}$ & Toxic solvents & [202] \\
\hline Graphite & $\begin{array}{l}\text { Ultrasonic } \\
\text { vibration } \\
\text { and sieving }\end{array}$ & $\begin{array}{l}\text { Nitrogen } \\
\text { atmosphere } \\
\text { at } 1673 \mathrm{k} \\
\text { for } 4 \mathrm{~h} \\
\end{array}$ & Graphite & 99.5 & $\begin{array}{l}\text { High recovery } \\
\text { rates }\end{array}$ & $\begin{array}{l}\text { High } \\
\text { temperatures }\end{array}$ & [267] \\
\hline Graphite & \begin{tabular}{|l|} 
Electrolysis/ \\
Precipitation
\end{tabular} & $\begin{array}{c}\text { Addition of } \\
\mathrm{Na}_{2} \mathrm{SO}_{4}\end{array}$ & Graphite & - & $\begin{array}{c}\text { High purity } \\
\text { materials }\end{array}$ & $\begin{array}{l}\text { High voltages } \\
\text { needed }\end{array}$ & [268] \\
\hline Graphite & $\begin{array}{l}\text { Sonication/ } \\
\text { acid } \\
\text { leaching }\end{array}$ & $\begin{array}{c}\text { Thermal } \\
\text { treatment at } \\
500^{\circ} \mathrm{C} \\
\text { Addition of } \\
\mathrm{H}_{2} \mathrm{SO}_{4} \\
\end{array}$ & Graphite & 99 & High purity & $\begin{array}{l}\text { High } \\
\text { temperatures }\end{array}$ & [269] \\
\hline
\end{tabular}

Graphite is widely used as the anode on LIBs. Recovering battery-grade graphite from used LIB anodes is difficult due to the physicochemical changes occurring to graphite during battery operation. These changes include surface modification of graphite electrodes, graphite oxidation, formation of a solid electrolyte interface (SEI) and cointercalation of solvent molecules into the structure of graphite [270]. One solution to this problem is the recovery of graphite from other applications outside LIBs. Alternatively, graphite material may be recycled as graphene by a facile treatment of electrolysis. This treatment included a charge to $2.3 \mathrm{~V}$ in a 120 cycled cell and the electrolysation of the cell during 10 hours using aluminium anode and molybdenum cathode. Finally a last step of ultrasonic cleaning was applied in the cathode material during one hour [271]. Ultrasonic recovery of graphite is achieved by simple ultrasonic vibration in nitrogen atmosphere at high temperatures. This process allows not only the recovery or the graphite but also the 
separation of the copper [267]. Anode recycling can include electrolysis processes to remove the $\mathrm{Cu}$ foil, and precipitation with $\mathrm{Na}_{2} \mathrm{SO}_{4}$ to recover the graphite that can be used in new batteries with excellent cycling stability and high coulombic efficiency [268]. The spent graphite can also be reconverted in 2D graphene oxide that can be used for other applications, using a modified Hummers method [272]. Similarly to cathode materials, acid leaching with $\mathrm{H}_{2} \mathrm{SO}_{4}$ can also be used to recover the graphite, for posterior uses [269].

\subsubsection{Separator/electrolyte}

Recycling the electrolyte of LIBs is a critical concern. Liu et al. [273] reported a method based in a supercritical $\mathrm{CO}_{2}$ extraction, resin, and molecular sieve purification, can contribute to producing a regenerated high ionic conductivity electrolyte, almost close to the commercial ones. Figure 20 represents the steps involved in this proposed method, which are supercritical $\mathrm{CO}_{2}$ extraction to separate the electrolyte, followed by its collection and purification in a glovebox under argon atmosphere. Then the collected electrolytes were electrochemically evaluated, and finally, batteries were assembled and tested. This process leads up to the production of new batteries with satisfactory electrochemical performance [273].

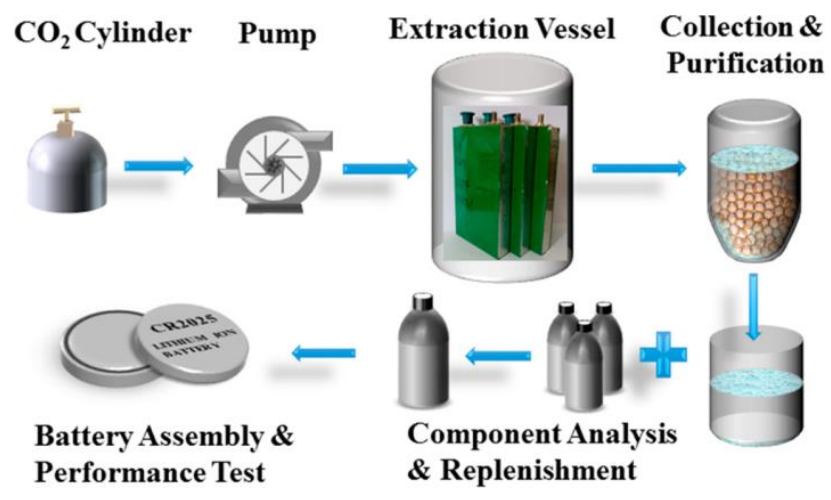

Figure 20 - Schematic representation of reclaimed electrolytes produced from spent LIBs [273].

Electrolytes are a vital component in LIBs. However, their toxic and harmful nature makes the recovery of electrolytes an important environmental issue. An environmentally friendly process to recover electrolyte solutions using extraction with transcritical $\mathrm{CO}_{2}$ was proposed by Mu et. al. This method uses free solvent residues and allows the recovery of organic carbonate solvents from the electrolytes. Pressure plays a crucial role in the 
efficiency of the process during extraction, yielding higher efficiencies at higher pressures. On the other hand, lower temperatures increase extraction rates [274].

Electrolyte recovery by cell immersion in a suitable solvent for a few hours has been demonstrated [275]. Different solvents can be used, as long as their boiling point at reduced pressure is below the lithium salt decomposition temperature $\left(\sim 80^{\circ} \mathrm{C}\right)$, so that anhydrous electrolyte may be recovered.

Separators can be recovered using a pneumatic separation method, with an efficiency of about $98 \%$, that avoids the disposal of plastic pollutants. The optimization of the conditions, with flow velocities between $3 \mathrm{~cm} / \mathrm{s}$ and $7.8 \mathrm{~m} / \mathrm{s}$, leads to better recovery efficiency rates [276].

\section{Electric vehicle: a case study}

Fully battery-powered electric vehicles, which have been considered a promising alternative to internal combustion engine (ICE) vehicles, are finally gaining broad consumer interest thanks to the fast-paced progress in battery technology over the recent years.

It is expected that most of the expected LIB capacity over the next years will be applied to electric vehicles (EV) [99]. As such, it is of great importance to analyse the environmental impact of LIB when used in this application. A more realistic view of the EV environmental impact needs to consider both the impacts throughout the EV life, including during driving. LCA analysis can aid in making informed decisions and recommendations that ensure a sustainable transport sector with a focus on greenhouse gas emissions and energy use.

Electrified transportation offers significantly better energy efficiency over older technologies, namely ICE vehicles. Thus, although highly dependent on the driving style, the energy efficiency of electric vehicles ranges between $75-82 \%$, compared to the meagre 16-25\% efficiency of ICEs [277-279]. On top of this, EV drivetrains are much simpler in design and have significantly fewer moving parts compared to ICE drivetrains, which brings additional economical (lower maintenance) and environmental gains [280]. Results from different studies [281, 282] differ on the question of greenhouse gas emissions from electric cars, generally focusing on the use phase and how EVs contribute to the emissions when driving.

Figure 21 summarises the different stages considered in a LIB life cycle assessment. Interactions are shown between the different phases, considering their normal lifespan 
flow (production, to use and then end-of-life), as well as new relations that recycling and second-life utilisation brings to the life cycle assessment.

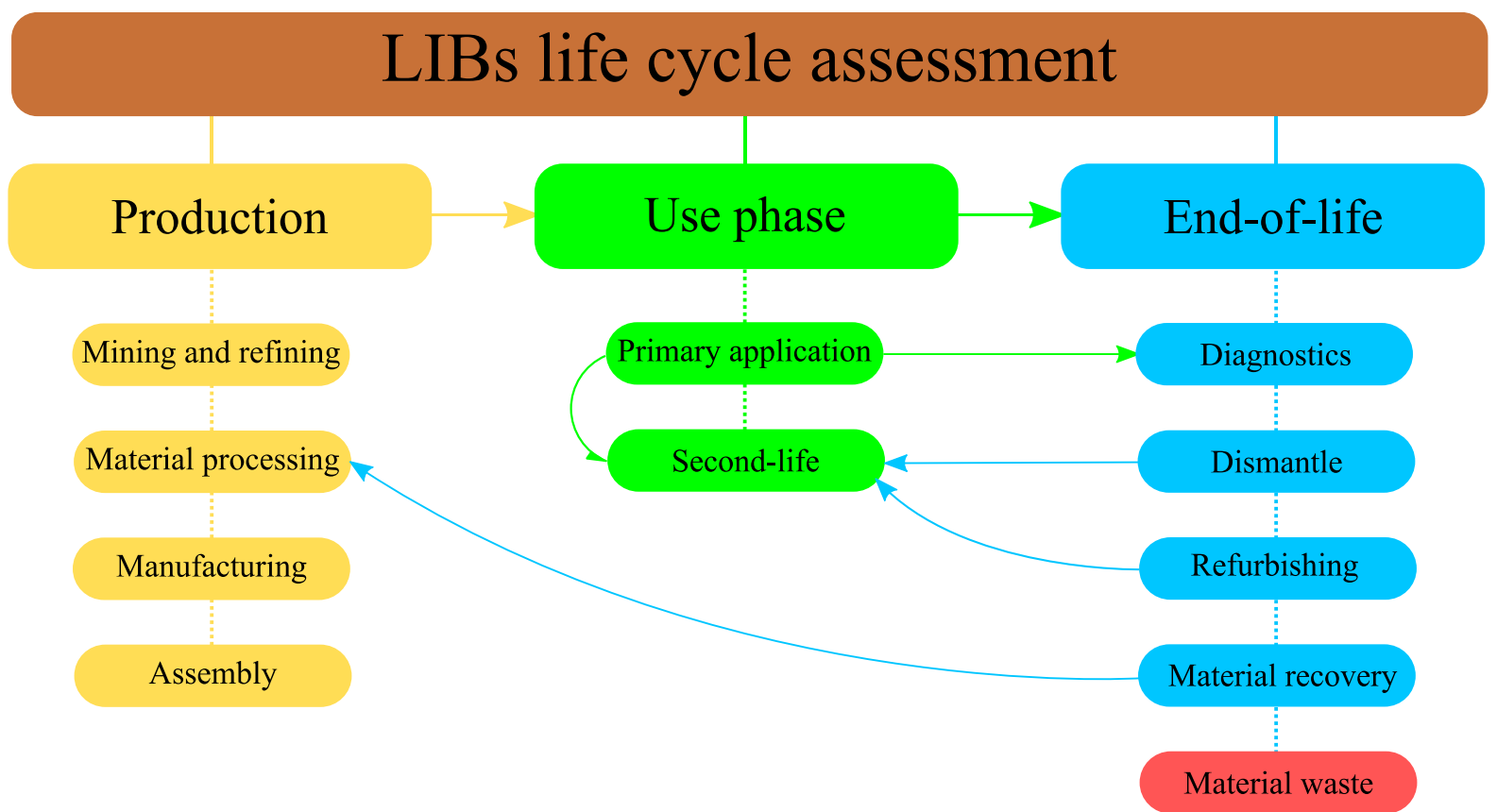

Figure 21. LIB life cycle assessment diagram and the relations between the different stages.

\subsection{Battery production}

Several works [283-287] have studied greenhouse gas emission during the LIB production stage with substantially different results, mainly due to uncertainty of production as a result of sparse data and pilot-scale methods, differences in material data modelling and approximation of materials to similar ones, and electricity mix.

The electricity mix is a critical factor for greenhouse gas emissions at the production stage. According to Romare et al. [288], manufacturing contributes significantly (45$60 \%$ ) to the total emissions in the production stage, mainly by electricity use, indicating that production site electricity mix is one of the main factors affecting the overall environmental impact of the EV. Assuming a fossil fuel share in manufacturing in the range of $50-70 \%$, it turns out that the contribution of mining and refining to the carbon footprint of LIBs is relatively small (despite the significant environmental impact of fossil fuels). Thus, as the impact of the electricity mix in the production stage depends on the location of the production plants, the emissions from the electricity can vary significantly between countries. The study concludes that greenhouse gas emissions of $150-200 \mathrm{~kg}$ $\mathrm{CO}_{2}$-eq/kWh battery correspond to the greenhouse gas burden of current battery 
production, and that it is nearly independent of the cell chemistry (NMC, LFP or LMO) [288].

\subsection{Use phase}

EV powertrains LIBs do not produce direct emissions in the use phase, which is why they are considered an eco-friendly alternative to internal combustion engine (ICE) vehicles. Furthermore, typical battery-powered EV drivetrains have 90\% fewer moving parts [289], require no maintenance such as oil changes or timing belts, and their ability to use regenerative braking saves energy and makes their brake pads last longer, further lowering the usage emissions when compared with ICE vehicles.

However, EVs produce emissions indirectly through the energy sources used to recharge the batteries. Again, the local energetic mix source and their associated emissions are essential to estimate if the environmental impact from use phase emissions footprint may be as bad as that of ICEs.

\subsection{Second-life}

The continuous growth in EV sales brings about a new question: what do we do with those LIBs that are unsuitable for EV powertrains? Batteries are removed from service due to the capacity loss produced by continuous cycling. It is estimated that after 8 to 10 years of service in $\mathrm{EV}$, batteries no longer to meet the power range required by their users. At that point, however, used EV powertrain batteries still retain about $70-80 \%$ of their original capacity. This allows prolonging the life of the batteries by reusing them in less demanding applications - giving them a second-life. Applications such as residential and industrial energy storage, grid stabilisation and storage, mobile energy storage, powertrains for low-speed electric vehicles and forklifts and utility-scale battery storage are the primary examples of potential second-lives for retired LIBs.

Some reports [290] estimate that second-life battery capacity will reach 275 GWh per year by 2030 due to the mass adoption of the EV as eco-friendlier transportation. As the adoption of the EVs started to get noticeable sales to the public in 2010 going forward, the first batch of EV LIBs is reaching their end-of-life status, contributing to a foreseeable increase in the volume of retired batteries.

Currently, several pilot initiatives bring new applications for retired LIBs, away from their primary application. Table 5 summarises some of the second-life initiatives presented by EV manufacturers. 
Table 5 -Second-life initiatives proposed by EV manufacturers for retired EV LIBs.

\begin{tabular}{|c|c|c|c|}
\hline Designation & Promoters & Application segment & Ref. \\
\hline xStorage & Nissan, Eaton & $\begin{array}{l}\text { Residential and } \\
\text { buildings energy } \\
\text { storage, grid }\end{array}$ & [291] \\
\hline 4R Energy & Nissan, 4R Energy & $\begin{array}{l}\text { Residential and } \\
\text { buildings energy } \\
\text { storage }\end{array}$ & [236] \\
\hline ELSA & $\begin{array}{c}\text { The ELSA Consortium } \\
\text { (Nissan, Renault, AÜW, } \\
\text { European Union's Horizon } \\
\text { 2020) }\end{array}$ & $\begin{array}{l}\text { Residential, buildings } \\
\text { and energy industrial } \\
\text { storage, grid }\end{array}$ & {$[237]$} \\
\hline The Light Reborn & Nissan & Lighting & [238] \\
\hline Nissan-FreeWire & Nissan, FreeWire & Mobile energy storage & [239] \\
\hline $\begin{array}{l}\text { Commercial energy } \\
\text { storage powered by } \\
\text { second-life batteries } \\
\end{array}$ & Nissan, Green Storage & Grid & {$[240]$} \\
\hline $\begin{array}{l}\text { Second-life battery } \\
\text { storage for fast- } \\
\text { charging stations } \\
\end{array}$ & Renault, Connected Energy & $\begin{array}{l}\text { Utility-scale battery } \\
\text { storage }\end{array}$ & [241] \\
\hline $\begin{array}{l}\text { Second-life smart } \\
\text { home battery }\end{array}$ & Renault, Powervault & $\begin{array}{l}\text { Residential energy } \\
\text { storage }\end{array}$ & {$[242]$} \\
\hline Daimler-BAIC & Daimler, BAIC & Grid & {$[243]$} \\
\hline $\begin{array}{l}\text { BMW's second-life } \\
\text { battery farm in } \\
\text { Leipzig } \\
\end{array}$ & BMW & Grid & [244] \\
\hline $\begin{array}{c}\text { Second-life BMW } \\
\text { batteries connected to } \\
\text { UC San Diego's grid }\end{array}$ & BMW, EVgo & $\begin{array}{l}\text { Residential energy } \\
\text { storage, grid }\end{array}$ & {$[245]$} \\
\hline $\begin{array}{l}\text { Second-Life } 2.8 \mathrm{MWh} \\
\text { Energy Storage } \\
\text { Solution in Hamburg }\end{array}$ & BMW, Bosch & $\begin{array}{l}\text { Grid, fast-chargers } \\
\text { energy storage }\end{array}$ & [246] \\
\hline $\begin{array}{c}\text { Hybrid Car Batteries } \\
\text { in Yellowstone }\end{array}$ & Toyota & $\begin{array}{l}\text { Lighting, residential } \\
\text { energy storage }\end{array}$ & {$[247]$} \\
\hline $\begin{array}{c}\text { Electrified Vehicle } \\
\text { Battery Reuse and } \\
\text { Recycling Verification } \\
\text { Project } \\
\end{array}$ & $\begin{array}{c}\text { Toyota, Chubu Electric } \\
\text { Power }\end{array}$ & Grid & {$[248]$} \\
\hline $\begin{array}{c}\text { Wärtsilä and Hyundai } \\
\text { energy storage } \\
\text { partnership }\end{array}$ & Hyundai, Wärtsilä & $\begin{array}{l}\text { Utility-stage and } \\
\text { commercial energy } \\
\text { storage }\end{array}$ & [249] \\
\hline $\begin{array}{l}\text { 360-kWh Mobile } \\
\text { Charging Station }\end{array}$ & Volkswagen & Mobile energy storage & [250] \\
\hline
\end{tabular}


The LIBs second-life environmental impact is difficult to quantify but extending the useful life of LIBs beyond their original application can reduce the overall impact. The value of second-life batteries is determined by several factors, namely battery design, their condition after their first life, the intended use for the battery in its second-life and the cost/value of recycling. Additionally, there are economic, technical and regulatory factors that impact the difficulty for companies to profit from second-life batteries.

However, given that batteries are the most expensive component of an EV, the potential value for retired LIBs remains high as their reuse becomes economically appealing. However, the difficulties in the quality assurance of retired batteries lead to business concerns about the possibility of ending up with lower quality products in second-life applications for other applications, such as mobile phones, computers, and sensors.

\subsection{End-of-life}

According to a study on the economic feasibility of end of life vehicle LIBs [292], there are three ways to create value from used batteries at the end of their life in electric vehicles because the battery may still be able to store a significant energy level. These options are remanufacturing, repurposing and recycling.

Remanufacturing processes consist in repairing the battery by the replacement of damaged cells and keeping it in use for continuous integration in electric vehicles.

Repurposing by reengineering is a process in which the battery is repaired and then put to a different use than the original one. This includes, for example, integration in stationary systems of renewable energy storage. Last, recycling involves the disassembly of all the components of the battery, safely recovering them, and thus reusing the valuable metals for the synthesis of regenerated materials and batteries.

\subsubsection{Remanufacturing}

Remanufacturing of spent LIBs to recover their charge/discharge capacity is an important step to reduce the need for new materials extraction and processing. A cost-benefit analysis showed that remanufacturing a battery could save about $60 \%$ of the total cost of production of a new battery [293]. Moreover, it is estimated that a remanufacturing rate of $55 \%$ can lead to a reduction of the new batteries production needs in $10 \%$ [294]. 


\subsubsection{Repurposing}

As shown in Figure 21, to use the LIBs in second-life applications, it is essential to diagnose the batteries on removal from the vehicle at the end of their primary application, particularly in terms of their capacity, safety and structural condition. Afterwards, dismantling and refurbishing may be needed depending on the LIBs design and the second-life application at hand. Nonetheless, some initiatives already project the LIBs considering their subsequent second-life application [252]. In this case, a packed module and battery management system was designed to seamlessly transition from vehicle energy storage to stationary energy storage at the end of their vehicle life. Thus, battery design can be optimised not only for their primary application but also for their intended second-life application, minimising or even excluding adaptation work between applications.

\subsubsection{Recycling}

End-of-life treatment can provide the recycling of materials and can be advantageous from both the environmental and resource conservation perspectives. During this phase, recycled materials can replace primary materials, supporting the preservation of natural resources and lowering environmental impact than virgin materials [295].

Recycling of LIB is currently low, mainly driven by legislation. European Union directives regulate environmental regulations, such as end-of-life directives, that require automobile manufacturers to extend the responsibility of their vehicles and products beyond the use phase (directive 2000/53/EC). Car manufacturers are responsible for taking back their products with the end goal of reusing or recycling. Furthermore, Directive 2006/66/EC stipulates minimum recycling rates to minimise the negative impact of batteries and waste batteries on the environment. Specifically, $45 \%$ of spent LIBs must be collected, and at least $50 \%$ of the average weight of LIBs should be recycled, excluding energy recovery. This way, the current battery recycling market is driven by legislation and metal value.

There are several technologies and combinations of technologies in use or being developed. First, the EV battery packs are disassembled, due to safety reasons, also facilitating the recycling of battery materials. Individual cells are handled next. Although several technologies could be used to recycling LIB cells, pyro-metallurgical recycling is one of the most used at near commercial scale, while hydrometallurgical methods (tables 
3 and 4) are still in prototype stages in Europe, while one plant in North America that takes larger volumes [296].

The downside of the pyrometallurgical method, however, is the elevated temperatures required (about $1400{ }^{\circ} \mathrm{C}$ ), due to the two options of the pyrometallurgical method: direct vacuum evaporation of lithium, or selective entraining gas evaporation of lithium. Lithium is subsequently recovered either via recovery of lithium metal by distillation in vacuum for 120 minutes at $1400^{\circ} \mathrm{C}$ or in the form of lithium oxide, in the case of the second option of the method [297].

Nowadays, the LIBs used in the automotive industry are not being recycled. One reason could be the relatively low penetration of EVs in the global market, together with the fact that electric vehicles are also made to last the same time of the vehicle itself, so it is expected a lifetime of about 8-10 years for those LIBs, which means that there are not many devices to recycle nowadays. However, soon the situation will change, mainly because of the increase in the electric vehicles market share in recent years.

Batteries used in electric vehicles are considered at the end cycle life when they keep approximately $80 \%$ of their original performance. Packs of these batteries can be reconverted and applied in energy storage systems. This application can duplicate the life cycle of these devices. However, the batteries need to undergo a reconversion process to change their purpose from transportation to stationary use [298]. 


\section{Final remarks}

The increasing relevance of LIBs is strongly related to interconnectivity and mobility, being present in many daily used electronic mobile devices. With the current development of the electric mobility the demand for more efficient and sustainable LIBs will rise in the coming years. This increase in demand boosts the prices of scarce materials such as cobalt, nickel and lithium, to name the most critical ones. Mining, extraction and purification of these metals to battery-grade quality are highly damaging from an environmental viewpoint. Despite all the effort required to produce those LIBs, the valuable materials involved are landfilled and become irrecoverable only a couple of years later. To make matters worse, the environment is damaged further as electronic waste, which includes LIBs, is one of the most polluting on earth.

Battery recycling is, therefore, an urgent financial and environmental obligation. Recycling begins with the consideration of giving batteries a second life before dismantling. Most cells still hold over $80 \%$ of their original capacity at the time of their disposal. They are, by no means, useless. Some examples of second-life applications are powertrains for low-speed vehicles or residential and industrial energy storage. It is at their end of life that they can be taken apart to recover their highly valuable components and materials. At this stage, battery condition is newly assessed to decide the most suitable recycling approach. The main options are so-called pyro- and hydrometallurgical methods and direct recycling. Pyro- and hydrometallurgical processes aim to recover the raw materials used in the batteries, particularly the metals, so that they can be used again in the production of new cells, or even in other applications that require the same metals. This path allows for high metal recovery rates (above 90\%), but it requires high energy and hazardous materials consumption. In contrast, the latter view is about refurbishing some of the battery components, such as the cathode, to be assembled in new batteries. In this case, there is no need to produce a new battery component, reducing the overall energy and hazardous materials consumption, when compared with direct recycling. However, this approach results in lower battery performance. Therefore, pyro- and hydrometallurgical methods are measured in terms of recovery rates, and direct recycling methods are assessed in terms of battery performance. In an environmental context, the main objective must be the reduction of landfill disposal, by incentive the second use of batteries, and adopting recycling strategies after reaching the battery end of life. In the latter, it is relevant to place the recycled materials in advanced stages of the value chain. This means that the early stages of the chain value (mining, refining, production) can be 
reduced both at the energetic and material consumption levels, leading to a more sustainable and circular economy model.

However, the production of new batteries is not always the goal. Some parts may find applications outside energy storage field. For example, cathodes may work as catalysts for the degradation of organic material, or as absorbents for heavy metal contaminants. This work has reported on the most common recycling methods for all battery components, with a focus on cathode active materials. The most studied recycling method is hydrometallurgical, in particular with acid leaching processes. While they lead to high recovery rates, they can be environmentally harmful due to the chemicals involved in the process. In contrast, pyrometallurgical processes operate at high temperatures and are usually associated with high atmospheric emissions.

One of the issues facing the recycling of LIBs is the wide variety of cell designs in terms of materials and construction. This diversity makes it very hard to come up with a valid "universal" recycling process. Perhaps, this is one of the areas where legislation can act to support and encourage the adequate disposal and recycling of LIBs. For instance, directives and national acts regulate the recycling of lead-acid batteries. The reason may be that these devices have been in the market for a long time, but the use of LIBs will continue to grow. Because legislation alone does not work, consumers need to be aware of the importance of recycling, both in economic and environmental terms. Also, business actors need to be able to find the right incentives to re-design or reengineer the battery supply chain into a closed loop. More environmentally friendly materials and processes can be used to create value. In this sense, life cycle assessment, LCA, methods, can be a great assessment tool. The emerging industry of the electric vehicle, EV, represents a huge opportunity to do the right things from the early stages. The rapid shift from petrol to batteries will make it a necessity in the immediate future. Ideally, this should be an international effort addressing the complete LIB supply chain because the environmental and economic implications are global. Mining and purifying scarce metals such as cobalt, nickel and lithium will continue to be necessary. However, recycling can protect the environment by acting as a buffer for the demand of raw materials of natural origin. Thus, recycling LIBs will take a critical role by satisfying a significant part of the lithium demand in future years. 


\section{Acknowledgements}

The authors thank the FCT (Fundação para a Ciência e Tecnologia) for financial support under the framework of Strategic Funding grants UID/FIS/04650/2020, UID/EEA/04436/2020 and UID/QUI/0686/2020; and project PTDC/FISMAC/28157/2017. The authors also thank the FCT for financial support under grants SFRH/BD/140842/2018 (J.C.B.) and SFRH/BPD/112547/2015 (C.M.C.) and Investigator FCT Contract CEECIND/00833/ 2017 (R.G.) as well POCH and European Union. Financial support from the Basque Government Industry and Education Departments under the ELKARTEK, HAZITEK and PIBA (PIBA-2018-06) programs, respectively, are also acknowledged.

\section{References}

[1] Goyal MR, Eilu E. Digital Media and Wireless Communications in Developing Nations: Agriculture, Education, and the Economic Sector: Apple Academic Press; 2019. [2] Akcil A. Critical and Rare Earth Elements: Recovery from Secondary Resources: CRC Press; 2019.

[3] Brown LR, Adams E, Larsen J, Roney JM. The Great Transition: Shifting from Fossil Fuels to Solar and Wind Energy: W. W. Norton; 2015.

[4] Sun X, Hao H, Zhao F, Liu Z. Tracing global lithium flow: A trade-linked material flow analysis. Resources, Conservation and Recycling. 2017;124:50-61.

[5] Lu B, Liu J, Yang J. Substance flow analysis of lithium for sustainable management in mainland China: 2007-2014. Resources, Conservation and Recycling. 2017;119:10916.

[6] Li L, Zhang X, Li M, Chen R, Wu F, Amine K, et al. The Recycling of Spent LithiumIon Batteries: a Review of Current Processes and Technologies. Electrochemical Energy Reviews. 2018;1:461-82.

[7] Mohr S, Mudd G, Giurco D. Lithium Resources and Production: Critical Assessment and Global Projections. Minerals. 2012;2.

[8] Gaines L. Lithium-ion battery recycling processes: Research towards a sustainable course. Sustainable Materials and Technologies. 2018;17:e00068. 
[9] Oliveira L, Messagie M, Rangaraju S, Sanfelix J, Hernandez Rivas M, Van Mierlo J. Key issues of lithium-ion batteries - from resource depletion to environmental performance indicators. Journal of Cleaner Production. 2015;108:354-62.

[10] Heelan J, Gratz E, Zheng Z, Wang Q, Chen M, Apelian D, et al. Current and Prospective Li-Ion Battery Recycling and Recovery Processes. JOM. 2016;68:2632-8.

[11] Song X, Hu S, Chen D, Zhu B. Estimation of Waste Battery Generation and Analysis of the Waste Battery Recycling System in China. Journal of Industrial Ecology. 2017;21:57-69.

[12] Gu F, Guo J, Yao X, Summers PA, Widijatmoko SD, Hall P. An investigation of the current status of recycling spent lithium-ion batteries from consumer electronics in China. Journal of Cleaner Production. 2017;161:765-80.

[13] Sencanski J, Vujkovic M, Stojkovic I, Majstorovic D, Bajuk-Bogdanovic D, Pastor $\mathrm{F}$, et al. Recycling of $\mathrm{LiCo} 0.59 \mathrm{Mn} 0.26 \mathrm{Ni0} .15 \mathrm{O} 2$ cathodic material from spent Li-ion batteries by the method of the citrate gel combustion. Hemijska industrija. 2017;71:21120 .

[14] Prior T, Wager PA, Stamp A, Widmer R, Giurco D. Sustainable governance of scarce metals: the case of lithium. Sci Total Environ. 2013;461-462:785-91.

[15] Dewulf J, Van der Vorst G, Denturck K, Van Langenhove H, Ghyoot W, Tytgat J, et al. Recycling rechargeable lithium ion batteries: Critical analysis of natural resource savings. Resources, Conservation and Recycling. 2010;54:229-34.

[16] Waldmann T, Iturrondobeitia A, Kasper M, Ghanbari N, Aguesse F, Bekaert E, et al. Review-Post-Mortem Analysis of Aged Lithium-Ion Batteries: Disassembly Methodology and Physico-Chemical Analysis Techniques. Journal of The Electrochemical Society. 2016;163:A2149-A64.

[17] Wang X, Gaustad G, Babbitt CW, Bailey C, Ganter MJ, Landi BJ. Economic and environmental characterization of an evolving Li-ion battery waste stream. J Environ Manage. 2014;135:126-34.

[18] Wang X, Gaustad G, Babbitt CW, Richa K. Economies of scale for future lithiumion battery recycling infrastructure. Resources, Conservation and Recycling. 2014;83:5362.

[19] Asari M, Sakai S-i. Li-ion battery recycling and cobalt flow analysis in Japan. Resources, Conservation and Recycling. 2013;81:52-9.

[20] Park M, Zhang X, Chung M, Less GB, Sastry AM. A review of conduction phenomena in Li-ion batteries. Journal of Power Sources. 2010;195:7904-29. 
[21] Aral H, Vecchio-Sadus A. Toxicity of lithium to humans and the environment-A literature review. Ecotoxicology and Environmental Safety. 2008;70:349-56.

[22] Placke T, Kloepsch R, Dühnen S, Winter M. Lithium ion, lithium metal, and alternative rechargeable battery technologies: the odyssey for high energy density. Journal of Solid State Electrochemistry. 2017;21:1939-64.

[23] Kavanagh L, Keohane J, Garcia Cabellos G, Lloyd A, Cleary J. Global Lithium Sources-Industrial Use and Future in the Electric Vehicle Industry: A Review. Resources. 2018;7:57.

[24] Hallmann L, Ulmer P, Kern M. Effect of microstructure on the mechanical properties of lithium disilicate glass-ceramics. Journal of the Mechanical Behavior of Biomedical Materials. 2018;82:355-70.

[25] Wang Z, Orejon D, Sefiane K, Takata Y. Water vapor uptake into hygroscopic lithium bromide desiccant droplets: mechanisms of droplet growth and spreading. Physical Chemistry Chemical Physics. 2019;21:1046-58.

[26] Mendoza-Duarte JM, Sagarnaga-Fernandez M, Moreno-Resendiz EG, MedranoPrieto HM, Estrada-Guel I, Garay-Reyes CG, et al. Aluminum-lithium alloy prepared by a solid-state route applying an alternative fast sintering route based on induction heating. Materials Letters. 2020;263:127178.

[27] Ahmed M, Naseer MM. Organolithium-mediated cyclization reactions: a practical way to access hetero- and carbocycles. New Journal of Chemistry. 2017;41:7824-35.

[28] Wu X, Zhao G, Wang X, Liu W. Preparation of High-Temperature Lubricants by Blending Castor Oil with Lithium Bis(trifluoromethylsulfonyl)imide. Tribology Letters. 2017;65:51.

[29] Licht RW. Lithium: Still a Major Option in the Management of Bipolar Disorder. CNS Neuroscience \& Therapeutics. 2012;18:219-26.

[30] Costi S, Soleimani L, Glasgow A, Brallier J, Spivack J, Schwartz J, et al. Lithium continuation therapy following ketamine in patients with treatment resistant unipolar depression: a randomized controlled trial. Neuropsychopharmacology. 2019;44:1812-9.

[31] Baumgartner S, Gmeiner R, Schönherr JA, Stampfl J. Stereolithography-based additive manufacturing of lithium disilicate glass ceramic for dental applications. Materials Science and Engineering: C. 2020;116:111180.

[32] Mecklenburg J, Sanchez Del Rio M, Reuter U. Cluster headache therapies: pharmacology and mode of action. Expert Review of Clinical Pharmacology. 2020;13:641-54. 
[33] Goodenough JB. How we made the Li-ion rechargeable battery. Nature Electronics. 2018;1:204-.

[34] Borah R, Hughson FR, Johnston J, Nann T. On battery materials and methods. Materials Today Advances. 2020;6:100046.

[35] Myung S-T, Hitoshi Y, Sun Y-K. Electrochemical behavior and passivation of current collectors in lithium-ion batteries. Journal of Materials Chemistry. 2011;21:9891911.

[36] Li J, Rulison C, Kiggans J, Daniel C, Wood DL. Superior Performance of LiFePO4 Aqueous Dispersions via Corona Treatment and Surface Energy Optimization. Journal of The Electrochemical Society. 2012;159:A1152-A7.

[37] Doberdò I, Löffler N, Laszczynski N, Cericola D, Penazzi N, Bodoardo S, et al. Enabling aqueous binders for lithium battery cathodes - Carbon coating of aluminum current collector. Journal of Power Sources. 2014;248:1000-6.

[38] Laszczynski N, von Zamory J, Kalhoff J, Loeffler N, Chakravadhanula VSK, Passerini S. Improved Performance of VOx-Coated Li-Rich NMC Electrodes. ChemElectroChem. 2015;2:1768-73.

[39] Chen YH, Wang CW, Zhang X, Sastry AM. Porous cathode optimization for lithium cells: Ionic and electronic conductivity, capacity, and selection of materials. Journal of Power Sources. 2010;195:2851-62.

[40] Gören A, Costa CM, Silva MM, Lanceros-Méndez S. State of the art and open questions on cathode preparation based on carbon coated lithium iron phosphate. Composites Part B: Engineering. 2015;83:333-45.

[41] Lee YK. The Effect of Active Material, Conductive Additives, and Binder in a Cathode Composite Electrode on Battery Performance. Energies. 2019;12:658.

[42] Miranda D, Gören A, Costa CM, Silva MM, Almeida AM, Lanceros-Méndez S. Theoretical simulation of the optimal relation between active material, binder and conductive additive for lithium-ion battery cathodes. Energy. 2019;172:68-78.

[43] Zheng H, Yang R, Liu G, Song X, Battaglia VS. Cooperation between Active Material, Polymeric Binder and Conductive Carbon Additive in Lithium Ion Battery Cathode. The Journal of Physical Chemistry C. 2012;116:4875-82.

[44] Huang B, Jang Y-I, Chiang Y-M, Sadoway DR. Electrochemical evaluation of LiCoO2 synthesized by decomposition and intercalation of hydroxides for lithium-ion battery applications. Journal of Applied Electrochemistry. 1998;28:1365-9. 
[45] Yamada A, Chung SC, Hinokuma K. Optimized LiFePO4 for Lithium Battery Cathodes. Journal of The Electrochemical Society. 2001;148:A224-A9.

[46] G. Bruce P, Robert Armstrong A, L. Gitzendanner R. New intercalation compounds for lithium batteries: layered LiMnO2. Journal of Materials Chemistry. 1999;9:193-8. [47] Yabuuchi N, Ohzuku T. Electrochemical behaviors of LiCo1/3Ni1/3Mn1/3O2 in lithium batteries at elevated temperatures. Journal of Power Sources. 2005;146:636-9. [48] Qiu Q-Q, Shadike Z, Wang Q-C, Yue X-Y, Li X-L, Yuan S-S, et al. Improving the Electrochemical Performance and Structural Stability of the LiNi0.8Co0.15Al0.05O2 Cathode Material at High-Voltage Charging through Ti Substitution. ACS Applied Materials \& Interfaces. 2019;11:23213-21.

[49] Yoshio M, Wang H, Fukuda K. Spherical Carbon-Coated Natural Graphite as a Lithium-Ion Battery-Anode Material. Angewandte Chemie International Edition. 2003;42:4203-6.

[50] Chan CK, Peng H, Liu G, McIlwrath K, Zhang XF, Huggins RA, et al. Highperformance lithium battery anodes using silicon nanowires. Nature Nanotechnology. $2008 ; 3: 31-5$

[51] Fransson L, Eriksson T, Edström K, Gustafsson T, Thomas JO. Influence of carbon black and binder on Li-ion batteries. Journal of Power Sources. 2001;101:1-9.

[52] Liu Z, Yu A, Lee JY. Cycle life improvement of LiMn2O4 cathode in rechargeable lithium batteries. Journal of Power Sources. 1998;74:228-33.

[53] Lopez J, Mackanic DG, Cui Y, Bao Z. Designing polymers for advanced battery chemistries. Nature Reviews Materials. 2019;4:312-30.

[54] Lee H, Yanilmaz M, Toprakci O, Fu K, Zhang X. A review of recent developments in membrane separators for rechargeable lithium-ion batteries. Energy \& Environmental Science. 2014;7:3857-86.

[55] Choudhury S, Tu Z, Nijamudheen A, Zachman MJ, Stalin S, Deng Y, et al. Stabilizing polymer electrolytes in high-voltage lithium batteries. Nature Communications. 2019;10:3091.

[56] Bresser D, Buchholz D, Moretti A, Varzi A, Passerini S. Alternative binders for sustainable electrochemical energy storage - the transition to aqueous electrode processing and bio-derived polymers. Energy \& Environmental Science. 2018;11:3096127. 
[57] Barbosa JC, Dias JP, Lanceros-Méndez S, Costa CM. Recent Advances in Poly(vinylidene fluoride) and Its Copolymers for Lithium-Ion Battery Separators. Membranes. 2018;8.

[58] Kyoung Lee C, Rhee K-I. Preparation of LiCoO2 from spent lithium-ion batteries. Journal of Power Sources. 2002;109:17-21.

[59] Zeng F, Xu R, Ye L, Xiong B, Kang J, Xiang M, et al. Effects of Heat Setting on the Morphology and Performance of Polypropylene Separator for Lithium Ion Batteries. Industrial \& Engineering Chemistry Research. 2019;58:2217-24.

[60] Costa CM, Gomez Ribelles JL, Lanceros-Méndez S, Appetecchi GB, Scrosati B. Poly(vinylidene fluoride)-based, co-polymer separator electrolyte membranes for lithium-ion battery systems. Journal of Power Sources. 2014;245:779-86.

[61] Shin Y-K, Kim M-C, Moon S-H, Kim E-S, Lee J-E, Choi S, et al. Pore-controlled polymer membrane with Mn (II) ion trapping effect for high-rate performance LiMn2O4 cathode. Journal of Solid State Electrochemistry. 2019;23:475-84.

[62] Wang S-X, Yap CC, He J, Chen C, Wong SY, Li X. Electrospinning: a facile technique for fabricating functional nanofibers for environmental applications. Nanotechnology Reviews. 2016;5.

[63] Song Q, Li A, Shi L, Qian C, Feric TG, Fu Y, et al. Thermally stable, nano-porous and eco-friendly sodium alginate/attapulgite separator for lithium-ion batteries. Energy Storage Materials. 2019.

[64] Tsao C-H, Su H-M, Huang H-T, Kuo P-L, Teng H. Immobilized cation functional gel polymer electrolytes with high lithium transference number for lithium ion batteries. Journal of Membrane Science. 2019;572:382-9.

[65] Zheng H, Wang Z, Shi L, Zhao Y, Yuan S. Enhanced thermal stability and lithium ion conductivity of polyethylene separator by coating colloidal $\mathrm{SiO} 2$ nanoparticles with porous shell. Journal of Colloid and Interface Science. 2019;554:29-38.

[66] Gonçalves R, Lizundia E, Silva MM, Costa CM, Lanceros-Méndez S. Mesoporous Cellulose Nanocrystal Membranes as Battery Separators for Environmentally Safer Lithium-Ion Batteries. ACS Applied Energy Materials. 2019;2:3749-61.

[67] Pereira RFP, Brito-Pereira R, Gonçalves R, Silva MP, Costa CM, Silva MM, et al. Silk Fibroin Separators: A Step Toward Lithium-Ion Batteries with Enhanced Sustainability. ACS Applied Materials \& Interfaces. 2018;10:5385-94.

[68] Zhang H, Wang X, Liang Y. Preparation and characterization of a Lithium-ion battery separator from cellulose nanofibers. Heliyon. 2015;1:e00032. 
[69] Dai J, Yang C, Wang C, Pastel G, Hu L. Interface Engineering for Garnet-Based Solid-State Lithium-Metal Batteries: Materials, Structures, and Characterization. Advanced Materials. 2018;30:1802068.

[70] Wang Y, Zhong W-H. Development of Electrolytes towards Achieving Safe and High-Performance Energy-Storage Devices: A Review. ChemElectroChem. 2015;2:2236.

[71] Chang P, Mei H, Zhou S, Dassios KG, Cheng L. 3D printed electrochemical energy storage devices. Journal of Materials Chemistry A. 2019;7:4230-58.

[72] Chagnes A. Chapter 5 - Lithium Battery Technologies: Electrolytes. In: Chagnes A, Światowska J, editors. Lithium Process Chemistry. Amsterdam: Elsevier; 2015. p. 16789.

[73] Etacheri V, Haik O, Goffer Y, Roberts GA, Stefan IC, Fasching R, et al. Effect of Fluoroethylene Carbonate (FEC) on the Performance and Surface Chemistry of SiNanowire Li-Ion Battery Anodes. Langmuir. 2012;28:965-76.

[74] Chen L, Wang K, Xie X, Xie J. Effect of vinylene carbonate (VC) as electrolyte additive on electrochemical performance of Si film anode for lithium ion batteries. Journal of Power Sources. 2007;174:538-43.

[75] Sideris PJ, Greenbaum SG. Lithium Ion Batterieslithium-ion battery, Electrochemical Reactionslithium-ion batteryelectrochemical reactionsin. In: Meyers RA, editor. Encyclopedia of Sustainability Science and Technology. New York, NY: Springer New York; 2012. p. 6067-97.

[76] Arora P, Zhang Z. Battery Separators. Chemical Reviews. 2004;104:4419-62.

[77] Richardson DB. Electric vehicles and the electric grid: A review of modeling approaches, Impacts, and renewable energy integration. Renewable and Sustainable Energy Reviews. 2013;19:247-54.

[78] Martin G, Rentsch L, Höck M, Bertau M. Lithium market research - global supply, future demand and price development. Energy Storage Materials. 2017;6:171-9.

[79] Tadesse B, Makuei F, Albijanic B, Dyer L. The beneficiation of lithium minerals from hard rock ores: A review. Minerals Engineering. 2019;131:170-84.

[80] Jamasmie C. Lithium demand from battery makers to almost double by 2027. 2016.

[81] Sterba J, Krzemień A, Riesgo Fernández P, Escanciano García-Miranda C, Fidalgo Valverde G. Lithium mining: Accelerating the transition to sustainable energy. Resources Policy. 2019;62:416-26. 
[82] Bernhardt D, Reilly I. J. Mineral Commodity Summaries 2019. US Geological Survey, Reston, USA. 2019.

[83] Pehlken A, Albach S, Vogt T. Is there a resource constraint related to lithium ion batteries in cars? The International Journal of Life Cycle Assessment. 2015;22:40-53.

[84] Campagnol N, Eddy J, Hagenbruch T, Klip D, Mulligan C, van De Staaij J. Metal mining constraints on the electric mobility horizon. McKinsey \& Company. 2018.

[85] Kwade A, Haselrieder W, Leithoff R, Modlinger A, Dietrich F, Droeder K. Current status and challenges for automotive battery production technologies. Nature Energy. 2018;3:290-300.

[86] Schmuch R, Wagner R, Hörpel G, Placke T, Winter M. Performance and cost of materials for lithium-based rechargeable automotive batteries. Nature Energy. 2018;3:267-78.

[87] Mo JY, Jeon W. The Impact of Electric Vehicle Demand and Battery Recycling on Price Dynamics of Lithium-Ion Battery Cathode Materials: A Vector Error Correction Model (VECM) Analysis. Sustainability. 2018;10.

[88] Tisserant A, Pauliuk S. Matching global cobalt demand under different scenarios for co-production and mining attractiveness. Journal of Economic Structures. 2016;5:4.

[89] Hsieh IYL, Pan MS, Chiang Y-M, Green WH. Learning only buys you so much: Practical limits on battery price reduction. Applied Energy. 2019;239:218-24.

[90] Godwill E, Ferdinand P, Nwalo N, Unachukwu M. Mechanism and Health Effects of Heavy Metal Toxicity in Humans. 2019. p. 1-23.

[91] Thomas M. Research for TRAN Comittee - Battery-powered electric vehicles: market development and lifecycle emissions. 2018.

[92] Chagnes A, Pospiech B. A brief review on hydrometallurgical technologies for recycling spent lithium-ion batteries. Journal of Chemical Technology \& Biotechnology. 2013;88:1191-9.

[93] Zhao S, You F. Comparative Life-Cycle Assessment of Li-Ion Batteries through Process-Based and Integrated Hybrid Approaches. ACS Sustainable Chemistry \& Engineering. 2019;7:5082-94.

[94] Wang C, Chen B, Yu Y, Wang Y, Zhang W. Carbon footprint analysis of lithium ion secondary battery industry: two case studies from China. Journal of Cleaner Production. 2017;163:241-51. 
[95] Unterreiner L, Jülch V, Reith S. Recycling of Battery Technologies - Ecological Impact Analysis Using Life Cycle Assessment (LCA). Energy Procedia. 2016;99:22934.

[96] Morrow H. Eenvironmental and Human Health Impact Assessments of Battery Systems. Used Battery Collection and Recycling. 2001.

[97] Zackrisson M, Avellán L, Orlenius J. Life cycle assessment of lithium-ion batteries for plug-in hybrid electric vehicles - Critical issues. Journal of Cleaner Production. 2010;18:1519-29.

[98] Zackrisson M, Fransson K, Hildenbrand J, Lampic G, O'Dwyer C. Life cycle assessment of lithium-air battery cells. Journal of Cleaner Production. 2016;135:299311.

[99] Wanger TC. The Lithium future-resources, recycling, and the environment. Conservation Letters. 2011;4:202-6.

[100] Richa K, Babbitt CW, Gaustad G. Eco-Efficiency Analysis of a Lithium-Ion Battery Waste Hierarchy Inspired by Circular Economy. Journal of Industrial Ecology. 2017;21:715-30.

[101] Dunn JB, Gaines L, Sullivan J, Wang MQ. Impact of recycling on cradle-to-gate energy consumption and greenhouse gas emissions of automotive lithium-ion batteries. Environ Sci Technol. 2012;46:12704-10.

[102] Nguyen VT, Lee J-c, Jeong J, Kim B-S, Pandey BD. Selective recovery of cobalt, nickel and lithium from sulfate leachate of cathode scrap of Li-ion batteries using liquidliquid extraction. Metals and Materials International. 2014;20:357-65.

[103] da Cunha JM, Klein L, Bassaco MM, Tanabe EH, Bertuol DA, Dotto GL. Cobalt recovery from leached solutions of lithium-ion batteries using waste materials as adsorbents. The Canadian Journal of Chemical Engineering. 2015;93:2198-204.

[104] Lisbona D, Snee T. A review of hazards associated with primary lithium and lithium-ion batteries. Process Safety and Environmental Protection. 2011;89:434-42.

[105] Kang DH, Chen M, Ogunseitan OA. Potential environmental and human health impacts of rechargeable lithium batteries in electronic waste. Environ Sci Technol. 2013;47:5495-503.

[106] Bozich J, Hang M, Hamers R, Klaper R. Core chemistry influences the toxicity of multicomponent metal oxide nanomaterials, lithium nickel manganese cobalt oxide, and lithium cobalt oxide to Daphnia magna. Environ Toxicol Chem. 2017;36:2493-502. 
[107] Renault S, Brandell D, Edström K. Environmentally-Friendly Lithium Recycling From a Spent Organic Li-Ion Battery. ChemSusChem. 2014;7:2859-67.

[108] Gaines L. The future of automotive lithium-ion battery recycling: Charting a sustainable course. Sustainable Materials and Technologies. 2014;1-2:2-7.

[109] Wu D, Pan Y, Huang L, Zhou P, Quan X, Chen H. Complete separation of Cu(II), Co(II) and Li(I) using self-driven MFCs-MECs with stainless steel mesh cathodes under continuous flow conditions. Separation and Purification Technology. 2015;147:114-24. [110] Li L, Ge J, Chen R, Wu F, Chen S, Zhang X. Environmental friendly leaching reagent for cobalt and lithium recovery from spent lithium-ion batteries. Waste Management. 2010;30:2615-21.

[111] Yao L, Yao H, Xi G, Feng Y. Recycling and synthesis of LiNi1/3Co1/3Mn1/3O2 from waste lithium ion batteries using d,1-malic acid. RSC Advances. 2016;6:17947-54. [112] Perez E, Navarro Amador R, Carboni M, Meyer D. In-situ precipitation of MetalOrganic Frameworks from a simulant battery waste solution. Materials Letters. 2016;167:188-91.

[113] Abreu Gonçalves MC, Garcia EM, Taroco HA, Gorgulho HF, Melo JOF, Silva RRA, et al. Chemical recycling of cell phone Li-ion batteries: Application in environmental remediation. Waste Management. 2015;40:144-50.

[114] Zhao T, Yao Y, Wang M, Chen R, Yu Y, Wu F, et al. Preparation of MnO2Modified Graphite Sorbents from Spent Li-Ion Batteries for the Treatment of Water Contaminated by Lead, Cadmium, and Silver. ACS Appl Mater Interfaces. 2017;9:2536976.

[115] Hua Y, Zhou S, Huang Y, Liu X, Ling H, Zhou X, et al. Sustainable value chain of retired lithium-ion batteries for electric vehicles. Journal of Power Sources. 2020;478:228753.

[116] Busch J, Dawson D, Roelich K. Closing the low-carbon material loop using a dynamic whole system approach. Journal of Cleaner Production. 2017;149:751-61.

[117] Simon B, Weil M. Analysis of materials and energy flows of different lithium ion traction batteries. Revue de Métallurgie. 2013;110:65-76.

[118] Sabbaghi M, Esmaeilian B, Raihanian Mashhadi A, Cade W, Behdad S. Reusability Assessment of Lithium-Ion Laptop Batteries Based on Consumers Actual Usage Behavior2015.

[119] Management Association IR. Sustainable Infrastructure: Breakthroughs in Research and Practice: Breakthroughs in Research and Practice: IGI Global; 2019. 
[120] Diouf B, Pode R, Osei R. Recycling mobile phone batteries for lighting. Renewable Energy. 2015;78:509-15.

[121] Tytgat $\mathrm{J}$. The recycling efficiency of Li-ion EV batteries according to the European Commission regulation, and the relation with the end-of-life vehicles directive recycling rate. 2013 World Electric Vehicle Symposium and Exhibition (EVS27)2013. p. 1-9.

[122] Sommerville R, Zhu P, Rajaeifar MA, Heidrich O, Goodship V, Kendrick E. A qualitative assessment of lithium ion battery recycling processes. Resources, Conservation and Recycling. 2021;165:105219.

[123] Hoyer C, Kieckhäfer K, Spengler TS. Technology and capacity planning for the recycling of lithium-ion electric vehicle batteries in Germany. Journal of Business Economics. 2014;85:505-44.

[124] Vassura I, Morselli L, Bernardi E, Passarini F. Chemical characterisation of spent rechargeable batteries. Waste Manag. 2009;29:2332-5.

[125] Poyraz AS, Huang J, Cheng S, Bock DC, Wu L, Zhu Y, et al. Effective recycling of manganese oxide cathodes for lithium based batteries. Green Chemistry. 2016;18:3414-21.

[126] Sita LE, da Silva SP, da Silva PRC, Scarminio J. Re-synthesis of $\mathrm{LiCoO}_{2}$ extracted from spent Li-ion batteries with low and high state of health. Materials Chemistry and Physics. 2017;194:97-104.

[127] Granata G, Pagnanelli F, Moscardini E, Takacova Z, Havlik T, Toro L. Simultaneous recycling of nickel metal hydride, lithium ion and primary lithium batteries: Accomplishment of European Guidelines by optimizing mechanical pre-treatment and solvent extraction operations. Journal of Power Sources. 2012;212:205-11.

[128] Castillo S, Ansart F, Laberty-Robert C, Portal J. Advances in the recovering of spent lithium battery compounds. Journal of Power Sources. 2002;112:247-54.

[129] Asl NM, Cheah SS, Salim J, Kim Y. Lithium-liquid battery: harvesting lithium from waste Li-ion batteries and discharging with water. RSC Advances. 2012;2:6094-100. [130] Sangwan KS, Jindal A. An integrated fuzzy multi-criteria evaluation of lithium-ion battery recycling processes. International Journal of Sustainable Engineering. 2013;6:359-71.

[131] Bernardes AM, Espinosa DCR, Tenório JAS. Recycling of batteries: a review of current processes and technologies. Journal of Power Sources. 2004;130:291-8.

[132] Pindar S, Dhawan N. Rapid recycling of spent lithium-ion batteries using microwave route. Process Safety and Environmental Protection. 2021;147:226-33. 
[133] Zhang T, He Y, Ge L, Fu R, Zhang X, Huang Y. Characteristics of wet and dry crushing methods in the recycling process of spent lithium-ion batteries. Journal of Power Sources. 2013;240:766-71.

[134] Bae H, Hwang SM, Seo I, Kim Y. Electrochemical Lithium Recycling System toward Renewable and Sustainable Energy Technologies2016.

[135] Zhao S, Zhang W, Li G, Zhu H, Huang J, He W. Ultrasonic renovation mechanism of spent LCO batteries: A mild condition for cathode materials recycling. Resources, Conservation and Recycling. 2020;162:105019.

[136] Gao Y, Li Y, Li J, Xie H, Chen Y. Direct recovery of LiCoO2 from the recycled lithium-ion batteries via structure restoration. Journal of Alloys and Compounds. 2020;845:156234.

[137] Wang M, Tan Q, Liu L, Li J. Selective regeneration of lithium from spent lithiumion batteries using ionic substitution stimulated by mechanochemistry. Journal of Cleaner Production. 2021;279:123612.

[138] Lv H, Huang H, Huang C, Gao Q, Yang Z, Zhang W. Electric field driven delithiation: A strategy towards comprehensive and efficient recycling of electrode materials from spent lithium ion batteries. Applied Catalysis B: Environmental. 2021;283:119634.

[139] Tang Y, Qu X, Zhang B, Zhao Y, Xie H, Zhao J, et al. Recycling of spent lithium nickel cobalt manganese oxides via a low-temperature ammonium sulfation roasting approach. Journal of Cleaner Production. 2021;279:123633.

[140] Liu D, Su Z, Wang L. Pyrometallurgically regenerated LiMn2O4 cathode scrap material and its electrochemical properties. Ceramics International. 2021;47:42-7.

[141] Cai G, Fung KY, Ng KM, Wibowo C. Process Development for the Recycle of Spent Lithium Ion Batteries by Chemical Precipitation. Industrial \& Engineering Chemistry Research. 2014;53:18245-59.

[142] Hanisch C, Loellhoeffel T, Diekmann J, Markley KJ, Haselrieder W, Kwade A. Recycling of lithium-ion batteries: a novel method to separate coating and foil of electrodes. Journal of Cleaner Production. 2015;108:301-11.

[143] Iizuka A, Yamashita Y, Nagasawa H, Yamasaki A, Yanagisawa Y. Separation of lithium and cobalt from waste lithium-ion batteries via bipolar membrane electrodialysis coupled with chelation. Separation and Purification Technology. 2013;113:33-41. 
[144] Jang HD, Kim H, Chang H, Kim J, Roh KM, Choi J-H, et al. Aerosol-Assisted Extraction of Silicon Nanoparticles from Wafer Slicing Waste for Lithium Ion Batteries. Scientific Reports. 2015;5:9431.

[145] Jha AK, Jha MK, Kumari A, Sahu SK, Kumar V, Pandey BD. Selective separation and recovery of cobalt from leach liquor of discarded Li-ion batteries using thiophosphinic extractant. Separation and Purification Technology. 2013;104:160-6.

[146] Joo S-H, Shin S-M, Shin D-J, Wang J-P. Development of recycling technology to recover valuable metals from lithium primary and ion batteries. Proceedings of the Institution of Mechanical Engineers, Part B: Journal of Engineering Manufacture. 2015;229:212-20.

[147] Liu X, Li D, Bai S, Zhou H. Promotional recyclable Li-ion batteries by a magnetic binder with anti-vibration and non-fatigue performance. Journal of Materials Chemistry A. 2015;3:15403-7.

[148] Nayl AA, Elkhashab RA, Badawy SM, El-Khateeb MA. Acid leaching of mixed spent Li-ion batteries. Arabian Journal of Chemistry. 2017;10:S3632-S9.

[149] Olapiriyakul S, Caudill RJ. Thermodynamic Analysis to Assess the Environmental Impact of End-of-life Recovery Processing for Nanotechnology Products. Environmental Science \& Technology. 2009.

[150] Ou Z, Li J, Wang Z. Application of mechanochemistry to metal recovery from second-hand resources: a technical overview. Environ Sci Process Impacts. 2015; 17:1522-30.

[151] Guo F, Nishihama S, Yoshizuka K. Selective recovery of valuable metals from spent Li-ion batteries using solvent-impregnated resins2013.

[152] Guo Y, Li F, Zhu H, Li G, Huang J, He W. Leaching lithium from the anode electrode materials of spent lithium-ion batteries by hydrochloric acid $(\mathrm{HCl})$. Waste Management. 2015;51.

[153] Seon Hong H, Weon Kim D, Lack Choi H, Ryu S-S. Solvent Extraction of Co, Ni and Mn from NCM Sulfate Leaching Solution of Li(NCM)O2 Secondary Battery Scraps2017.

[154] Jha MK, Kumari A, Jha AK, Kumar V, Hait J, Pandey BD. Recovery of lithium and cobalt from waste lithium ion batteries of mobile phone. Waste Management. 2013;33:1890-7.

[155] Rothermel S, Evertz M, Kasnatscheew J, Qi X, Grützke M, Winter M, et al. Graphite Recycling from Spent Lithium Ion Batteries2016. 
[156] Ganter MJ, Landi BJ, Babbitt CW, Anctil A, Gaustad G. Cathode refunctionalization as a lithium ion battery recycling alternative. Journal of Power Sources. 2014;256:274-80.

[157] Shin S, Jung GJ, Lee WJ, Kang CY, Wang JP. Recovery Of Electrodic Powder From Spent Lithium Ion Batteries (LIBs)2015.

[158] Stehmann F, Jahnke S, Balmforth-Slater C, Scholl S. Adsorptive Exhaust Gas Cleaning for Recycling of Li-Ion-Batteries2017.

[159] Perez-Antolin D, Trócoli R, Palma J, Ventosa E. The injectable battery. A conceptually new strategy in pursue of a sustainable and circular battery model. Journal of Power Sources. 2020;480:228839.

[160] Sun L, Qiu K. Vacuum pyrolysis and hydrometallurgical process for the recovery of valuable metals from spent lithium-ion batteries. J Hazard Mater. 2011;194:378-84.

[161] Zeng X, Li J. Innovative application of ionic liquid to separate Al and cathode materials from spent high-power lithium-ion batteries. J Hazard Mater. 2014;271:50-6.

[162] Wang X, Gaustad G, Babbitt CW. Targeting high value metals in lithium-ion battery recycling via shredding and size-based separation. Waste Management. 2016;51:204-13.

[163] Pagnanelli F, Moscardini E, Altimari P, Abo Atia T, Toro L. Leaching of electrodic powders from lithium ion batteries: Optimization of operating conditions and effect of physical pretreatment for waste fraction retrieval. Waste Manag. 2017;60:706-15.

[164] Li J, Shi P, Wang Z, Chen Y, Chang CC. A combined recovery process of metals in spent lithium-ion batteries. Chemosphere. 2009;77:1132-6.

[165] Bai Y, Muralidharan N, Li J, Essehli R, Belharouak I. Sustainable Direct Recycling of Lithium-Ion Batteries via Solvent Recovery of Electrode Materials. ChemSusChem. 2020;13:5664-70.

[166] Swart P, Dewulf J, Biernaux A. Resource demand for the production of different cathode materials for lithium ion batteries. Journal of Cleaner Production. 2014;84:3919.

[167] Zhang R, Meng Z, Ma X, Chen M, Chen B, Zheng Y, et al. Understanding fundamental effects of $\mathrm{Cu}$ impurity in different forms for recovered LiNi0.6Co0.2Mn0.2O2 cathode materials. Nano Energy. 2020;78:105214.

[168] Zou H, Gratz E, Apelian D, Wang Y. A novel method to recycle mixed cathode materials for lithium ion batteries. Green Chemistry. 2013;15:1183. 
[169] Gao W, Zhang X, Zheng X, Lin X, Cao H, Zhang Y, et al. Lithium Carbonate Recovery from Cathode Scrap of Spent Lithium-Ion Battery: A Closed-Loop Process. Environmental Science \& Technology. 2017;51:1662-9.

[170] Gratz E, Sa Q, Apelian D, Wang Y. A closed loop process for recycling spent lithium ion batteries. Journal of Power Sources. 2014;262:255-62.

[171] Yan S, Sun C, Zhou T, Gao R, Xie H. Ultrasonic-assisted leaching of valuable metals from spent lithium-ion batteries using organic additives. Separation and Purification Technology. 2021;257:117930.

[172] Takacova Z, Havlik T, Kukurugya F, Orac D. Cobalt and lithium recovery from active mass of spent Li-ion batteries: Theoretical and experimental approach2016.

[173] Contestabile M, Panero S, Scrosati B. A laboratory-scale lithium-ion battery recycling process. Journal of Power Sources 2001;92:65-9.

[174] Chen X, Ma H, Luo C, Zhou T. Recovery of valuable metals from waste cathode materials of spent lithium-ion batteries using mild phosphoric acid. J Hazard Mater. 2017;326:77-86.

[175] Zeng X, Li J, Shen B. Novel approach to recover cobalt and lithium from spent lithium-ion battery using oxalic acid. J Hazard Mater. 2015;295:112-8.

[176] Meng Q, Zhang Y, Dong P. Use of glucose as reductant to recover Co from spent lithium ions batteries. Waste Manag. 2017;64:214-8.

[177] Wang F, Sun R, Xu J, Chen Z, Kang M. Recovery of cobalt from spent lithium ion batteries using sulphuric acid leaching followed by solid-liquid separation and solvent extraction. RSC Advances. 2016;6:85303-11.

[178] Pegoretti VCB, Dixini PVM, Smecellato PC, Biaggio SR, Freitas MBJG. Thermal synthesis, characterization and electrochemical study of high-temperature (HT) LiCoO 2 obtained from $\mathrm{Co}(\mathrm{OH}) 2$ recycled of spent lithium ion batteries. Materials Research Bulletin. 2017;86:5-9.

[179] Swain B, Jeong J, Lee J-c, Lee G-H, Sohn J-S. Hydrometallurgical process for recovery of cobalt from waste cathodic active material generated during manufacturing of lithium ion batteries. Journal of Power Sources. 2007;167:536-44.

[180] Nan J, Han D, Zuo X. Recovery of metal values from spent lithium-ion batteries with chemical deposition and solvent extraction. Journal of Power Sources. 2005; 152:278-84. 
[181] Park Y, Lim H, Moon J-H, Lee H-N, Son S, Kim H, et al. High-Yield One-Pot Recovery and Characterization of Nanostructured Cobalt Oxalate from Spent LithiumIon Batteries and Successive Re-Synthesis of LiCoO2. Metals. 2017;7:303.

[182] Swain B, Jeong J, Lee J-c, Lee G-H. Development of process flow sheet for recovery of high pure cobalt from sulfate leach liquor of LIB industry waste: A mathematical model correlation to predict optimum operational conditions. Separation and Purification Technology. 2008;63:360-9.

[183] Pagnanelli F, Moscardini E, Altimari P, Abo Atia T, Toro L. Cobalt products from real waste fractions of end of life lithium ion batteries. Waste Manag. 2016;51:214-21.

[184] Li L, Chen R, Sun F, Wu F, Liu J. Preparation of LiCoO2 films from spent lithiumion batteries by a combined recycling process. Hydrometallurgy. 2011;108:220-5.

[185] Li L, Ge J, Wu F, Chen R, Chen S, Wu B. Recovery of cobalt and lithium from spent lithium ion batteries using organic citric acid as leachant. J Hazard Mater. 2010; 176:288-93.

[186] Pant D, Dolker T. Green and facile method for the recovery of spent Lithium Nickel Manganese Cobalt Oxide (NMC) based Lithium ion batteries. Waste Manag. 2017;60:689-95.

[187] Nayaka GP, Pai KV, Manjanna J, Keny SJ. Use of mild organic acid reagents to recover the Co and Li from spent Li-ion batteries. Waste Management. 2016;51:234-8.

[188] Guan J, Li Y, Guo Y, Su R, Gao G, Song H, et al. Mechanochemical Process Enhanced Cobalt and Lithium Recycling from Wasted Lithium-Ion Batteries. ACS Sustainable Chemistry \& Engineering. 2017;5:1026-32.

[189] Li J, Zhao R, He X, Liu H. Preparation of LiCoO2 cathode materials from spent lithium-ion batteries. Ionics. 2008;15:111-3.

[190] Li L, Chen R, Zhang X, Wu F, Ge J, Xie M. Preparation and electrochemical properties of re-synthesized $\mathrm{LiCoO} 2$ from spent lithium-ion batteries. Chinese Science Bulletin. 2012;57:4188-94.

[191] Lu M, Zhang H, Wang B, Zheng X, Dai C. The Re-Synthesis of LiCoO2 from Spent Lithium Ion Batteries Separated by Vacuum-Assisted Heat-Treating Method2013.

[192] Kim D-S, Sohn J-S, Lee C-K, Lee J-H, Han K-S, Lee Y-I. Simultaneous separation and renovation of lithium cobalt oxide from the cathode of spent lithium ion rechargeable batteries. Journal of Power Sources. 2004;132:145-9.

[193] Wang M-M, Zhang C-C, Zhang F-S. Recycling of spent lithium-ion battery with polyvinyl chloride by mechanochemical process. Waste Management. 2017;67:232-9. 
[194] Zhang Z, He W, Li G, Xia J, Hu H, Huang J, et al. Recovery of Lithium Cobalt Oxide Material from the Cathode of Spent Lithium-Ion Batteries. ECS Electrochemistry Letters. 2014;3:A58-A61.

[195] Bertuol DA, Machado CM, Silva ML, Calgaro CO, Dotto GL, Tanabe EH. Recovery of cobalt from spent lithium-ion batteries using supercritical carbon dioxide extraction. Waste Manag. 2016;51:245-51.

[196] Freitas MBJG, Garcia EM. Electrochemical recycling of cobalt from cathodes of spent lithium-ion batteries. Journal of Power Sources. 2007;171:953-9.

[197] Hu X, Mousa E, Tian Y, Ye G. Recovery of Co, Ni, Mn, and Li from Li-ion batteries by smelting reduction - Part I: A laboratory-scale study. Journal of Power Sources. 2021;483:228936.

[198] Xu Y, Song D, Li L, An C, Wang Y, Jiao L, et al. A simple solvent method for the recovery of LixCoO2 and its applications in alkaline rechargeable batteries. Journal of Power Sources. 2014;252:286-91.

[199] Bertuol DA, Toniasso C, Jiménez BM, Meili L, Dotto GL, Tanabe EH, et al. Application of spouted bed elutriation in the recycling of lithium ion batteries. Journal of Power Sources. 2015;275:627-32.

[200] Zhang T, He Y, Wang F, Ge L, Zhu X, Li H. Chemical and process mineralogical characterizations of spent lithium-ion batteries: an approach by multi-analytical techniques. Waste Manag. 2014;34:1051-8.

[201] Sun L, Qiu K. Organic oxalate as leachant and precipitant for the recovery of valuable metals from spent lithium-ion batteries. Waste Management. 2012;32:1575-82. [202] He Y, Zhang T, Wang F, Zhang G, Zhang W, Wang J. Recovery of LiCoO2 and graphite from spent lithium-ion batteries by Fenton reagent-assisted flotation. Journal of Cleaner Production. 2017;143:319-25.

[203] Bian D, Sun Y, Li S, Tian Y, Yang Z, Fan X, et al. A novel process to recycle spent LiFePO 4 for synthesizing LiFePO 4 /C hierarchical microflowers. Electrochimica Acta. 2016;190:134-40.

[204] Kumar J, Shen X, Li B, Liu H, Zhao J. Selective recovery of Li and FePO4 from spent LiFePO4 cathode scraps by organic acids and the properties of the regenerated LiFePO4. Waste Management. 2020;113:32-40.

[205] Yadav P, Jie CJ, Tan S, Srinivasan M. Recycling of cathode from spent lithium iron phosphate batteries. Journal of Hazardous Materials. 2020;399:123068. 
[206] Kim HS, Shin EJ. Re-synthesis and Electrochemical Characteristics of LiFePO4Cathode Materials Recycled from Scrap Electrodes. Bulletin of the Korean Chemical Society. 2013;34:851-5.

[207] Shin EJ, Kim S, Noh J-K, Byun D, Chung KY, Kim H-S, et al. A green recycling process designed for LiFePO4 cathode materials for Li-ion batteries. Journal of Materials Chemistry A. 2015;3:11493-502.

[208] Zheng R, Zhao L, Wang W, Liu Y, Ma Q, Mu D, et al. Optimized Li and Fe recovery from spent lithium-ion batteries via solution-precipitation method 2016.

[209] Huang Y, Han G, Liu J, Chai W, Wang W, Yang S, et al. A stepwise recovery of metals from hybrid cathodes of spent Li-ion batteries with leaching-flotationprecipitation process. Journal of Power Sources. 2016;325:555-64.

[210] Li L, Fan E, Guan Y, Zhang X, Xue Q, Wei L, et al. Sustainable Recovery of Cathode Materials from Spent Lithium-Ion Batteries Using Lactic Acid Leaching System. ACS Sustainable Chemistry \& Engineering. 2017;5:5224-33.

[211] Zheng X, Gao W, Zhang X, He M, Lin X, Cao H, et al. Spent lithium-ion battery recycling - Reductive ammonia leaching of metals from cathode scrap by sodium sulphite. Waste Manag. 2017;60:680-8.

[212] Zhang X, Cao H, Xie Y, Ning P, An H, You H, et al. A closed-loop process for recycling $\mathrm{LiNi}_{1 / 3} \mathrm{Co}_{1 / 3} \mathrm{Mn}_{1 / 3} \mathrm{O}_{2}$ from the cathode scraps of lithium-ion batteries: Process optimization and kinetics analysis. Separation and Purification Technology. 2015;150:186-95.

[213] Kim S, Yang D, Rhee K, Sohn J. Recycling process of spent battery modules in used hybrid electric vehicles using physical/chemical treatments. Research on Chemical Intermediates. 2014;40:2447-56.

[214] Weng Y, Xu S, Huang G, Jiang C. Synthesis and performance of $\mathrm{Li}\left[\left(\mathrm{Ni}_{1 / 3} \mathrm{Co}_{1 / 3} \mathrm{Mn}_{1 / 3}\right)_{(1-\mathrm{x})} \mathrm{Mg}_{\mathrm{x}}\right] \mathrm{O}_{2}$ prepared from spent lithium ion batteries. J Hazard Mater. 2013;246-247:163-72.

[215] Liu Y, Liu M. Reproduction of Li battery $\mathrm{LiNi}_{\mathrm{x}} \mathrm{MnyCo}_{1-\mathrm{x}-\mathrm{y}} \mathrm{O}_{2}$ positive electrode material from the recycling of waste battery. International Journal of Hydrogen Energy. 2017;42:18189-95.

[216] Fu Y, He Y, Li J, Qu L, Yang Y, Guo X, et al. Improved hydrometallurgical extraction of valuable metals from spent lithium-ion batteries via a closed-loop process. Journal of Alloys and Compounds. 2020;847:156489. 
[217] Joulié M, Laucournet R, Billy E. Hydrometallurgical process for the recovery of high value metals from spent lithium nickel cobalt aluminum oxide based lithium-ion batteries. Journal of Power Sources. 2014;247:551-5.

[218] Chen X, Chen Y, Zhou T, Liu D, Hu H, Fan S. Hydrometallurgical recovery of metal values from sulfuric acid leaching liquor of spent lithium-ion batteries. Waste Management. 2015;38:349-56.

[219] Yao L, Feng Y, Xi Xi G. A new method for synthesis of LiNi1/3Co1/3Mn1/3O2 from waste lithium ion batteries2015.

[220] Zhang X, Xue Q, Li L, Fan E, Wu F, Chen R. Sustainable Recycling and Regeneration of Cathode Scraps from Industrial Production of Lithium-Ion Batteries. ACS Sustainable Chemistry \& Engineering. 2016;4:7041-9.

[221] Yang Y, Xu S, He Y. Lithium recycling and cathode material regeneration from acid leach liquor of spent lithium-ion battery via facile co-extraction and co-precipitation processes. Waste Manag. 2017;64:219-27.

[222] Hu J, Zhang J, Li H, Chen Y, Wang C. A promising approach for the recovery of high value-added metals from spent lithium-ion batteries. Journal of Power Sources. 2017;351:192-9.

[223] Ku H, Jung Y, Jo M, Park S, Kim S, Yang D, et al. Recycling of spent lithium-ion battery cathode materials by ammoniacal leaching. J Hazard Mater. 2016;313:138-46.

[224] Bahaloo-Horeh N, Mousavi SM. Enhanced recovery of valuable metals from spent lithium-ion batteries through optimization of organic acids produced by Aspergillus niger. Waste Manag. 2017;60:666-79.

[225] Barik SP, Prabaharan G, Kumar L. Leaching and separation of Co and Mn from electrode materials of spent lithium-ion batteries using hydrochloric acid: Laboratory and pilot scale study. Journal of Cleaner Production. 2017;147:37-43.

[226] Hu C, Guo J, Wen J, Peng Y. Preparation and Electrochemical Performance of Nano-Co3O4 Anode Materials from Spent Li-Ion Batteries for Lithium-Ion Batteries. Journal of Materials Science \& Technology. 2013;29:215-20.

[227] Kong L, Wang Y, Yu H, Liu B, Qi S, Wu D, et al. In-Situ Armoring: A Robust, High-Wettability and Fire-Resistant Hybrid Separator for Advanced and Safe Batteries. ACS Appl Mater Interfaces. 2018.

[228] Tanong K, Coudert L, Mercier G, Blais JF. Recovery of metals from a mixture of various spent batteries by a hydrometallurgical process. J Environ Manage. 2016;181:95107. 
[229] Pranolo Y, Zhang W, Cheng CY. Recovery of metals from spent lithium-ion battery leach solutions with a mixed solvent extractant system. Hydrometallurgy. 2010;102:3742.

[230] Wang H, Friedrich B. Development of a Highly Efficient Hydrometallurgical Recycling Process for Automotive Li-Ion Batteries. Journal of Sustainable Metallurgy. 2015;1:168-78.

[231] Swain B, Jeong J, Yoo K, Lee J-c. Synergistic separation of Co(II)/Li(I) for the recycling of LIB industry wastes by supported liquid membrane using Cyanex 272 and DR-8R2010.

[232] Yao L, Feng Y, Xi G. A new method for the synthesis of LiNi1/3Co1/3Mn1/3O2 from waste lithium ion batteries. RSC Advances. 2015;5:44107-14.

[233] Nie H, Xu L, Song D, Song J, Shi X, Wang X, et al. LiCoO2: recycling from spent batteries and regeneration with solid state synthesis. Green Chemistry. 2015;17:1276-80. [234] Ra D-i, Han K-S. Used lithium ion rechargeable battery recycling using EtoileRebatt technology. Journal of Power Sources. 2006;163:284-8.

[235] Barbieri EMS, Lima EPC, Lelis MFF, Freitas MBJG. Recycling of cobalt from spent $\mathrm{Li}$-ion batteries as $\beta-\mathrm{Co}(\mathrm{OH}) 2$ and the application of $\mathrm{Co} 3 \mathrm{O} 4$ as a pseudocapacitor. Journal of Power Sources. 2014;270:158-65.

[236] Barbieri EMS, Lima EPC, Cantarino SJ, Lelis MFF, Freitas MBJG. Recycling of spent ion-lithium batteries as cobalt hydroxide, and cobalt oxide films formed under a conductive glass substrate, and their electrochemical properties. Journal of Power Sources. 2014;269:158-63.

[237] Garcia EM, Tarôco HA, Matencio T, Domingues RZ, dos Santos JAF, Ferreira RV, et al. Electrochemical recycling of cobalt from spent cathodes of lithium-ion batteries: its application as supercapacitor. Journal of Applied Electrochemistry. 2012;42:361-6.

[238] Zheng R, Wang W, Dai Y, Ma Q, Liu Y, Mu D, et al. A closed-loop process for recycling LiNixCoyMn $(1-\mathrm{x}-\mathrm{y}) \mathrm{O} 2$ from mixed cathode materials of lithium-ion batteries. Green Energy \& Environment. 2017;2:42-50.

[239] Perez E, Andre M-L, Navarro Amador R, Hyvrard F, Borrini J, Carboni M, et al. Recovery of metals from simulant spent lithium-ion battery as organophosphonate coordination polymers in aqueous media. Journal of Hazardous Materials. 2016;317:617-21. 
[240] Guo X, Cao X, Huang G, Tian Q, Sun H. Recovery of lithium from the effluent obtained in the process of spent lithium-ion batteries recycling. $J$ Environ Manage. 2017;198:84-9.

[241] Chen X, Luo C, Zhang J, Kong J, Zhou T. Sustainable Recovery of Metals from Spent Lithium-Ion Batteries: A Green Process. ACS Sustainable Chemistry \& Engineering. 2015;3:3104-13.

[242] Song D, Xu Y, An C, Wang Q, Wang Y, Li L, et al. Recovered LiCoO2 as anode materials for Ni/Co power batteries. Phys Chem Chem Phys. 2012;14:71-5.

[243] Yu J, Wang X, Zhou M, Wang Q. A redox targeting-based material recycling strategy for spent lithium ion batteries. Energy \& Environmental Science. 2019;12:26727.

[244] Li X, Zhang J, Song D, Song J, Zhang L. Direct regeneration of recycled cathode material mixture from scrapped LiFePO 4 batteries. Journal of Power Sources. 2017;345:78-84.

[245] Chen J, Li Q, Song J, Song D, Zhang L, Shi X. Environmentally friendly recycling and effective repairing of cathode powders from spent LiFePO4 batteries. Green Chemistry. 2016;18:2500-6.

[246] Gies E. Recycling: Lazarus batteries. Nature. 2015;526:S100.

[247] Chen N, Qi J, Du X, Wang Y, Zhang W, Wang Y, et al. Recycled LiCoO2 in spent lithium-ion battery as an oxygen evolution electrocatalyst. RSC Advances. 2016;6:103541-5.

[248] Moura MN, Barrada RV, Almeida JR, Moreira TFM, Schettino MA, Freitas JCC, et al. Synthesis, characterization and photocatalytic properties of nanostructured $\mathrm{CoFe} 2 \mathrm{O} 4$ recycled from spent $\mathrm{Li}$-ion batteries. Chemosphere. 2017;182:339-47.

[249] Santana IL, Moreira TFM, Lelis MFF, Freitas MBJG. Photocatalytic properties of $\mathrm{Co} 3 \mathrm{O} 4 / \mathrm{LiCoO} 2$ recycled from spent lithium-ion batteries using citric acid as leaching agent. Materials Chemistry and Physics. 2017;190:38-44.

[250] Garcia EM, Tarôco HA, Matencio T, Domingues RZ, dos Santos JAF, de Freitas MBJG. Electrochemical recycling of cobalt from spent cathodes of lithium-ion batteries: its application as coating on SOFC interconnects. Journal of Applied Electrochemistry. 2011;41:1373-9.

[251] Garcia EM, Lins VdFC, Tarôco HA, Matencio T, Domingues RZ, dos Santos JAF. The anode environmentally friendly for water electrolysis based in $\mathrm{LiCoO} 2$ recycled from 
spent lithium-ion batteries. International Journal of Hydrogen Energy. 2012;37:167959.

[252] Guo Y, Zhao Y-L, Lou X, Zhou T, Wang Z, Fang C, et al. Efficient degradation of industrial pollutants with sulfur (IV) mediated by $\mathrm{LiCoO} 2$ cathode powders of spent lithium ion batteries: A "treating waste with waste" strategy. Journal of Hazardous Materials. 2020;399:123090.

[253] Zhao Y, Yuan X, Jiang L, Li X, Zhang J, Wang H. Reutilization of cathode material from spent batteries as a heterogeneous catalyst to remove antibiotics in wastewater via peroxymonosulfate activation. Chemical Engineering Journal. 2020;400:125903.

[254] Zou W, Feng X, Wang R, Wei W, Luo S, Zheng R, et al. High-efficiency core-shell magnetic heavy-metal absorbents derived from spent-LiFePO4 Battery. Journal of Hazardous Materials. 2021;402:123583.

[255] Guo M, Wang X, Liu L, Min X, Hu X, Guo W, et al. Recovery of cathode materials from spent lithium-ion batteries and their application in preparing multi-metal oxides for the removal of oxygenated VOCs: Effect of synthetic methods. Environmental Research. 2021;193:110563.

[256] Schauerman CM, Ganter MJ, Gaustad G, Babbitt CW, Raffaelle RP, Landi BJ. Recycling single-wall carbon nanotube anodes from lithium ion batteries. Journal of Materials Chemistry. 2012;22:12008.

[257] Chen B-H, Chang C-C, Duh J-G. Carbon-Assisted Technique to Modify the Surface of Recycled Silicon/Silicon Carbide Composite for Lithium-Ion Batteries. Energy Technology. 2017;5:1415-22.

[258] Chen B-H, Chuang S-I, Duh J-G. Double-plasma enhanced carbon shield for spatial/interfacial controlled electrodes in lithium ion batteries via micro-sized silicon from wafer waste. Journal of Power Sources. 2016;331:198-207.

[259] Tan H-G, Duh J-G. Processing silicon microparticles recycled from wafer waste via Rapid Thermal Process for lithium-ion battery anode materials. Journal of Power Sources. 2016;335:146-54.

[260] Jung DS, Ryou MH, Sung YJ, Park SB, Choi JW. Recycling rice husks for highcapacity lithium battery anodes. Proc Natl Acad Sci U S A. 2013;110:12229-34.

[261] Naskar AK, Bi Z, Li Y, Akato SK, Saha D, Chi M, et al. Tailored recovery of carbons from waste tires for enhanced performance as anodes in lithium-ion batteries. RSC Advances. 2014;4:38213. 
[262] Song D, Park J, Kim K, Lee LS, Seo JY, Oh Y-K, et al. Recycling oil-extracted microalgal biomass residues into nano/micro hierarchical $\mathrm{Sn} / \mathrm{C}$ composite anode materials for lithium-ion batteries. Electrochimica Acta. 2017;250:59-67.

[263] Take H, Kajii H, Yoshino K. Electrical and electrochemical properties of fly ash and effect of pyrolysis. Journal of Applied Physics. 2000;87:7316-9.

[264] Park S-W, Kim J-C, Dar MA, Shim H-W, Kim D-W. Enhanced cycle stability of silicon coated with waste poly(vinyl butyral)-directed carbon for lithium-ion battery anodes. Journal of Alloys and Compounds. 2017;698:525-31.

[265] Hou H, Yao Y, Liu S, Duan J, Liao Q, Yu C, et al. Recycled tetrahedron-like CuCl from waste $\mathrm{Cu}$ scraps for lithium ion battery anode. Waste Manag. 2017;65:147-52.

[266] Liu S, Hou H, Liu X, Duan J, Yao Y, Liao Q, et al. Recycled hierarchical tripodlike $\mathrm{CuCl}$ from $\mathrm{Cu}-\mathrm{PCB}$ waste etchant for lithium ion battery anode. J Hazard Mater. 2017;324:357-64.

[267] Yi C, Yang Y, Zhang T, Wu X, Sun W, Yi L. A green and facile approach for regeneration of graphite from spent lithium ion battery. Journal of Cleaner Production. 2020;277:123585.

[268] Cao N, Zhang Y, Chen L, Chu W, Huang Y, Jia Y, et al. An innovative approach to recover anode from spent lithium-ion battery. Journal of Power Sources. 2021;483:229163.

[269] Yu H, Dai H, Zhu Y, Hu H, Zhao R, Wu B, et al. Mechanistic insights into the lattice reconfiguration of the anode graphite recycled from spent high-power lithium-ion batteries. Journal of Power Sources. 2021;481:229159.

[270] Moradi B, Botte GG. Recycling of graphite anodes for the next generation of lithium ion batteries. Journal of Applied Electrochemistry. 2016;46:123-48.

[271] Jiao S, Lei H, Tu J, Zhu J, Wang J, Mao X. An industrialized prototype of the rechargeable $\mathrm{Al} / \mathrm{AlCl} 3$-[EMIm] Cl/graphite battery and recycling of the graphitic cathode into graphene. Carbon. 2016;109:276-81.

[272] Yu J, Lin M, Tan Q, Li J. High-value utilization of graphite electrodes in spent lithium-ion batteries: From 3D waste graphite to 2D graphene oxide. Journal of Hazardous Materials. 2021;401:123715.

[273] Liu Y, Mu D, Li R, Ma Q, Zheng R, Dai C. Purification and Characterization of Reclaimed Electrolytes from Spent Lithium-Ion Batteries. The Journal of Physical Chemistry C. 2017;121:4181-7. 
[274] Mu D, Liu Y, Li R, Ma Q, Dai C. Transcritical CO2 extraction of electrolytes for lithium-ion batteries: optimization of the recycling process and quality-quantity variation. New Journal of Chemistry. 2017;41:7177-85.

[275] Lain MJ. Recycling of lithium ion cells and batteries. Journal of Power Sources. 2001;97-98:736-8.

[276] Zhong X, Liu W, Han J, Jiao F, Zhu H, Qin W. Pneumatic separation for crushed spent lithium-ion batteries. Waste Management. 2020;118:331-40.

[277] Thomas J. Drive Cycle Powertrain Efficiencies and Trends Derived from EPA Vehicle Dynamometer Results. SAE International Journal of Passenger Cars Mechanical Systems. 2014;7:2014-01-562.

[278] Carlson RB, Wishart J, Stutenberg K. On-Road and Dynamometer Evaluation of Vehicle Auxiliary Loads. SAE International Journal of Fuels and Lubricants. 2016;9:2016-01-0901.

[279] Baglione M, Duty M, Pannone G. Vehicle System Energy Analysis Methodology and Tool for Determining Vehicle Subsystem Energy Supply and Demand. 2007.

[280] Crabtree G, Kocs E, Tillman B. Where is transportation going? Europhysics News. 2017;48:21-5.

[281] Golroudbary SR, Calisaya-Azpilcueta D, Kraslawski A. The Life Cycle of Energy Consumption and Greenhouse Gas Emissions from Critical Minerals Recycling: Case of Lithium-ion Batteries. 2017.

[282] Emilsson E, Dahllöf L. Lithium-Ion Vehicle Battery Production

Status 2019 on Energy Use, CO2 Emissions, Use of Metals, Products Environmental Footprint, and Recycling. 2019:316-21.

[283] Peters JF, Baumann M, Zimmermann B, Braun J, Weil M. The environmental impact of Li-Ion batteries and the role of key parameters - A review. Renewable and Sustainable Energy Reviews. 2017;67:491-506.

[284] Kim HC, Wallington TJ, Arsenault R, Bae C, Ahn S, Lee J. Cradle-to-Gate Emissions from a Commercial Electric Vehicle Li-Ion Battery: A Comparative Analysis. Environmental Science \& Technology. 2016;50:7715-22.

[285] Ellingsen LA-W, Singh B, Strømman AH. The size and range effect: lifecycle greenhouse gas emissions of electric vehicles. Environmental Research Letters. 2016;11:054010. 
[286] Ambrose H, Kendall A. Effects of battery chemistry and performance on the life cycle greenhouse gas intensity of electric mobility. Transportation Research Part D: Transport and Environment. 2016;47:182-94.

[287] Ellingsen LA-W, Majeau-Bettez G, Singh B, Srivastava AK, Valøen LO, Strømman AH. Life Cycle Assessment of a Lithium-Ion Battery Vehicle Pack. Journal of Industrial Ecology. 2014;18:113-24.

[288] Romare M, Dahllöf L. The Life Cycle Energy Consumption and Greenhouse Gas Emissions from Lithium-Ion Batteries. 2017.

[289] Logtenberg R, Pawley J, Saxifrage B. Comparing Fuel and Maintenance Costs of Electric and Gas Powered Vehicles in Canada. 2018.

[290] Jiao N. Second-life Electric Vehicle Batteries 2020-2030. 2019.

[291] Nissan. xStorage Home.

[292] Foster M, Isely P, Standridge CR, Hasan MM. Feasibility assessment of remanufacturing, repurposing, and recycling of end of vehicle application lithium-ion batteries. 2014. 2014;7:18.

[293] Foster M, Isely P, Standridge CR, Hasan MM. Feasibility assessment of remanufacturing, repurposing, and recycling of end of vehicle application lithium-ion batteries. Journal of Industrial Engineering and Management. 2014;7.

[294] Standridge CR, Hasan MM. Post-vehicle-application lithium-ion battery remanufacturing, repurposing and recycling capacity: Modeling and analysis. Journal of Industrial Engineering and Management. 2015;8.

[295] Bigum M, Brogaard L, Christensen TH. Metal recovery from high-grade WEEE: A life cycle assessment. Journal of Hazardous Materials. 2012;207-208:8-14.

[296] Kushnir D. Lithium Ion Battery Recycling Technology 2015: Current State and Future Prospects. Environmental Systems Analysis. 2015.

[297] Träger T, Friedrich B, Weyhe R. Recovery Concept of Value Metals from Automotive Lithium-Ion Batteries. Chemie Ingenieur Technik. 2015;87:1550-7.

[298] Ahmadi L, Young SB, Fowler M, Fraser RA, Achachlouei MA. A cascaded life cycle: reuse of electric vehicle lithium-ion battery packs in energy storage systems. The International Journal of Life Cycle Assessment. 2015;22:111-24. 